\title{
Mutational biosynthesis of hitachimycin analogs controlled by the $\beta$-amino acid-selective adenylation enzyme HitB
}

Fumitaka Kudo, ${ }^{1, *}$ Sotaro Takahashi, ${ }^{1}$ Akimasa Miyanaga, ${ }^{1}$ Yuichiro Nakazawa, ${ }^{1}$ Kota Nishino, ${ }^{1}$

Yuki Hayakawa, ${ }^{1}$ Koichi Kawamura, ${ }^{1}$ Fumihiro Ishikawa, ${ }^{2}$ Genzoh Tanabe, ${ }^{2}$ Naeko Iwai, ${ }^{3}$ Yoko Nagumo, ${ }^{3}$ Takeo Usui, ${ }^{3}$ Tadashi Eguchi ${ }^{1, *}$

${ }^{1}$ Department of Chemistry, Tokyo Institute of Technology, 2-12-1 Meguro-ku, O-okayama, Tokyo 152-8551, Japan.

${ }^{2}$ Faculty of Pharmacy, Kindai University, 3-4-1 Kowakae, Higashi-Osaka, Osaka 577-8502, Japan.

${ }^{3}$ Graduate School of Life and Environmental Sciences, University of Tsukuba, 1-1-1 Tennodai, Tsukuba 305-8572, Ibaraki, Japan. 


\section{List of Supporting Information}

\section{Supporting method}

Synthesis of 5'-O-[N-(3S- $\beta$-3-bromophenylalanyl)sulfamoyl]adenosine ( $\beta-m$-Br-Phe-SA).

Scheme S1. A proposed biosynthetic pathway for hitachimycin.

Figure S1-1 4. NMR spectra $\left({ }^{1} \mathrm{H}, \mathrm{COSY},{ }^{13} \mathrm{C}\right.$, and HMQC) of natural type hitachimycin (H-1).

Figure S2-1 5. NMR spectra $\left({ }^{1} \mathrm{H}, \mathrm{COSY},{ }^{13} \mathrm{C}, \mathrm{HMQC}\right.$, and HMBC) of $o$-F-phenyl hitachimycin (H-2).

Figure S3-1 3. NMR spectra $\left({ }^{1} \mathrm{H}, \mathrm{COSY}\right.$, and $\left.{ }^{13} \mathrm{C}\right)$ of $m$-F-phenyl hitachimycin $(\mathbf{H - 3})$.

Figure S4-1 5. NMR spectra $\left({ }^{1} \mathrm{H}, \mathrm{COSY},{ }^{13} \mathrm{C}, \mathrm{HMQC}\right.$, and HMBC) of $p$-F-phenyl hitachimycin (H-4).

Figure S5-1 4. NMR spectra $\left({ }^{1} \mathrm{H}, \mathrm{COSY},{ }^{13} \mathrm{C}\right.$, and HMQC) of $m$-Cl-phenyl hitachimycin (H-5).

Figure S6-1 4. NMR spectra $\left({ }^{1} \mathrm{H}, \mathrm{COSY},{ }^{13} \mathrm{C}\right.$, and HMQC) of $m$-Br-phenyl hitachimycin (H-6).

Figure S7-1 3. NMR spectra $\left({ }^{1} \mathrm{H}, \mathrm{COSY}\right.$, and $\left.{ }^{13} \mathrm{C}\right)$ of $m$-Me-phenyl hitachimycin $(\mathbf{H}-7)$.

Figure S8-1 4. NMR spectra $\left({ }^{1} \mathrm{H}, \mathrm{COSY},{ }^{13} \mathrm{C}\right.$, and HMQC) of 3-thienyl hitachimycin (H-8).

Figure S9-1 4. NMR spectra $\left({ }^{1} \mathrm{H}, \mathrm{COSY},{ }^{13} \mathrm{C}\right.$, and HMQC) of 2-thienyl hitachimycin (H-9).

Figure S10. Dimeric structure of HitB.

Figure S11. Structures of HitB monomer.

Figure S12. Adenosine binding site of HitB.

Figure S13. Structural comparison of the active site of HitB with those of other adenylation enzymes.

Figure S14. Comparison of the HitB active site structures.

Figure S15. NMR spectra of $(S)-m$-Br- $\beta$-Phe-SA (in $\mathrm{CD}_{3} \mathrm{OD}$ ). A) ${ }^{1} \mathrm{H}-\mathrm{NMR}$. B) ${ }^{13} \mathrm{C}-\mathrm{NMR}$.

Table S1. NMR data of hitachimycin (H-1) (natural type).

Table S2. NMR data of $o$-F-phenyl hitachimycin (H-2).

Table S3. NMR data of $m$-F-phenyl hitachimycin (H-3).

Table S4. NMR data of $p$-F-phenyl hitachimycin (H-4).

Table S5. NMR data of $m$-Cl-phenyl hitachimycin (H-5).

Table S6. NMR data of $m$-Br-phenyl hitachimycin (H-6).

Table S7. NMR data of $m$-Me-phenyl hitachimycin (H-7).

Table S8. NMR data of 3-thienyl hitachimycin (H-8).

Table S9. NMR data of 2-thienyl hitachimycin (H-9).

Table S10. NMR data of $(S)-m$-Br- $\beta$-Phe-SA.

Table S11. Structural data collection and refinement statistics. 


\section{Supporting method}

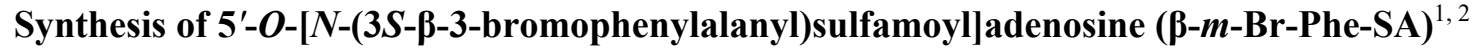
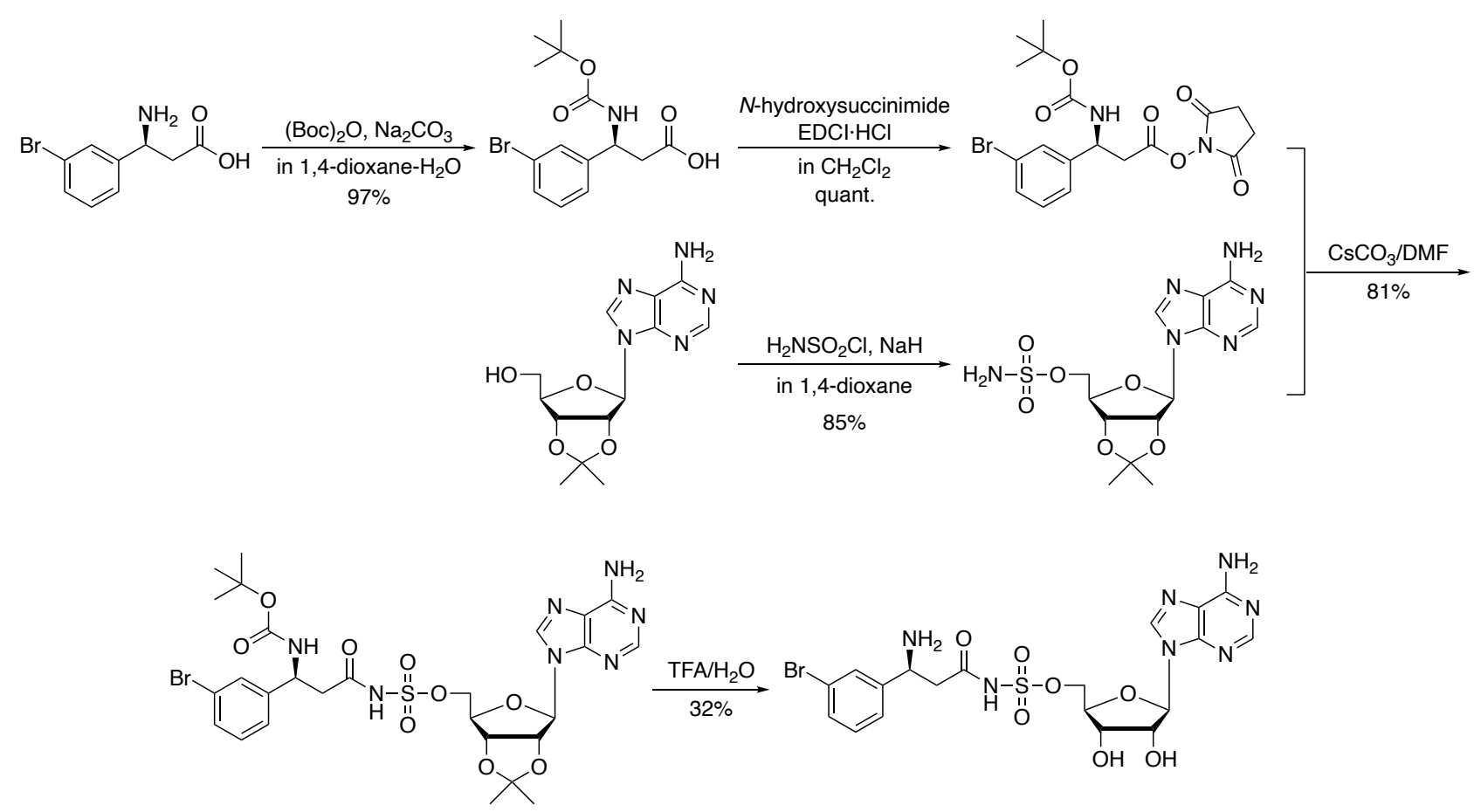

To a solution of chlorosulfonyl isocyanate $(1.5 \mathrm{~mL}, 17.3 \mathrm{mmol}$, TCI $)$ in dichloromethane $(3.5 \mathrm{~mL})$ was added solution of formic acid $(0.66 \mathrm{~mL}, 17.3 \mathrm{mmol})$ in dichloromethane $(3.5 \mathrm{~mL})$ dropwise over $10 \mathrm{~min}$ at $0{ }^{\circ} \mathrm{C}$. The mixture was stirred for additional $10 \mathrm{~min}$ at $0{ }^{\circ} \mathrm{C}$. The apparatus was removed from the ice bath and the white suspension was stirred for $12 \mathrm{~h}$ at room temperature. The flask was then placed in a freezer at $-30{ }^{\circ} \mathrm{C}$ for $6 \mathrm{~h}$. The cold dichloromethane supernatant was removed and resulting white solid was dried in vacuo to yield sulfamoyl chloride (780 mg, 35\%). This material was used in the next step without further purification.

To a magnetically stirred solution of $\mathrm{NaH}$ ( $65 \mathrm{mg}$ of a $55 \%$ suspension in mineral oil, $1.5 \mathrm{mmol}$ ) in 1,4-dioxane $\left(20 \mathrm{~mL}\right.$, Super Dehydrated, FUJIFILM Wako) under $\mathrm{N}_{2}$ at $0{ }^{\circ} \mathrm{C}$ was added 2',3'-Oisopropylideneadenosine $(309 \mathrm{mg}, 1 \mathrm{mmol}, \mathrm{TCI})$. The mixture was stirred for additional $30 \mathrm{~min}$ at $0{ }^{\circ} \mathrm{C}$. Sulfamoyl chloride (190 mg, $1.5 \mathrm{mmol}$ ) in 1,4-dioxane (2 mL, Super Dehydrated) was added dropwise and the mixture was stirred for $30 \mathrm{~min}$ at $0{ }^{\circ} \mathrm{C}$ and for additional $5 \mathrm{~h}$ at room temperature. Reaction was quenched with methanol and the resulting solution was passed through a celite pad. The obtained solution was evaporated to remove the solvents. The resultant residue $(504 \mathrm{mg})$ was purified by silica-gel chromatography $\left(\mathrm{CHCl}_{3}: \mathrm{CH}_{3} \mathrm{OH}=9: 1, \mathrm{v} / \mathrm{v}\right)$ to yield 2',3'-O-isopropylidene-5'-O-sulfamoyladenosine (330 mg, 85\%).

To a mixture of (S)- $\beta$ - $m$-Br-Phe (150 mg, $0.6 \mathrm{mmol})$ and sodium bicarbonate (194 mg, $1.8 \mathrm{mmol})$ in water (10 $\mathrm{mL})$ and 1,4-dioxane $(10 \mathrm{~mL})$ was added dropwise di-tert-butyl decarbonate $(200 \mathrm{mg}, 0.9 \mathrm{mmol})$ at $0{ }^{\circ} \mathrm{C}$. The mixture was stirred at room temperature for $44 \mathrm{~h}$. The resulting mixture was filtered and the filtrate was adjusted to $\mathrm{pH} 4.0$ with aqueous $\mathrm{HCl}$. The residue was extracted with dichloromethane three times and the 
combined organic layers was dried over sodium sulfate and concentrated in vacuo to give $N$-Boc- $(S)-\beta-m$-BrPhe (204 mg, 97\%).

$N$-Boc-(S)- $\beta$ - $m$-Br-Phe (100 mg, $0.3 \mathrm{mmol}), N$-hydroxysuccinimide (41 mg, $0.36 \mathrm{mmol})$, and 1-(3dimethylaminopropyl)-3-ethylcarbodiimide hydrochloride (EDCI $\cdot \mathrm{HCl}, 43 \mathrm{mg}, 0.36 \mathrm{mmol}$ ) were dissolved in dichloromethane ( $3 \mathrm{~mL}$, Super Dehydrated, FUJIFILM Wako) and the mixture was stirred at room temperature for $4 \mathrm{~h}$. Reaction was quenched with water and the resulting solution extracted with dichloromethane three times and the combined organic layers was dried over sodium sulfate and concentrated in vacuo to give $\mathrm{N}$ Boc- $(S)-\beta-m$-Br-Phe $N$-hydroxysuccinimide ester as white solid $(143 \mathrm{mg}, 0.3 \mathrm{mmol})$. This material was used in the next step without further purification.

$N$-Boc- $(S)-\beta-m$-Br-Phe $N$-hydroxysuccinimide ester as white solid (143 mg, $0.3 \mathrm{mmol}), 2^{\prime}, 3^{\prime}-O$ isopropylidene-5'- $O$-sulfamoyladenosine ( $116 \mathrm{mg}, 0.3 \mathrm{mmol}$ ), and cesium carbonate ( $116 \mathrm{mg}, 0.33 \mathrm{~mol})$ were dissolved in $N, N$-dimethylformamide ( $3 \mathrm{~mL}$, Super Dehydrated, FUJIFILM Wako) and the mixture was stirred at room temperature for $14 \mathrm{~h}$. The solution was then concentrated in vacuo to give the crude residue, which was purified by silica-gel chromatography $\left(\mathrm{CHCl}_{3}: \mathrm{CH}_{3} \mathrm{OH}=10: 1, \mathrm{v} / \mathrm{v}, \mathrm{Rf} 0.33\right)$ to yield $2^{\prime}, 3^{\prime}-O-$

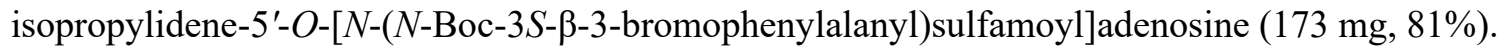

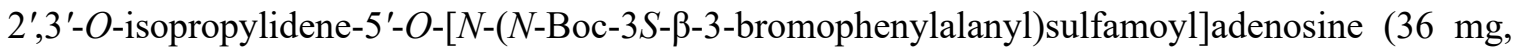
$0.05 \mathrm{mmol}$ ) was dissolved in $42 \mu \mathrm{l}$ of water and $208 \mu \mathrm{l}$ of trifluoroacetic acid. The mixture was stirred at room temperature for $3 \mathrm{~h}$. The solution was then concentrated in vacuo to give the crude residue $(58 \mathrm{mg})$, which was purified by silica-gel chromatography $\left(\mathrm{CHCl}_{3}: \mathrm{CH}_{3} \mathrm{OH}=7: 3\right.$ with $1 \%$ triethylamine $)$ to yield $5^{\prime}-O-[N-(3 S-\beta-3-$ bromophenylalanyl)sulfamoyl]adenosine (9.1 mg, 32\%). NMR data were described below (Figure S14 and Table S10). HRFABMS (glycerol as matrix, positive mode): $[\mathrm{M}+\mathrm{H}]^{+}$at $\mathrm{m} / \mathrm{z} 572.0574$ (calcd $[\mathrm{M}+\mathrm{H}]^{+}$ion for $\mathrm{C}_{19} \mathrm{H}_{23}{ }^{79} \mathrm{BrN}_{7} \mathrm{O}_{7} \mathrm{~S}$ at $m / z$ 572.0563).

(S)- $\beta$-Phe-SA was also synthesized according to literature procedures. ${ }^{1}$

\section{References}

(1) Niquille, D. L., Hansen, D. A., Mori, T., Fercher, D., Kries, H., and Hilvert, D. (2018) Nonribosomal biosynthesis of backbone-modified peptides, Nat. Chem. 10, 282-287.

(2) Ishikawa, F., Miyanaga, A., Kitayama, H., Nakamura, S., Nakanishi, I., Kudo, F., Eguchi, T., and Tanabe, G. (2019) An engineered aryl acid adenylation domain with an enlarged substrate binding pocket, Angew. Chem. Int. Ed. 58, 6906-6910. 
Scheme S1. A proposed biosynthetic pathway for hitachimycin

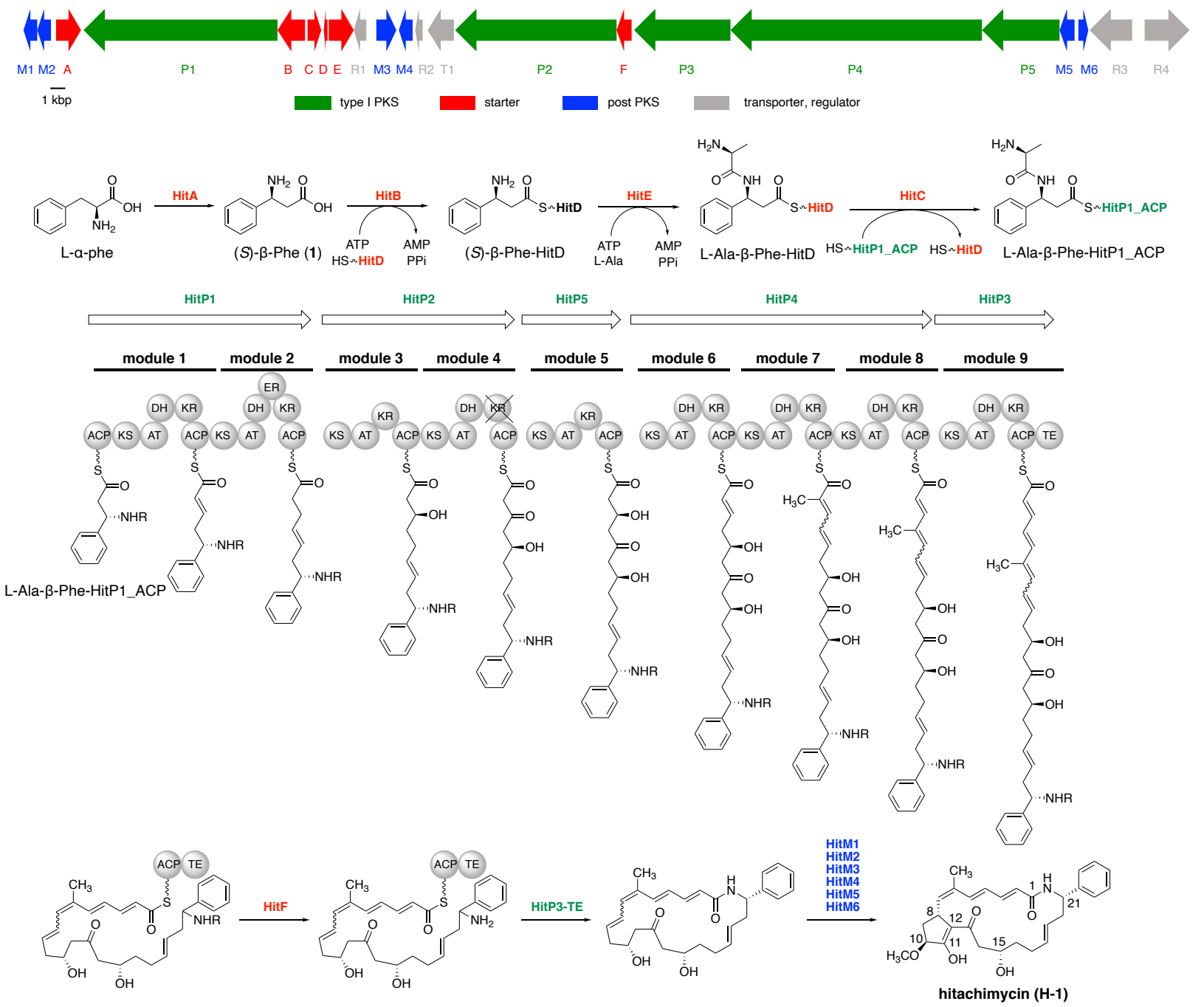

Putative functions of the hitachimycin biosynthetic (hit) genes.

\begin{tabular}{|c|c|c|c|}
\hline Gene & Size in bp (AA) & Putative functions & $\begin{array}{l}\text { Homologs from vin, cmi, and idn cluster }{ }^{[\mathrm{b}]} \\
\text { (except for PKS) }\end{array}$ \\
\hline hitM1 & $870(290)$ & Short-chain dehydrogenase & cmiM1 \\
\hline hitM2 & $864(288)$ & Sugar phosphate isomerase/epimerase & cmiM2 \\
\hline hitA & $1551(517)$ & Phenylalanine-2,3-aminomutase & \\
\hline hitP1 & $11949(3983)$ & PKS (ACP-KS-AT-DH-KR-ACP-KS-AT-DH-ER-KR-ACP) & \\
\hline hitB & $1599(533)$ & ATP-dependent $\beta$-aminoacyl-ACP synthetase & $\operatorname{vinN}, c m i S 6, i d n L 1$ \\
\hline hitc & $945(315)$ & ACP aminoacyltransferase & vinK, cmiS5, idnL2 \\
\hline hitD & $246(82)$ & ACP & vinL, cmiS4, idnL6 \\
\hline hitE & $1548(516)$ & ATP-dependent aminoacyl-ACP synthetase & vinM, cmiS3, idnL7 \\
\hline hitR1 & $720(240)$ & TetR family transcriptional regulator & \\
\hline hitM3 & $1236(412)$ & Cytochrome P450 monooxygenase & cmiM4 \\
\hline hitM4 & $864(288)$ & 3-ketoacyl-ACP reductase & cmiM3 \\
\hline hitR2 & $435(145)$ & Hypothetical protein & \\
\hline hitT1 & $1614(538)$ & MFS transporter & \\
\hline hitP2 & $9975(3325)$ & PKS (KS-AT-KR-ACP-KS-AT-DH-KR ${ }^{[a]-A C P)}$ & \\
\hline hitF & $906(302)$ & Amidohydrolase & vinJ, cmiM6, idnL5 \\
\hline hitP3 & $6012(2004)$ & PKS (KS-AT-DH-KR-ACP-TE) & \\
\hline hitP4 & $15558(5186)$ & PKS (KS-AT-DH-KR-ACP-KS-AT-DH-KR-ACP-KS-AT-DH-KR-ACP) & \\
\hline hitP5 & $4836(1612)$ & PKS (KS-AT-KR-ACP) & \\
\hline hitM5 & $903(301)$ & Sugar phosphate isomerase/epimerase & cmiM7 \\
\hline hitM6 & $651(217)$ & O-methyltransferase & \\
\hline hitR3 & $2652(884)$ & LuxR-family transcriptional regulator & cmiR5 \\
\hline hitR4 & $2802(934)$ & LuxR-family transcriptional regulator & \\
\hline
\end{tabular}

[a] This KR domain appeared to be inactive due to the lack of a catalytic tyrosine residue and NADPH binding motif. [b] vin; vicenistatin biosynthetic gene, cmi; cremimycin biosynthetic gene, and idn; incednine biosynthetic gene.

PKS; polyketide synthase, ACP; acyl carrier protein, KS; $\beta$-ketosynthase, AT; acyltransferase, DH; dehydratase, ER; enoylreductase, KR; $\beta$-ketoreductase, TE; thioesterase, ATP; adenosine triphosphate. 
Figure S1-1. ${ }^{1} \mathrm{H}$ NMR spectra of natural type hitachimycin $(\mathbf{H}-1)\left(500 \mathrm{MHz}\right.$, in $\left.\mathrm{CDCl}_{3}+\mathrm{CD}_{3} \mathrm{OD}\right)$.

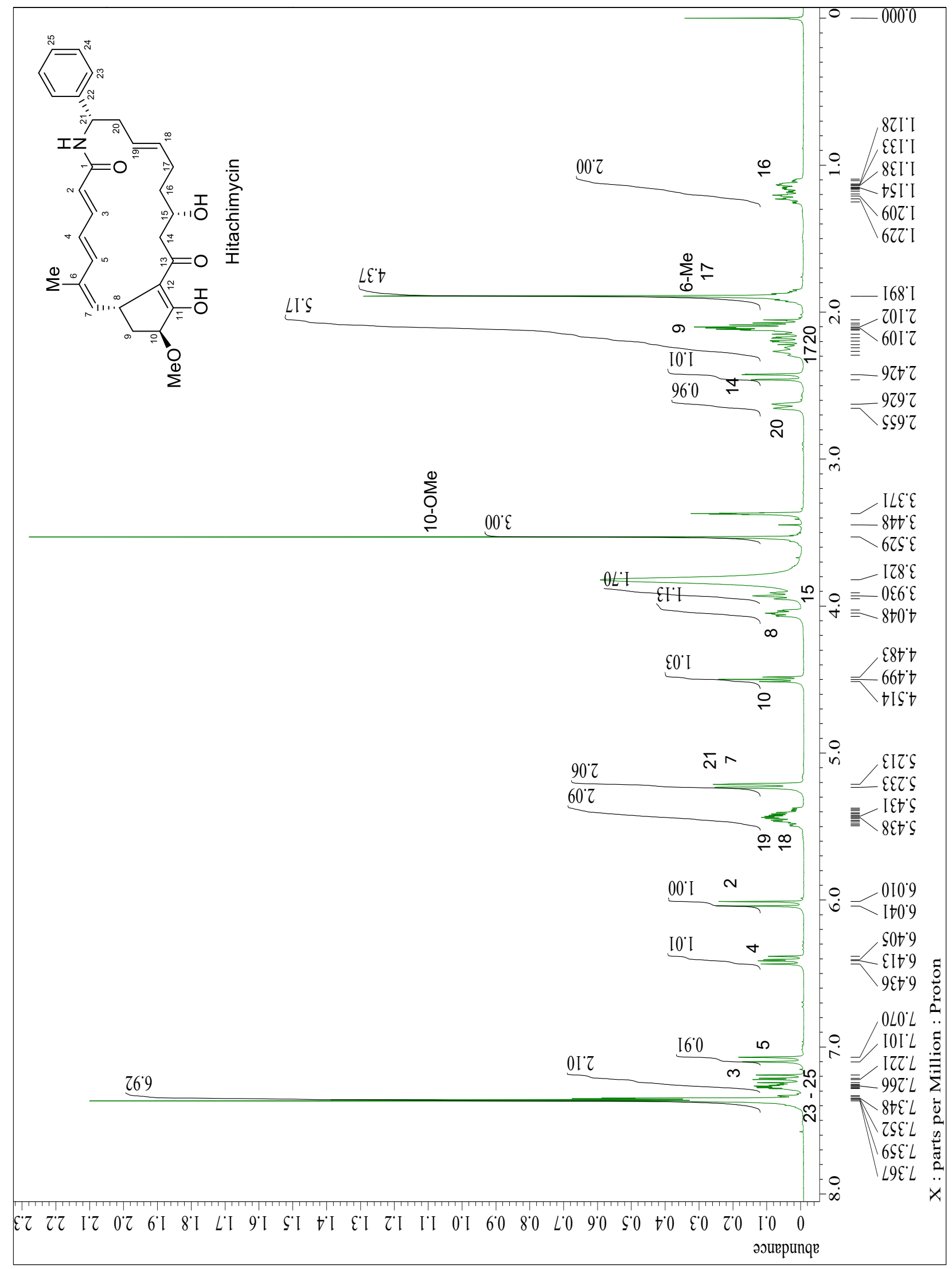


Figure S1-2. ${ }^{1} \mathrm{H}-{ }^{1} \mathrm{H}$ COSY of natural type hitachimycin (H-1) (in $\left.\mathrm{CDCl}_{3}+\mathrm{CD}_{3} \mathrm{OD}\right)$.

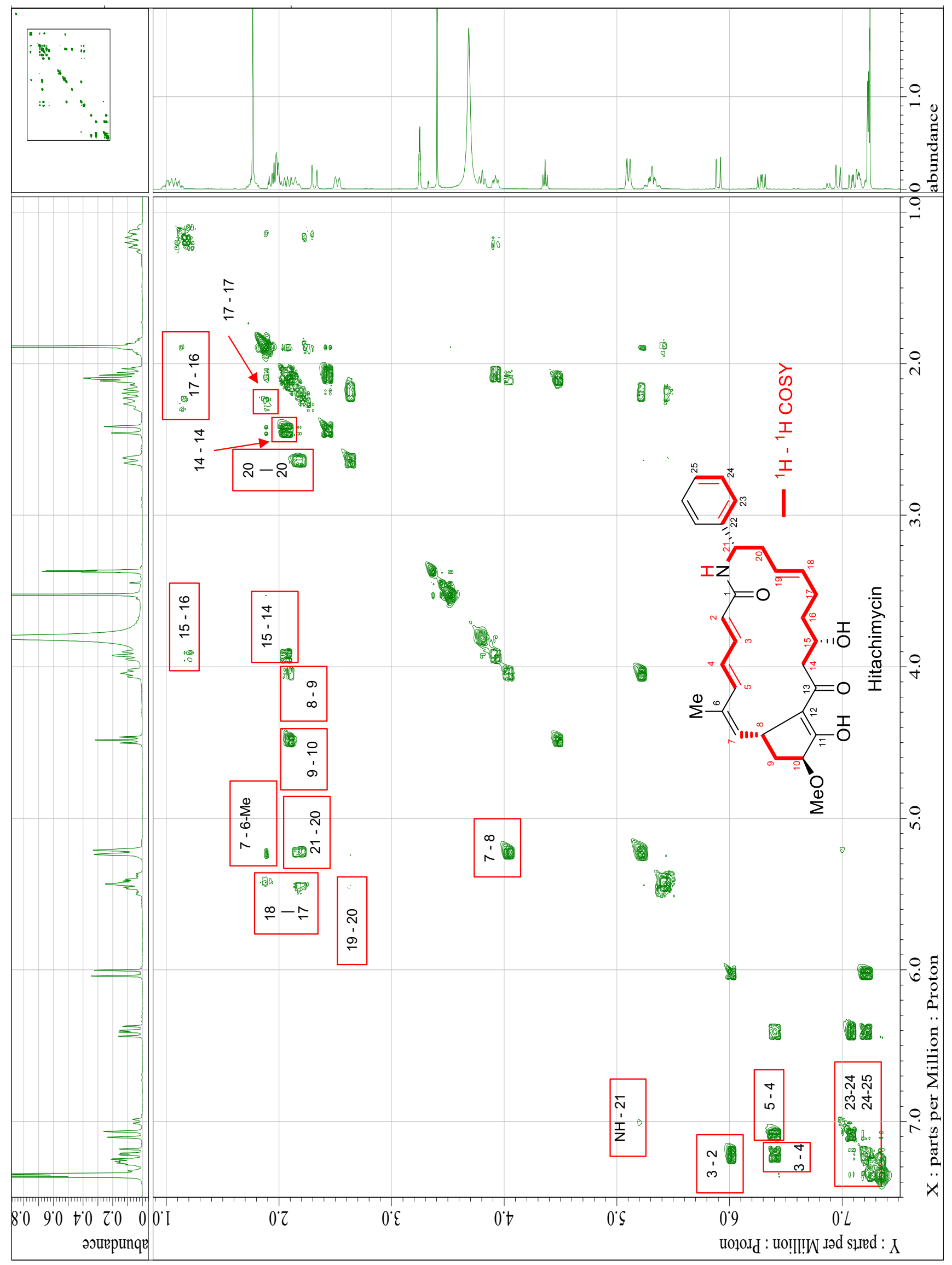


Figure S1-3. ${ }^{13} \mathrm{C}$ NMR spectra of natural type hitachimycin $(\mathbf{H}-1)\left(500 \mathrm{MHz}\right.$, in $\left.\mathrm{CDCl}_{3}+\mathrm{CD}_{3} \mathrm{OD}\right)$.

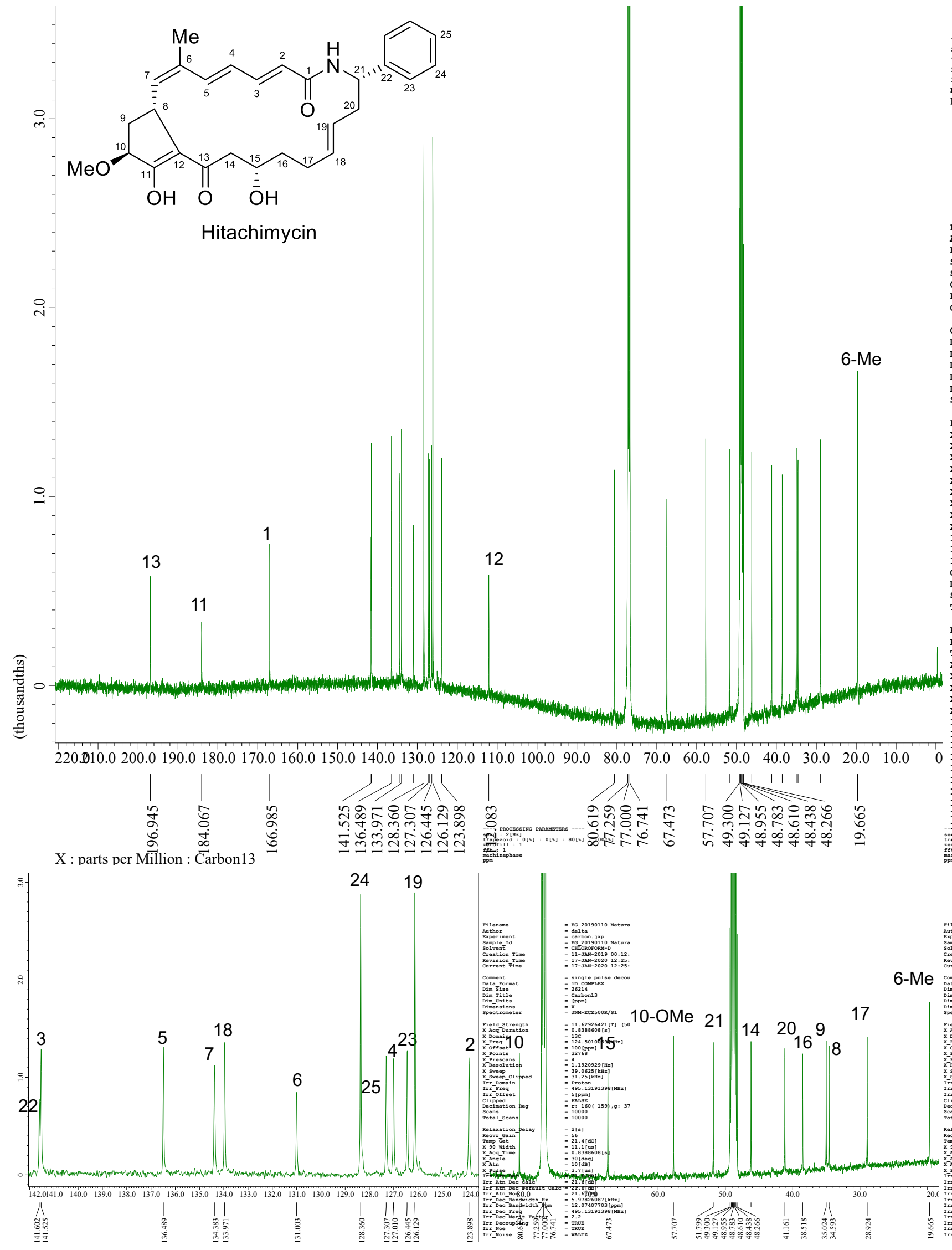


Figure S1-4. HMQC of natural type hitachimycin (H-1) (in $\left.\mathrm{CDCl}_{3}+\mathrm{CD}_{3} \mathrm{OD}\right)$.

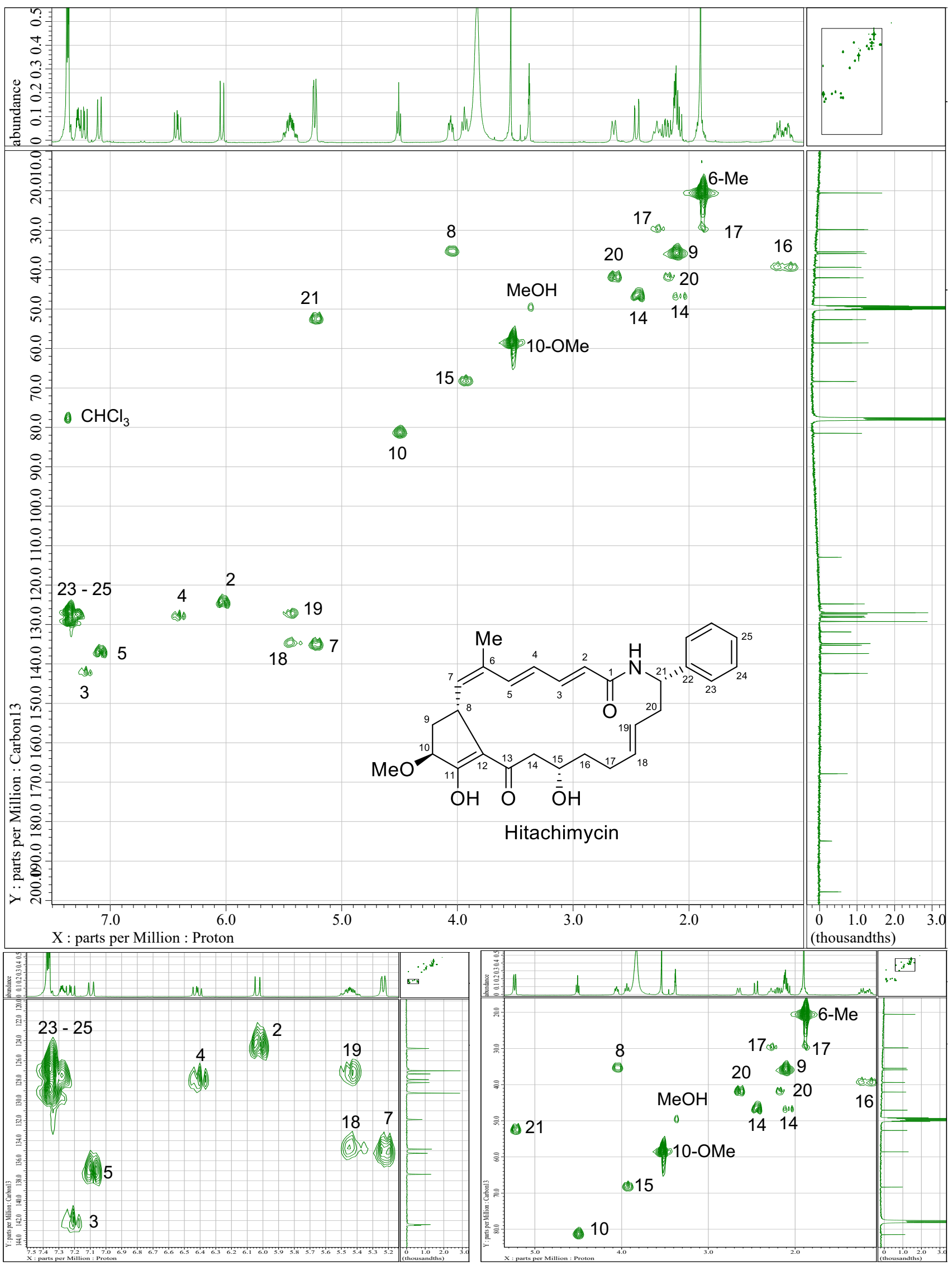


Figure S2-1. ${ }^{1} \mathrm{H}$ NMR spectra of $o$-F-phenyl hitachimycin $(\mathbf{H}-2)\left(400 \mathrm{MHz}\right.$, in $\left.\mathrm{CDCl}_{3}+\mathrm{CD}_{3} \mathrm{OD}\right)$.
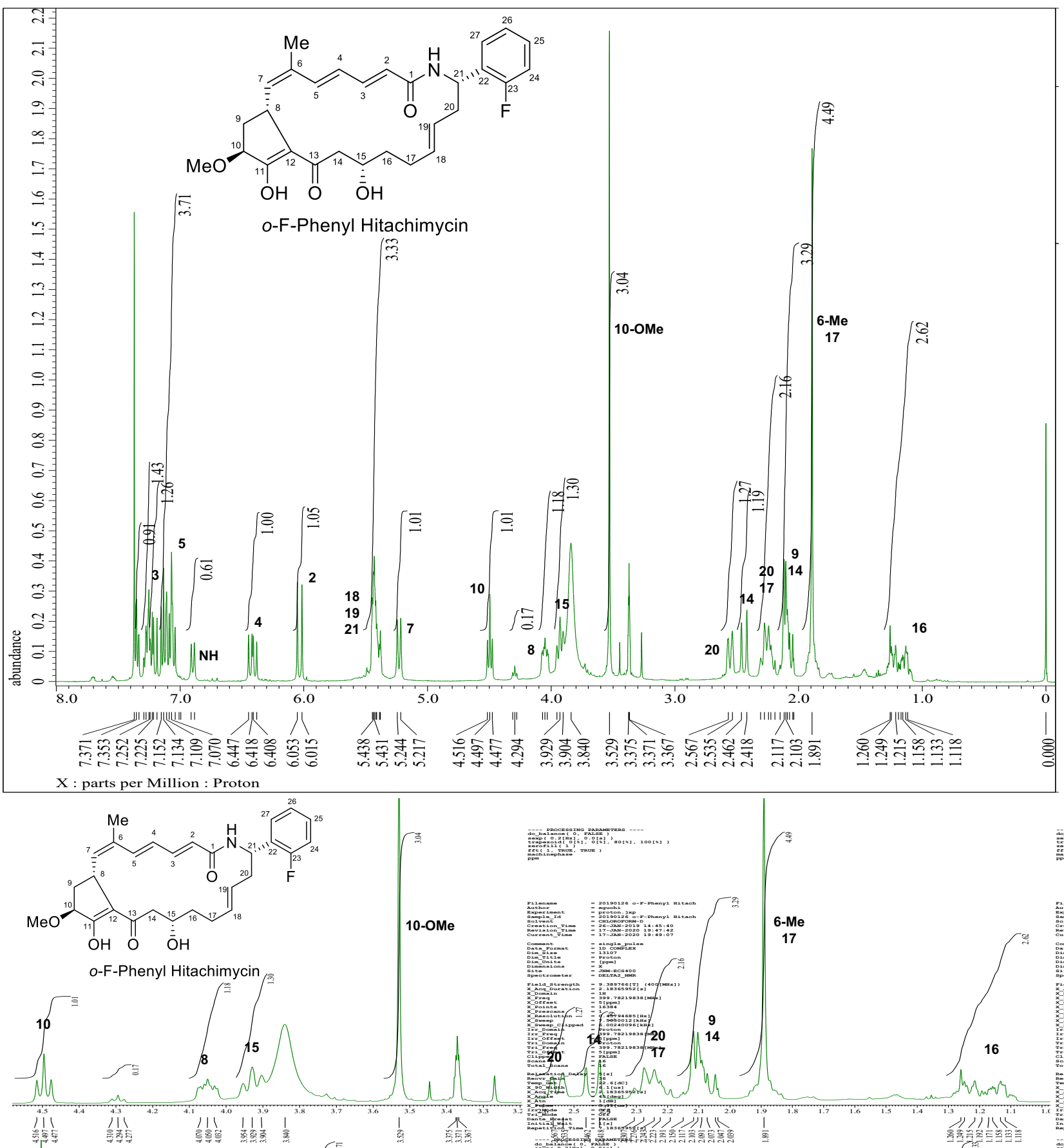

17

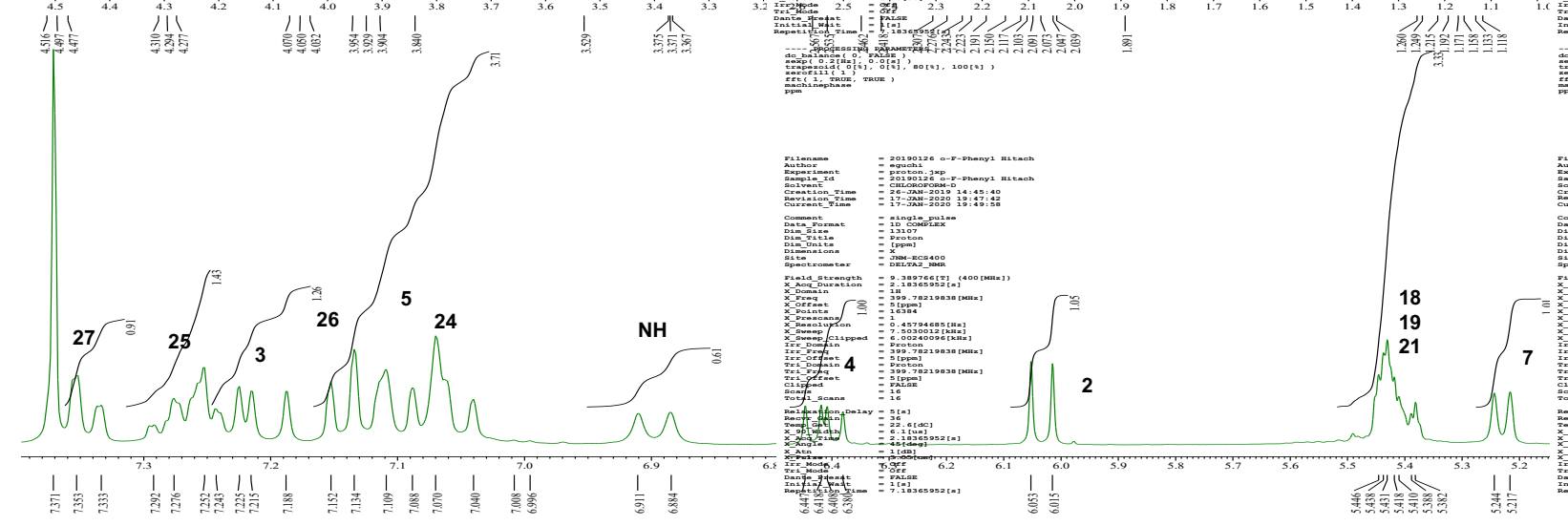


Figure S2-2. ${ }^{1} \mathrm{H}-{ }^{1} \mathrm{H}$ COSY of $o$-F-phenyl hitachimycin $(\mathbf{H}-2)\left(400 \mathrm{MHz}\right.$, in $\left.\mathrm{CDCl}_{3}+\mathrm{CD}_{3} \mathrm{OD}\right)$.
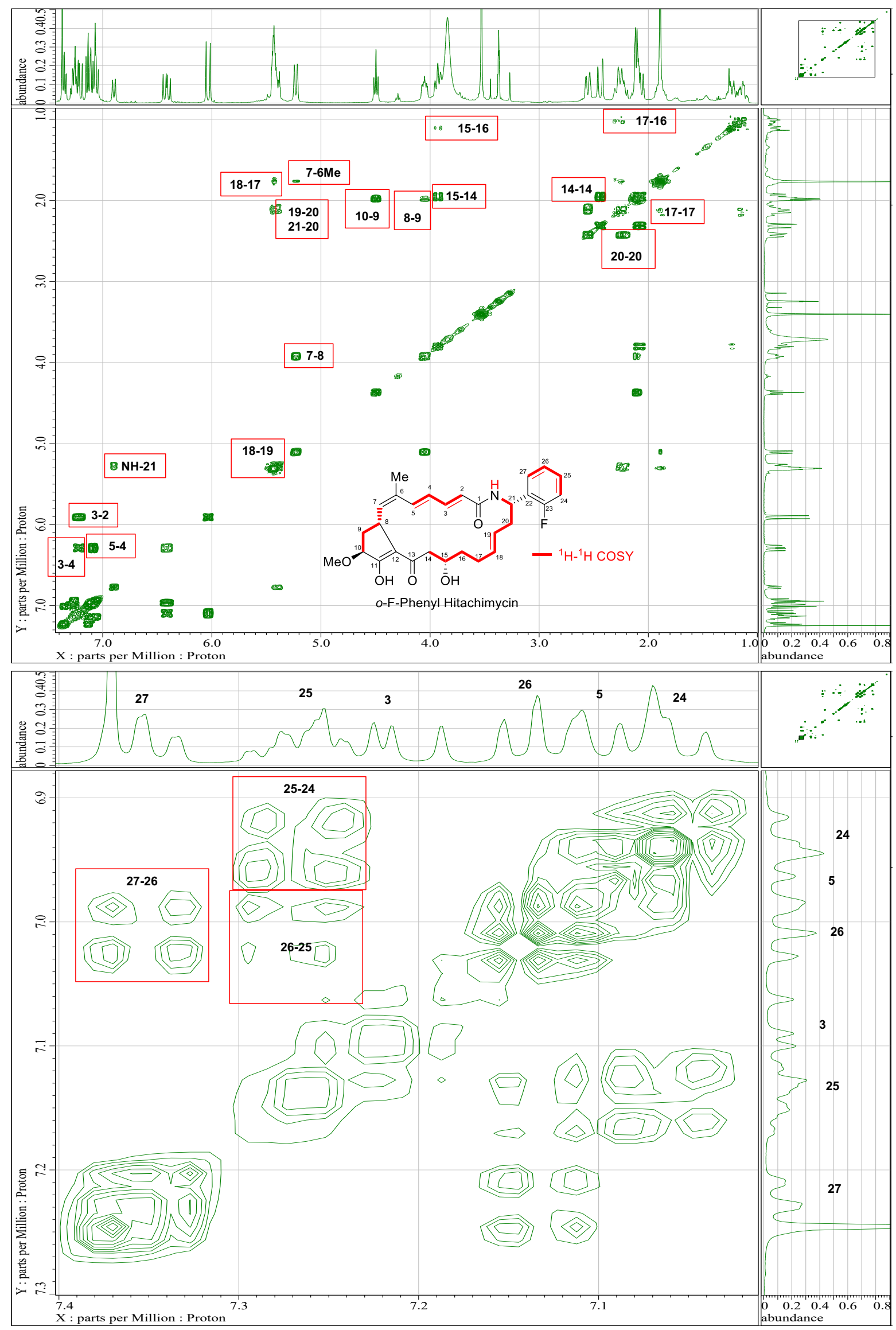
Figure S2-3. ${ }^{13} \mathrm{C}$ NMR spectra of $o$-F-phenyl hitachimycin $(\mathbf{H}-2)\left(125 \mathrm{MHz}\right.$, in $\left.\mathrm{CDCl}_{3}+\mathrm{CD}_{3} \mathrm{OD}\right)$.
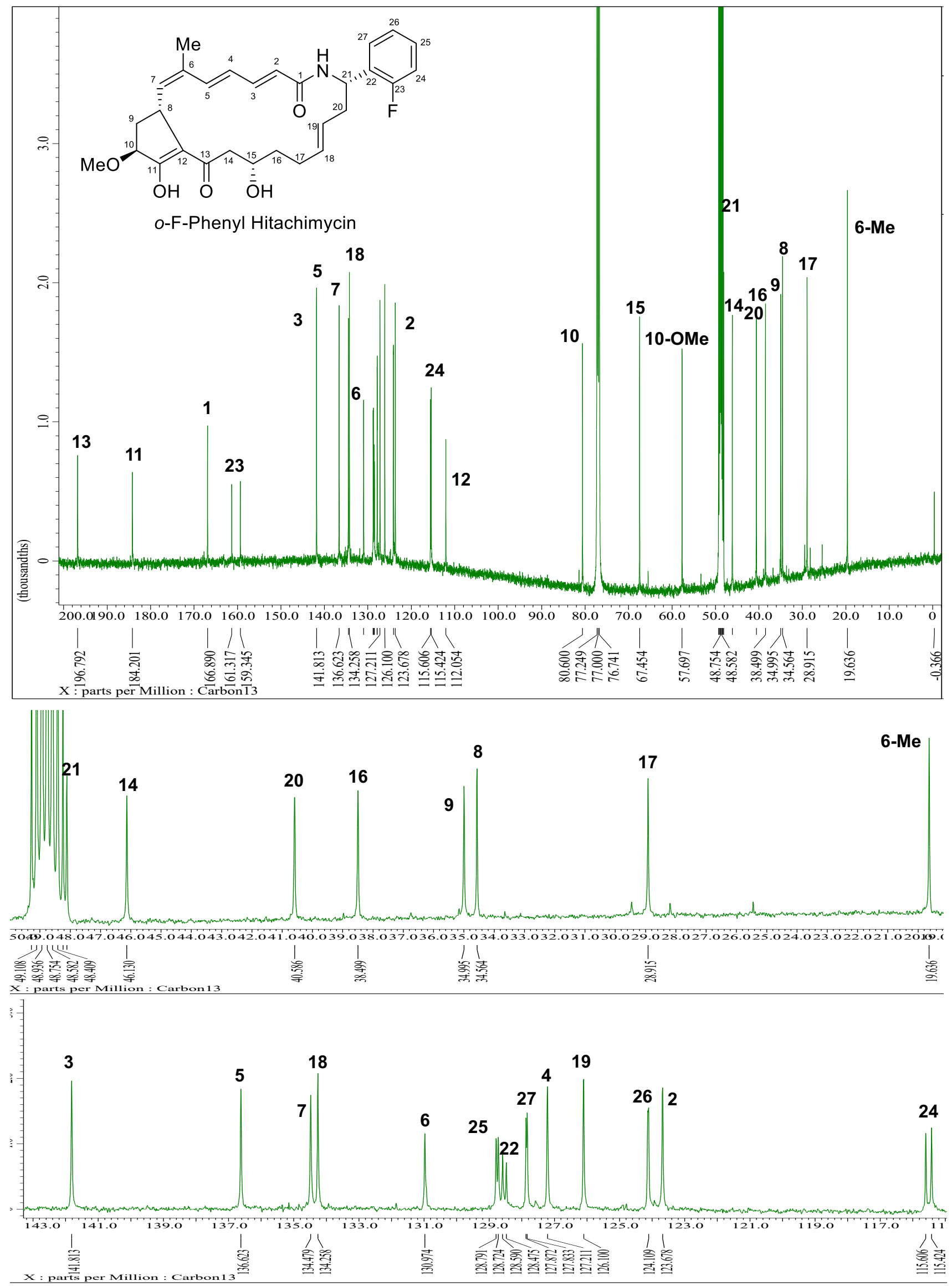
Figure S2-4. HMQC of $o$-F-phenyl hitachimycin (H-2) (in $\left.\mathrm{CDCl}_{3}+\mathrm{CD}_{3} \mathrm{OD}\right)$.
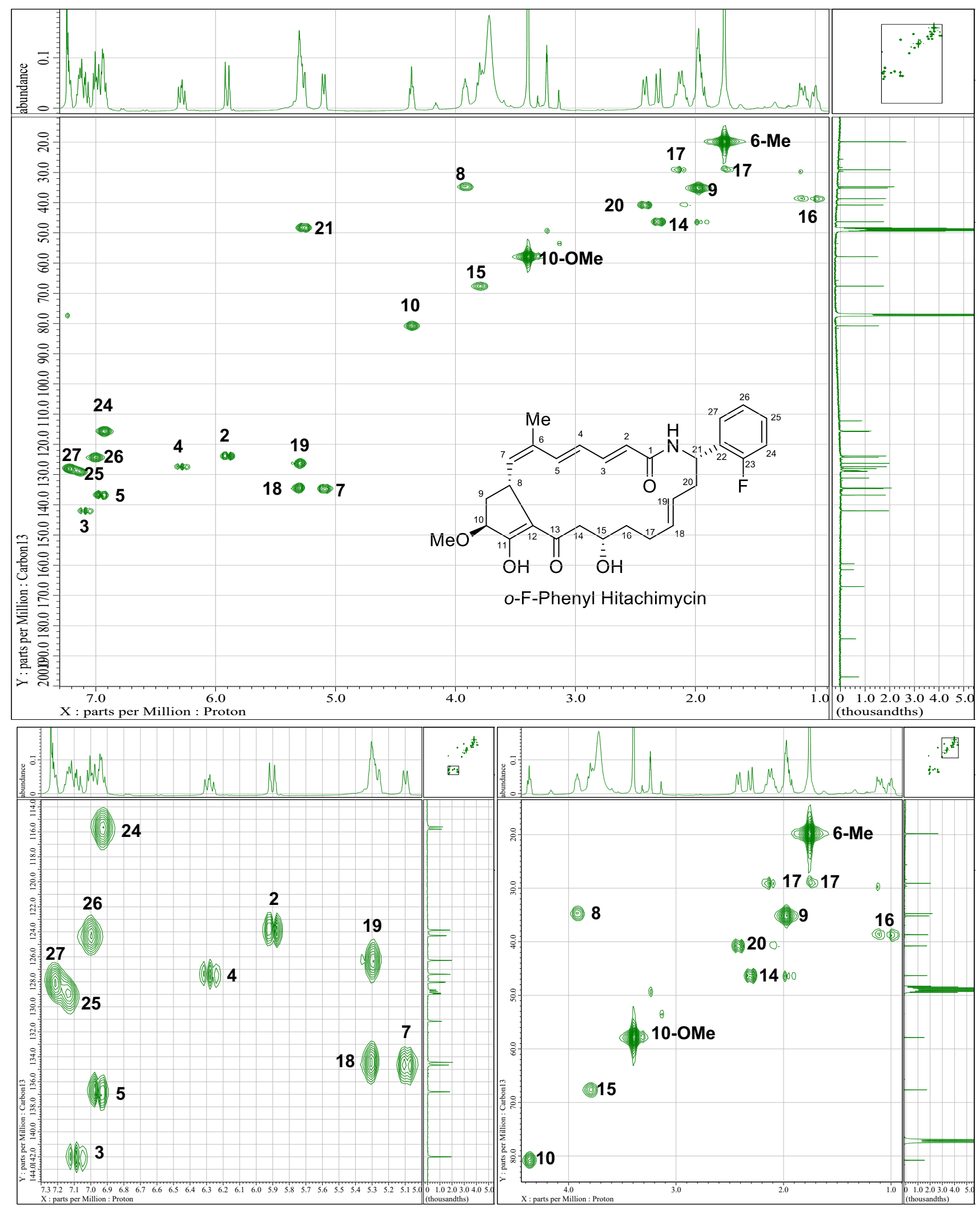
Figure S2-5. HMBC of $o$-F-phenyl hitachimycin (H-2) (in $\left.\mathrm{CDCl}_{3}+\mathrm{CD}_{3} \mathrm{OD}\right)$.

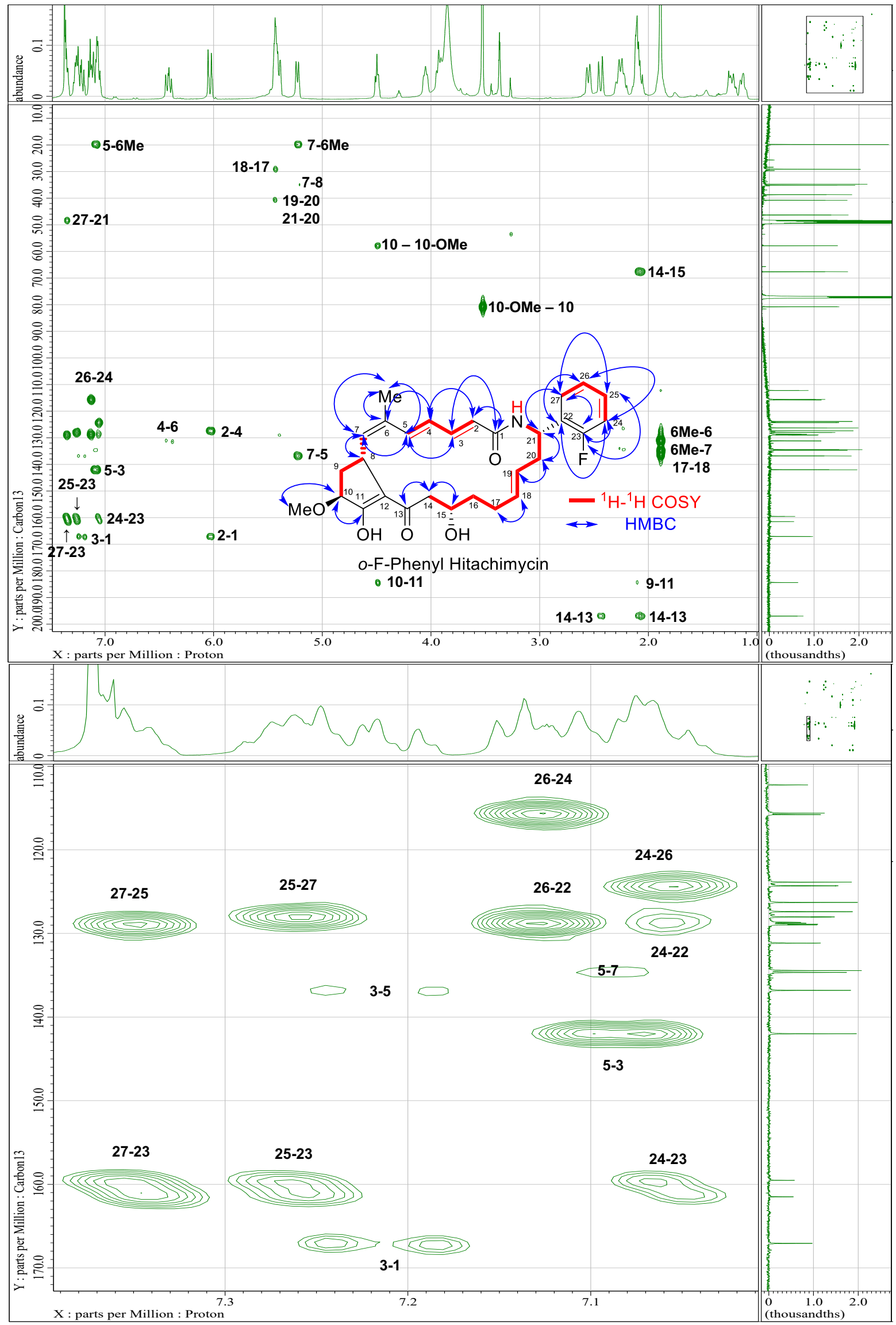


Figure S3-1. ${ }^{1} \mathrm{H}$ NMR spectra of $m$-F-phenyl hitachimycin $(\mathbf{H - 3})\left(400 \mathrm{MHz}\right.$, in $\left.\mathrm{CDCl}_{3}+\mathrm{CD}_{3} \mathrm{OD}\right)$.
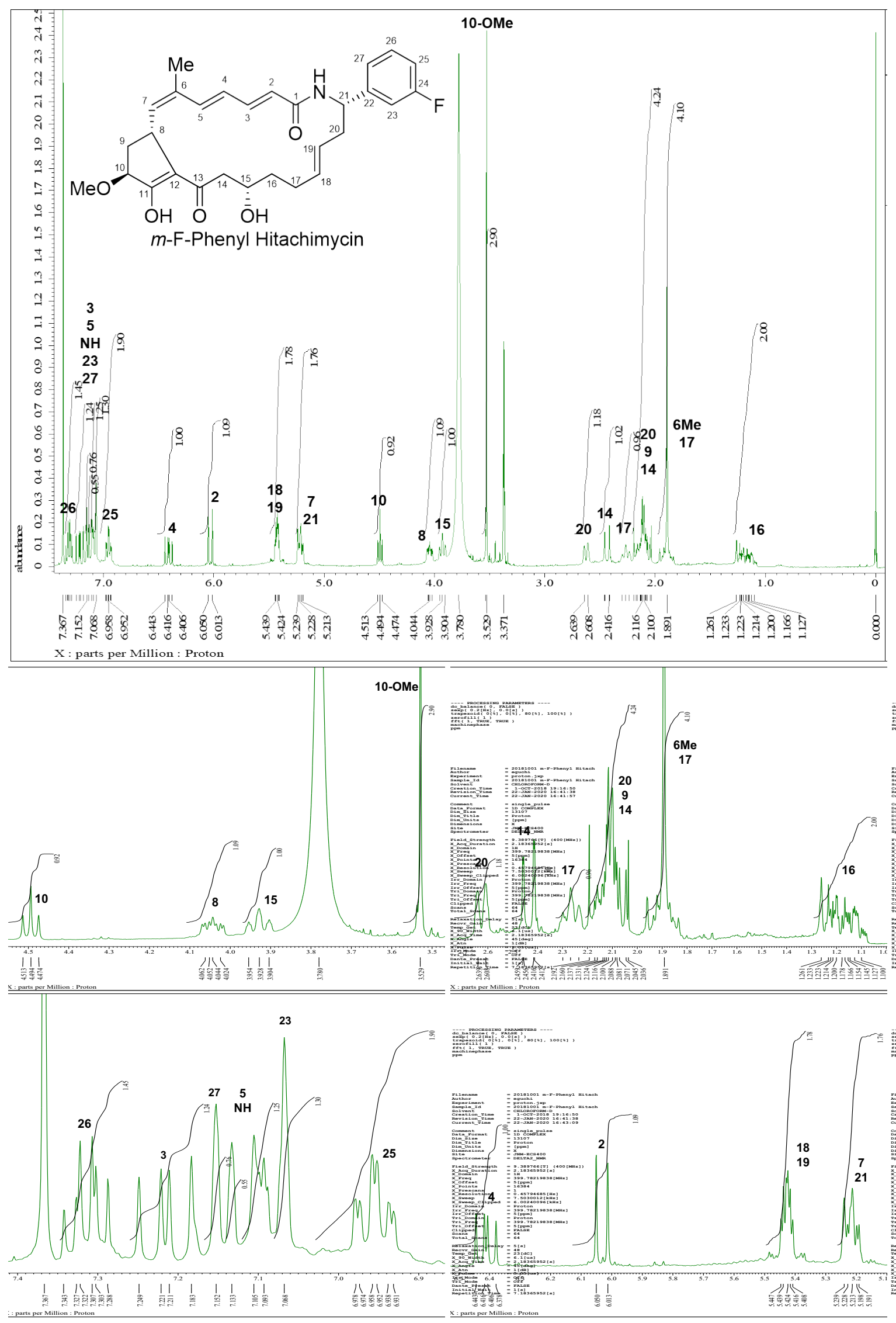
Figure S3-2. ${ }^{1} \mathrm{H}-{ }^{1} \mathrm{H}$ COSY of $m$-F-phenyl hitachimycin $(\mathbf{H}-3)$ (in $\mathrm{CDCl}_{3}+\mathrm{CD}_{3} \mathrm{OD}$ ).

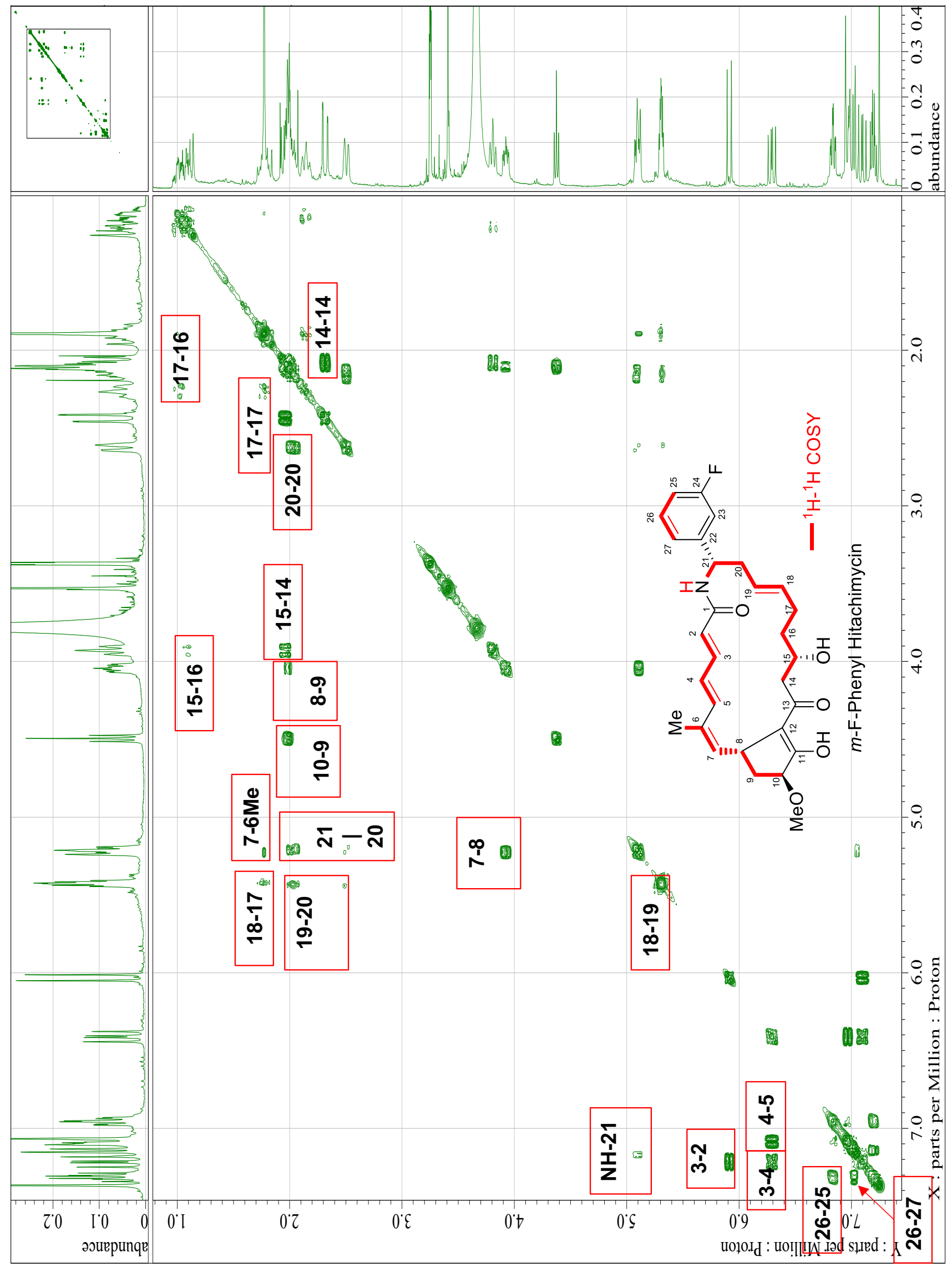


Figure S3-3. ${ }^{13} \mathrm{C}$ NMR spectra of $m$-F-phenyl hitachimycin $(\mathbf{H - 3})\left(125 \mathrm{MHz}\right.$, in $\left.\mathrm{CDCl}_{3}+\mathrm{CD}_{3} \mathrm{OD}\right)$.
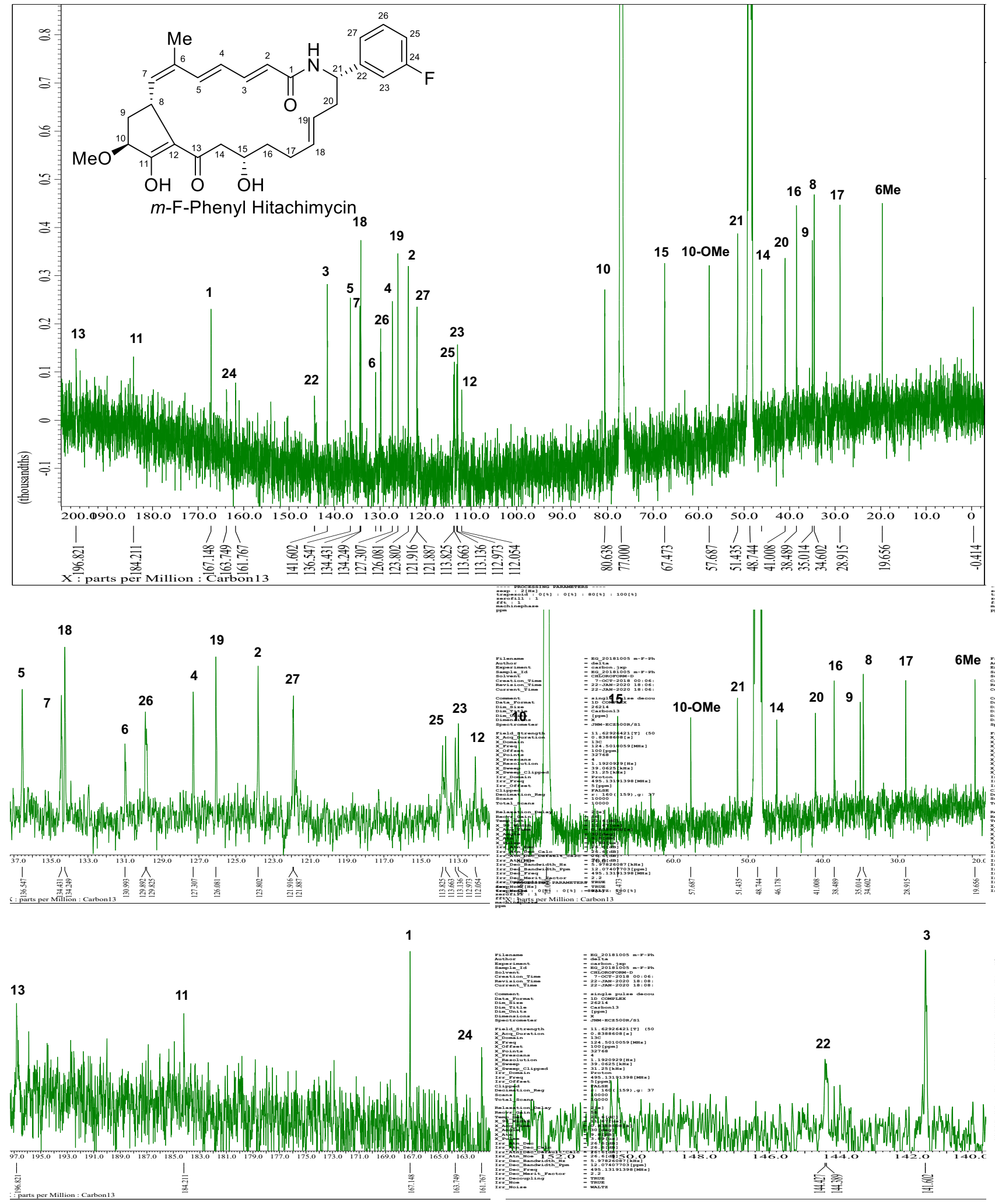
Figure S4-1. ${ }^{1} \mathrm{H}$ NMR spectra of $p$-F-phenyl hitachimycin $(\mathbf{H}-4)\left(400 \mathrm{MHz}\right.$, in $\left.\mathrm{CDCl}_{3}+\mathrm{CD}_{3} \mathrm{OD}\right)$.
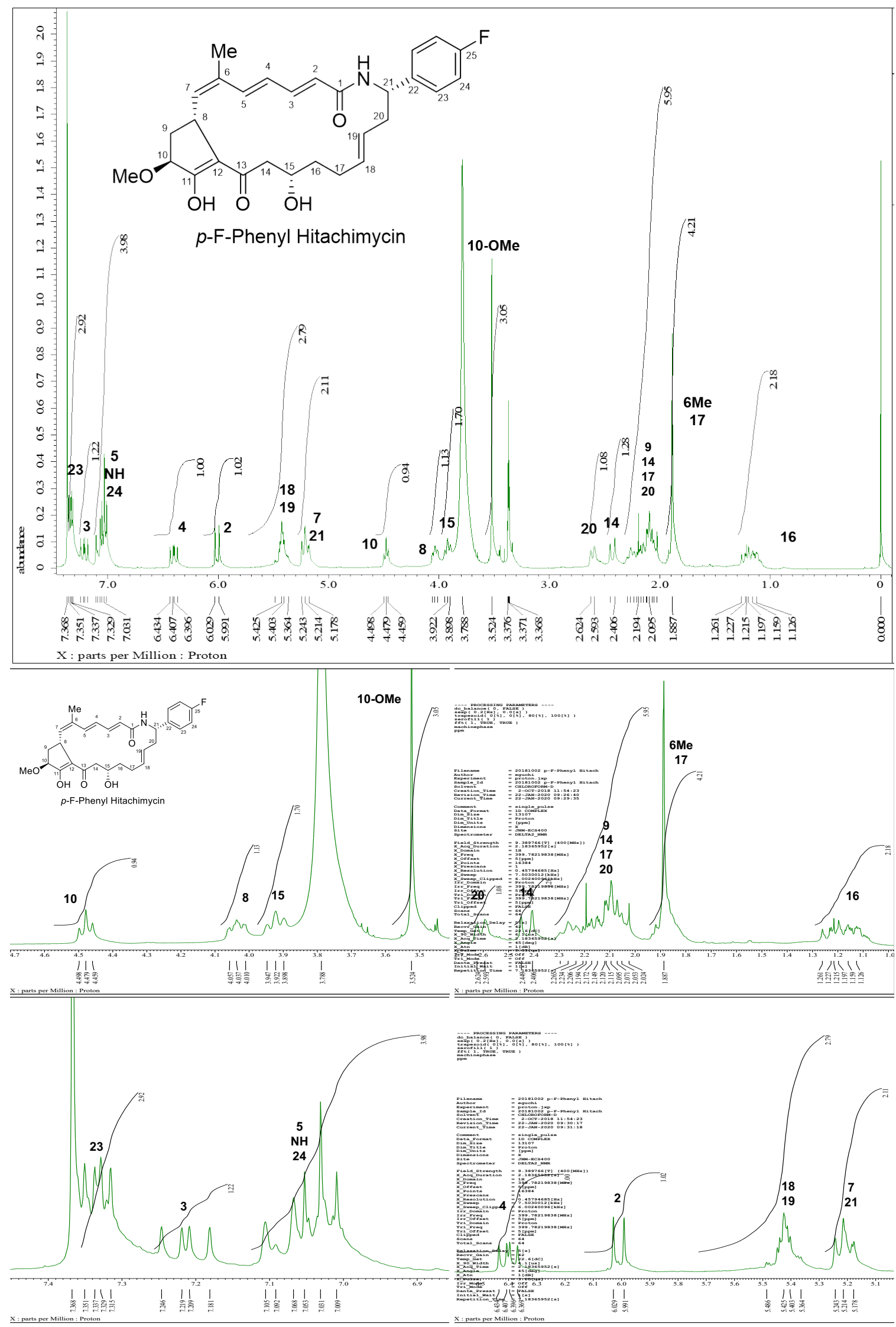
Figure S4-2. ${ }^{1} \mathrm{H}-{ }^{1} \mathrm{H}$ COSY of $p$-F-phenyl hitachimycin $(\mathbf{H}-4)\left(\right.$ in $\left.\mathrm{CDCl}_{3}+\mathrm{CD}_{3} \mathrm{OD}\right)$.

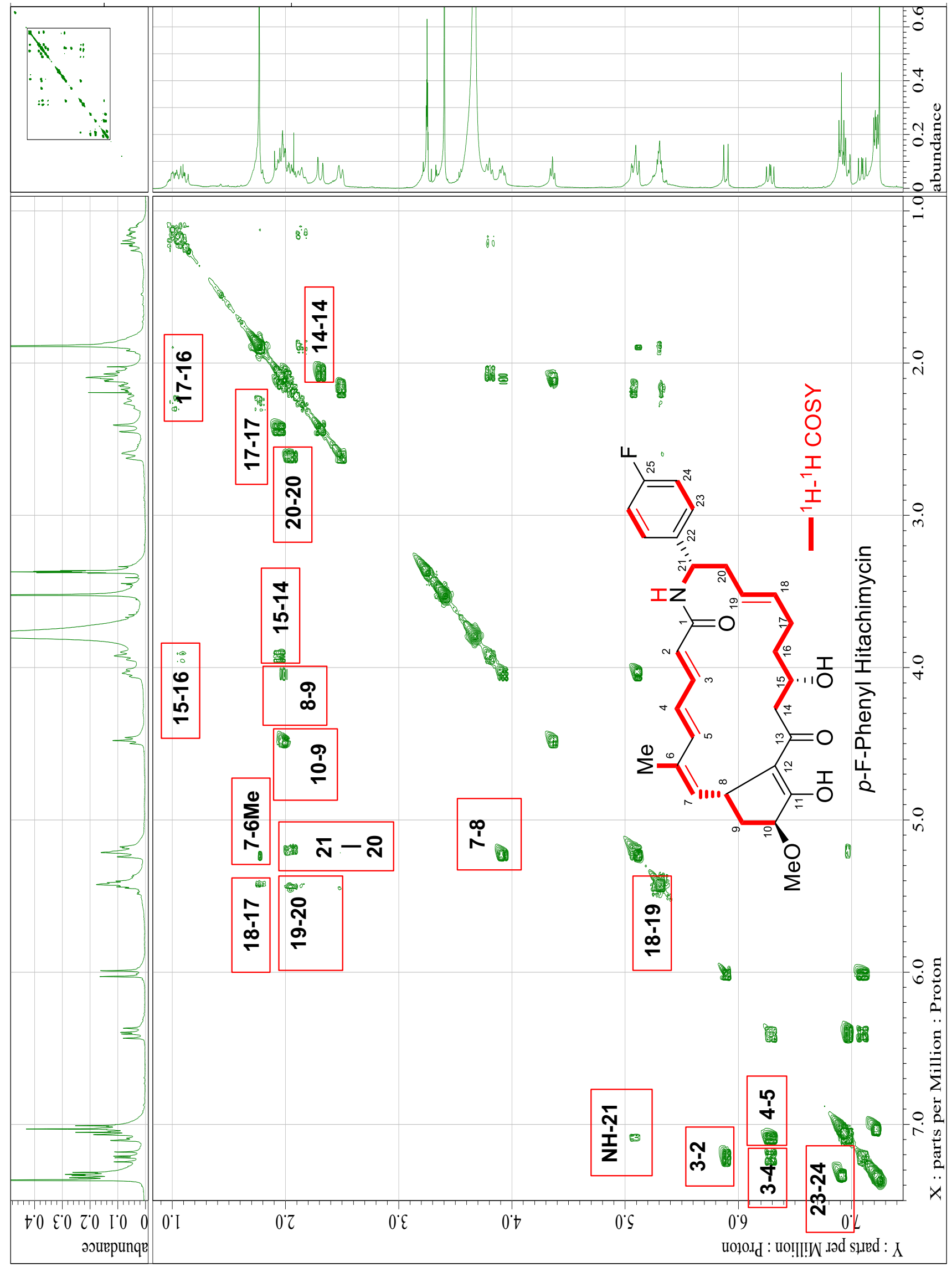


Figure S4-3. ${ }^{13} \mathrm{C}$ NMR spectra of $p$-F-phenyl hitachimycin $(\mathbf{H}-4)\left(125 \mathrm{MHz}\right.$, in $\left.\mathrm{CDCl}_{3}+\mathrm{CD}_{3} \mathrm{OD}\right)$.
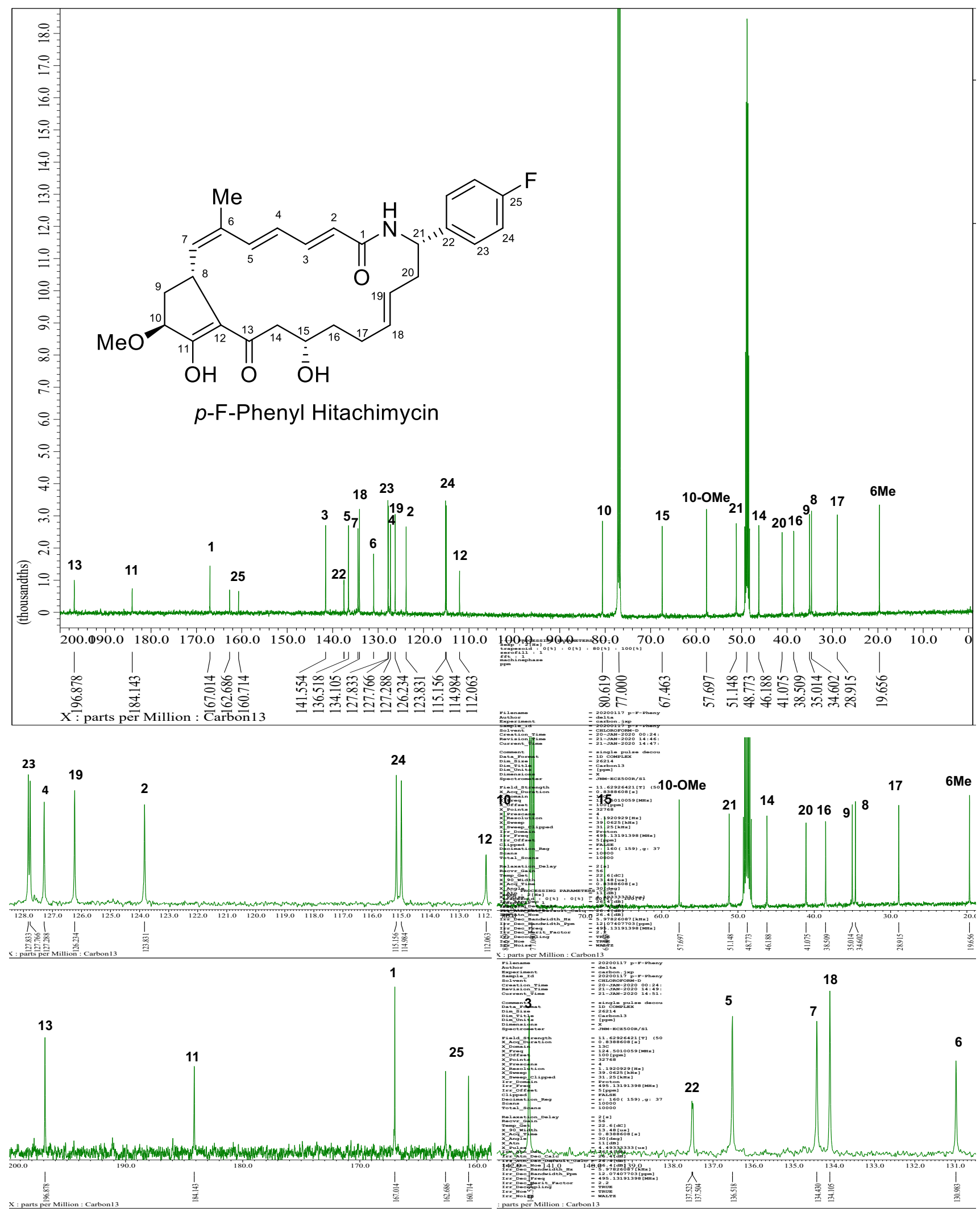
Figure S4-4. HMQC of $p$-F-phenyl hitachimycin (H-4) (in $\left.\mathrm{CDCl}_{3}+\mathrm{CD}_{3} \mathrm{OD}\right)$.

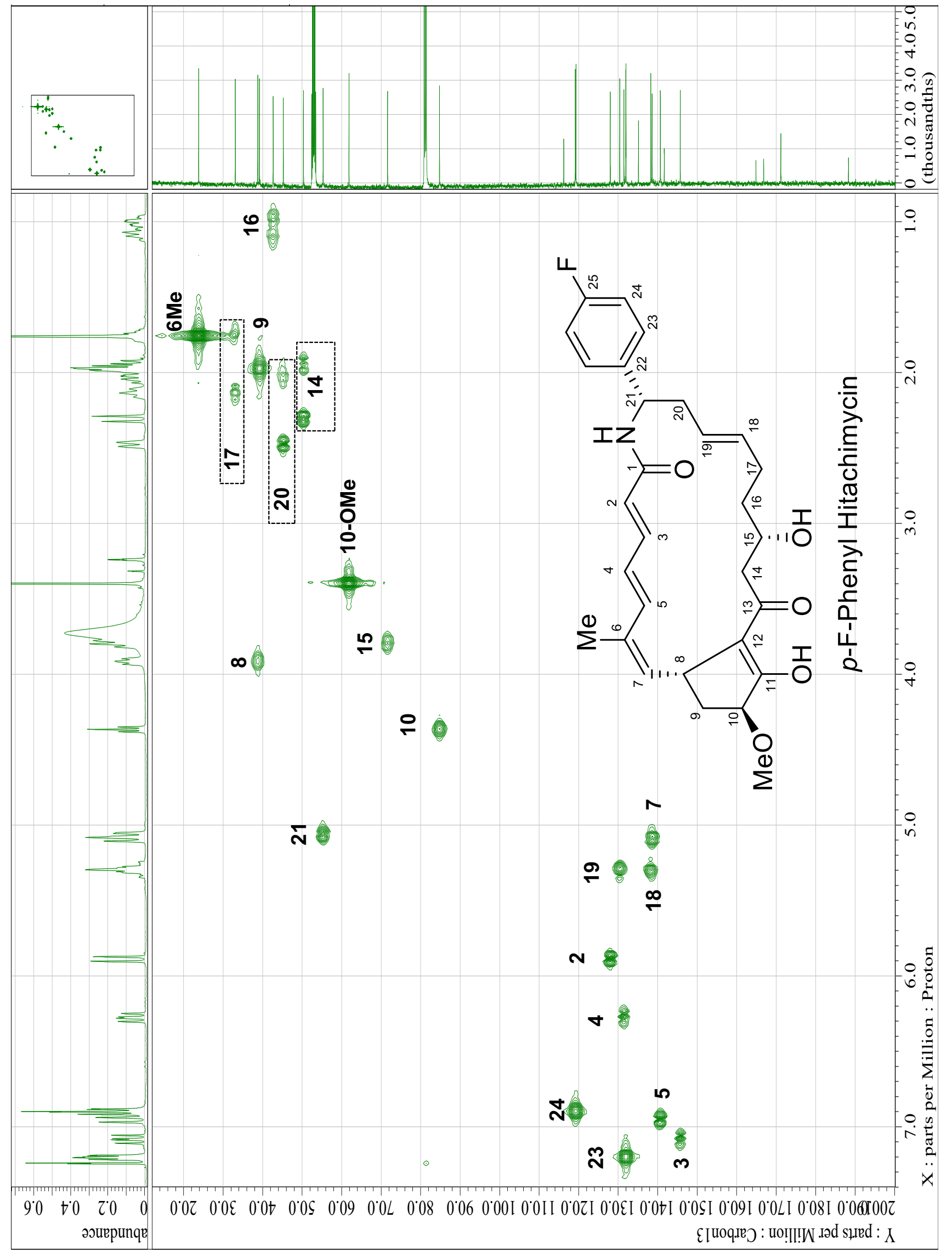


Figure S4-5. HMBC of $p$-F-phenyl hitachimycin (H-4) (in $\left.\mathrm{CDCl}_{3}+\mathrm{CD}_{3} \mathrm{OD}\right)$.

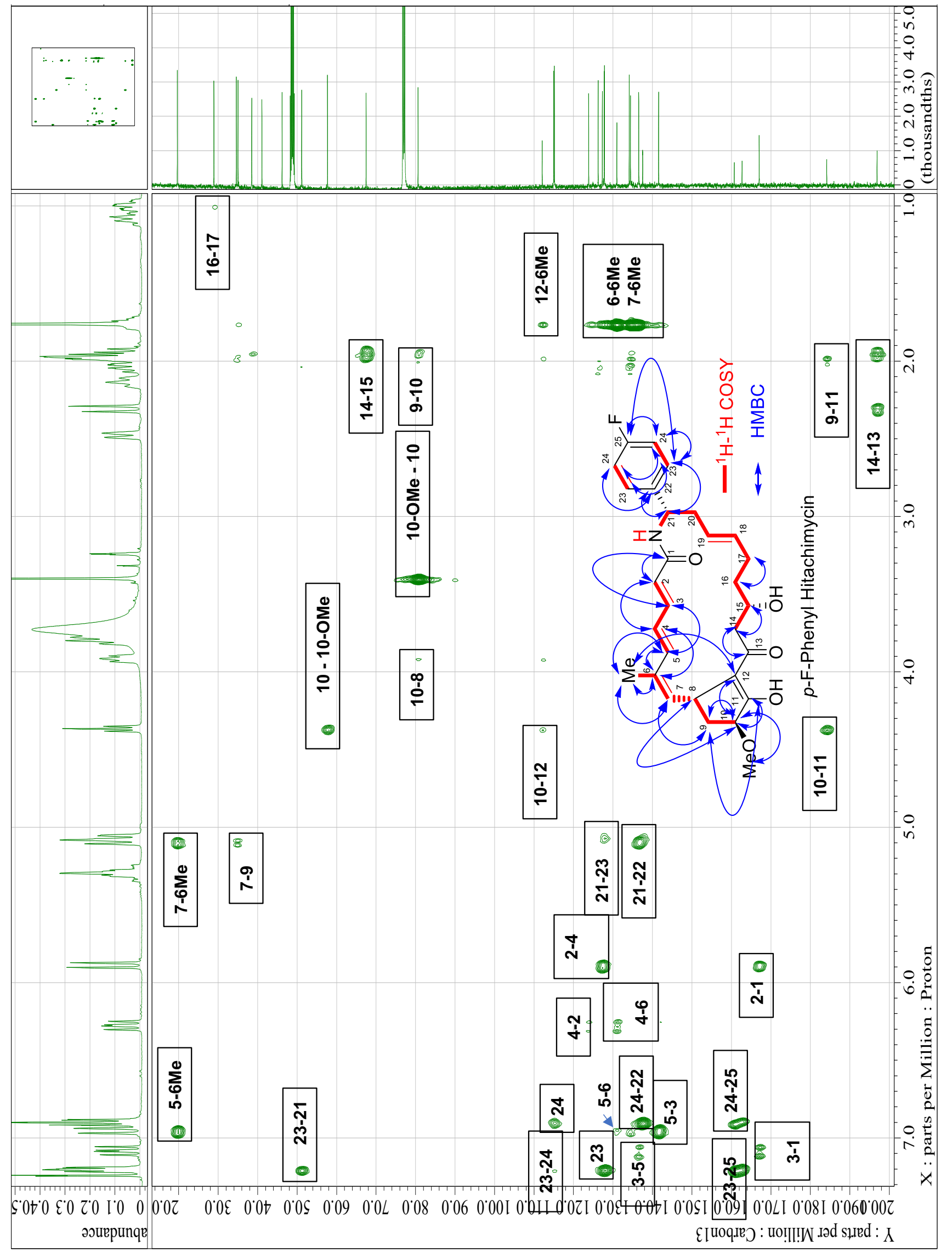


Figure S5-1. ${ }^{1} \mathrm{H}$ NMR spectra of $m$-Cl-phenyl hitachimycin $(\mathbf{H}-5)\left(400 \mathrm{MHz}\right.$, in $\left.\mathrm{CDCl}_{3}+\mathrm{CD}_{3} \mathrm{OD}\right)$.
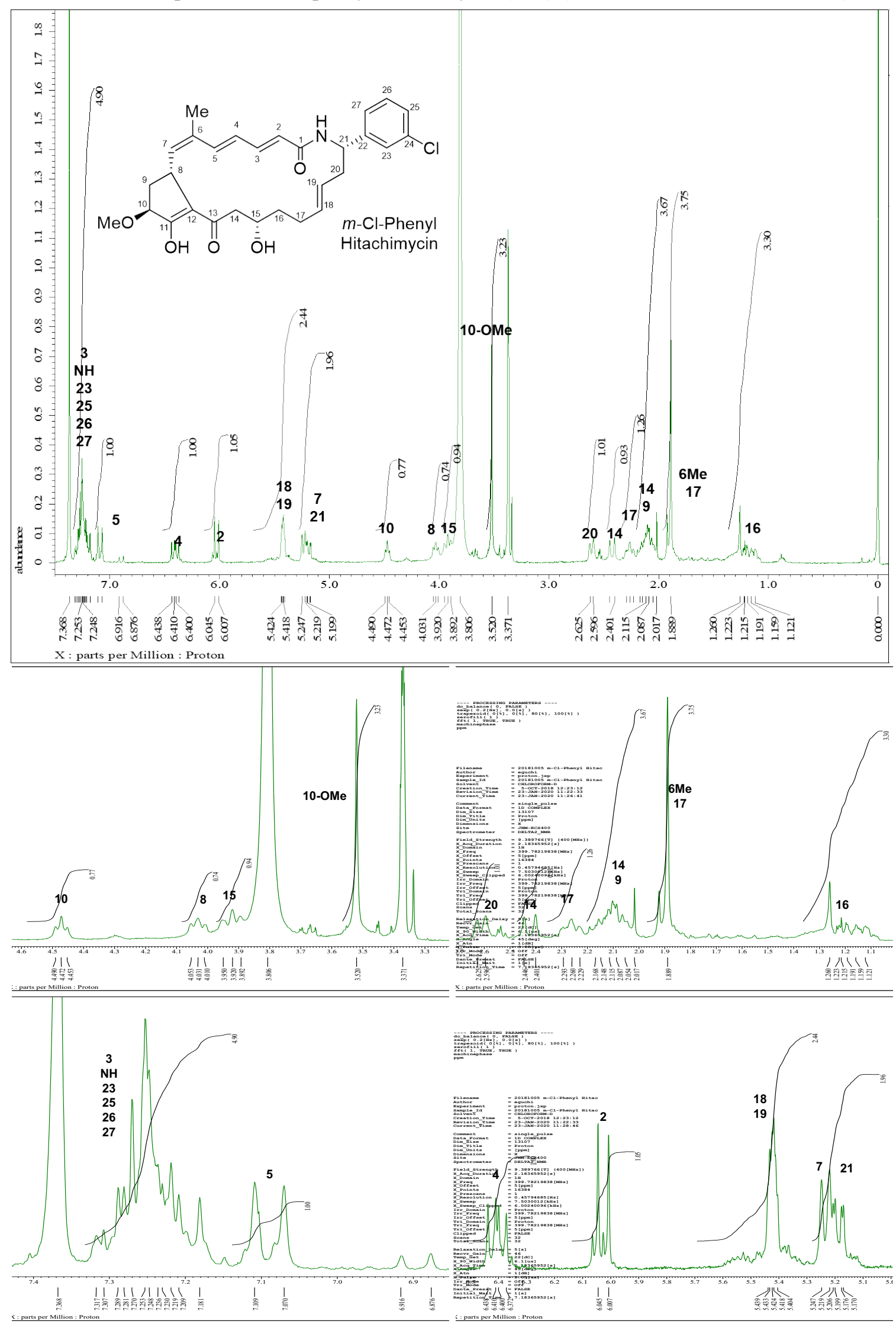
Figure S5-2. ${ }^{1} \mathrm{H}-{ }^{1} \mathrm{H}$ COSY of $m$-Cl-phenyl hitachimycin (H-5) (in $\mathrm{CDCl}_{3}+\mathrm{CD}_{3} \mathrm{OD}$ ).

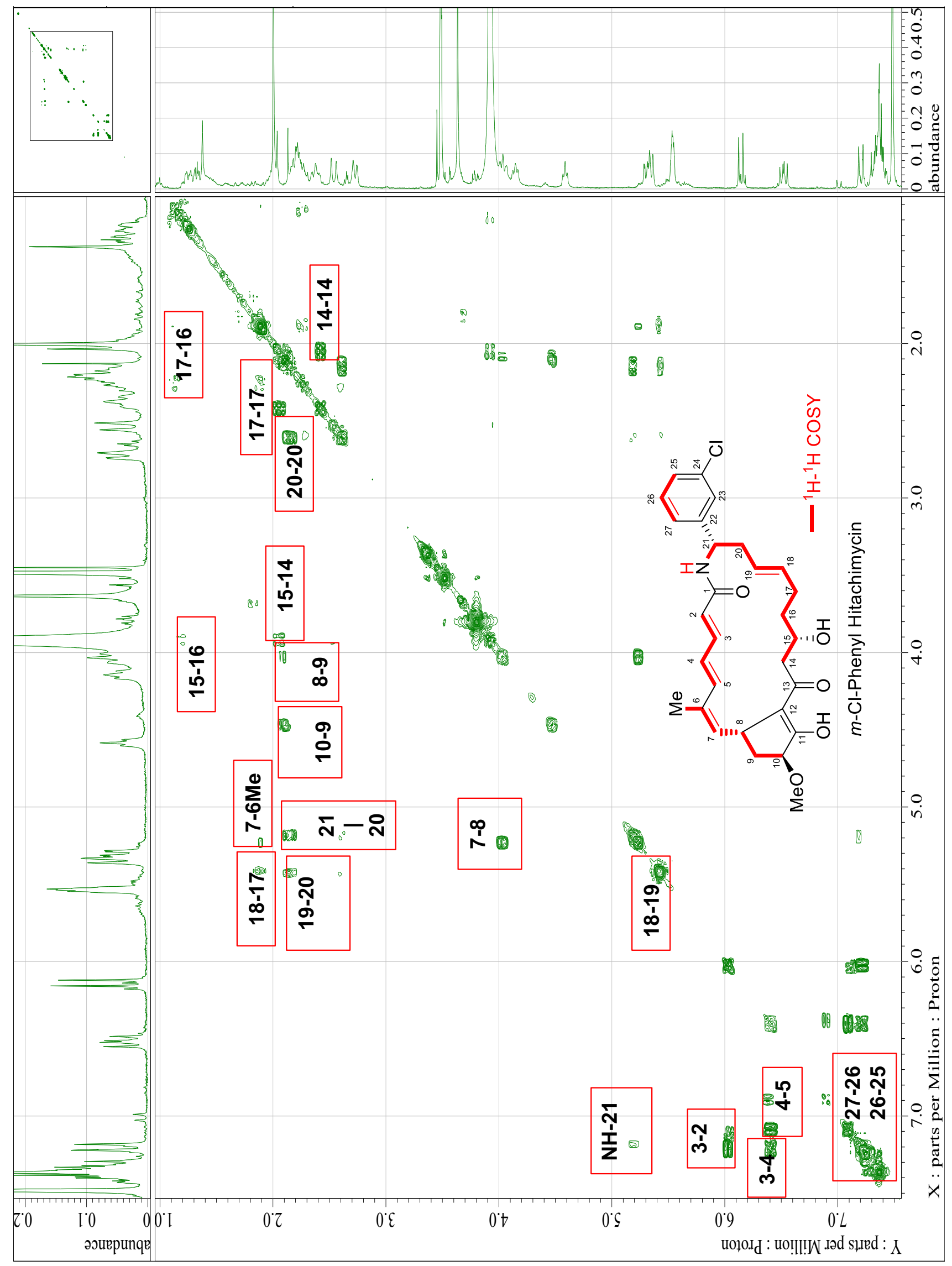


Figure S5-3. ${ }^{13} \mathrm{C}$ NMR spectra of $m$-Cl-phenyl hitachimycin $(\mathbf{H}-5)\left(125 \mathrm{MHz}\right.$, in $\left.\mathrm{CDCl}_{3}+\mathrm{CD}_{3} \mathrm{OD}\right)$.

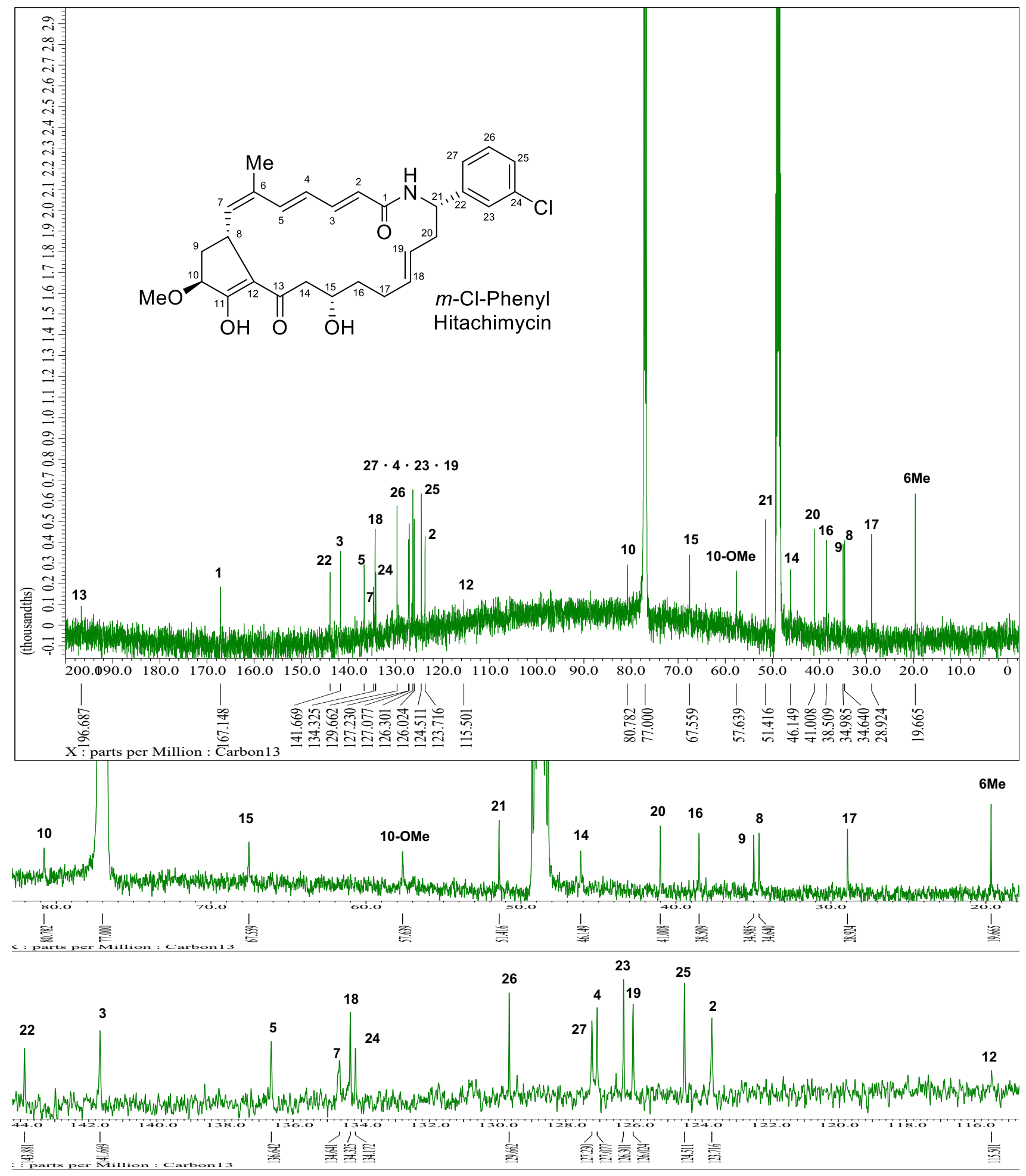


Figure S5-4. HMQC of $m$-Cl-phenyl hitachimycin (H-5) (in $\left.\mathrm{CDCl}_{3}+\mathrm{CD}_{3} \mathrm{OD}\right)$.

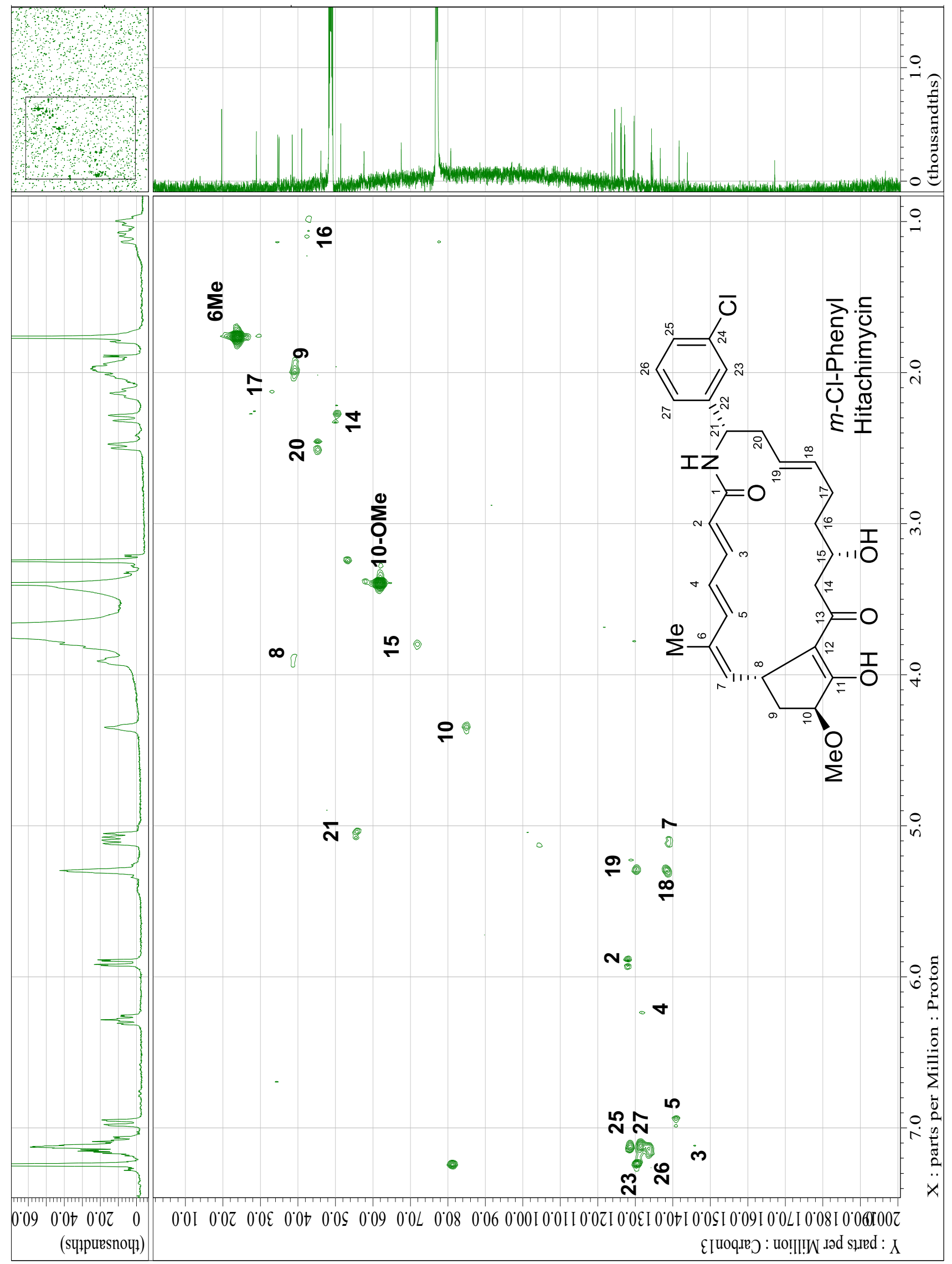


Figure S6-1. ${ }^{1} \mathrm{H}$ NMR spectra of $m$-Br-phenyl hitachimycin (H-6) $\left(400 \mathrm{MHz}\right.$, in $\left.\mathrm{CDCl}_{3}+\mathrm{CD}_{3} \mathrm{OD}\right)$.

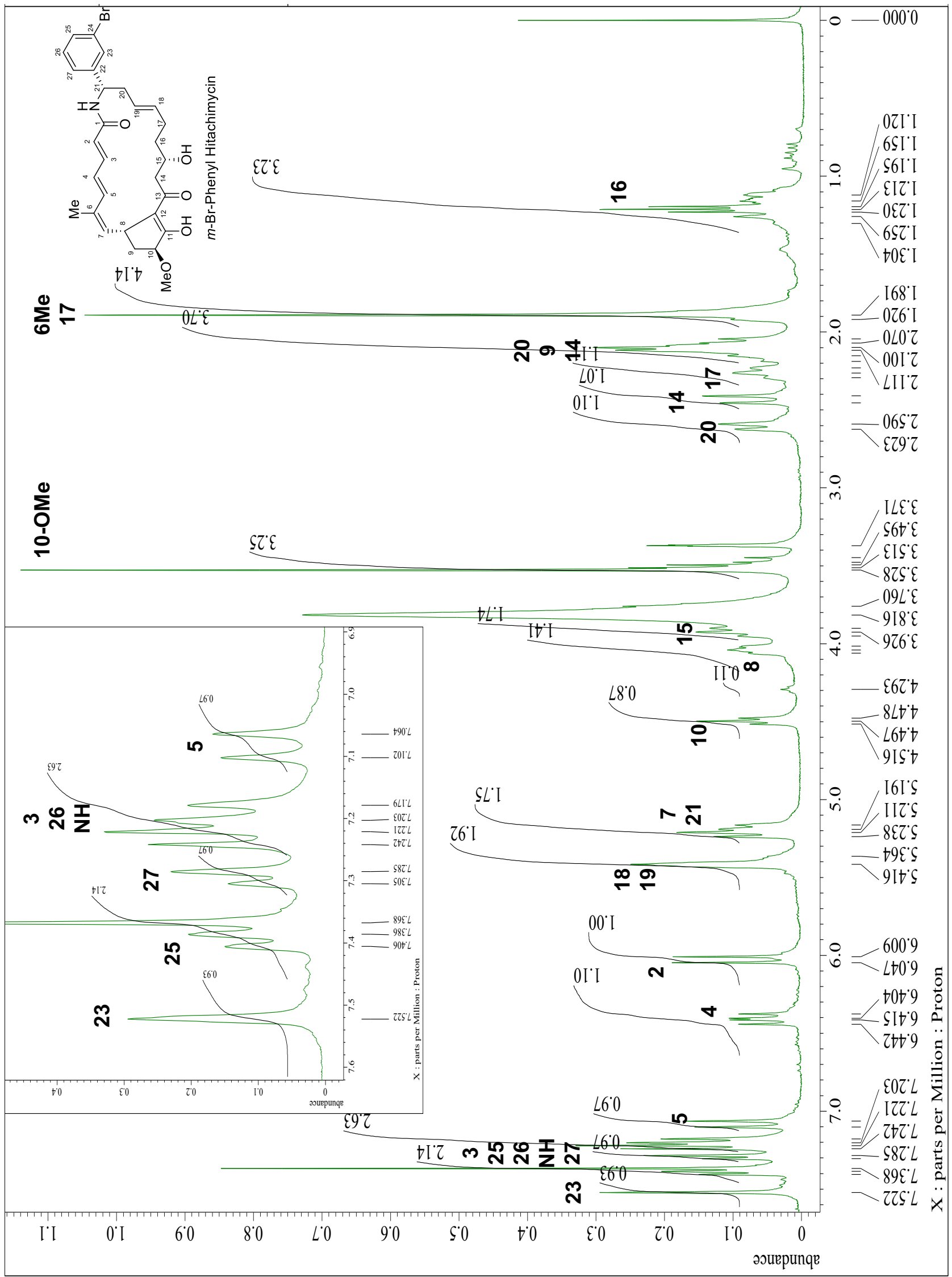


Figure S6-2. ${ }^{1} \mathrm{H}-{ }^{1} \mathrm{H}$ COSY of $m$-Br-phenyl hitachimycin (H-6) (in $\mathrm{CDCl}_{3}+\mathrm{CD}_{3} \mathrm{OD}$ ).

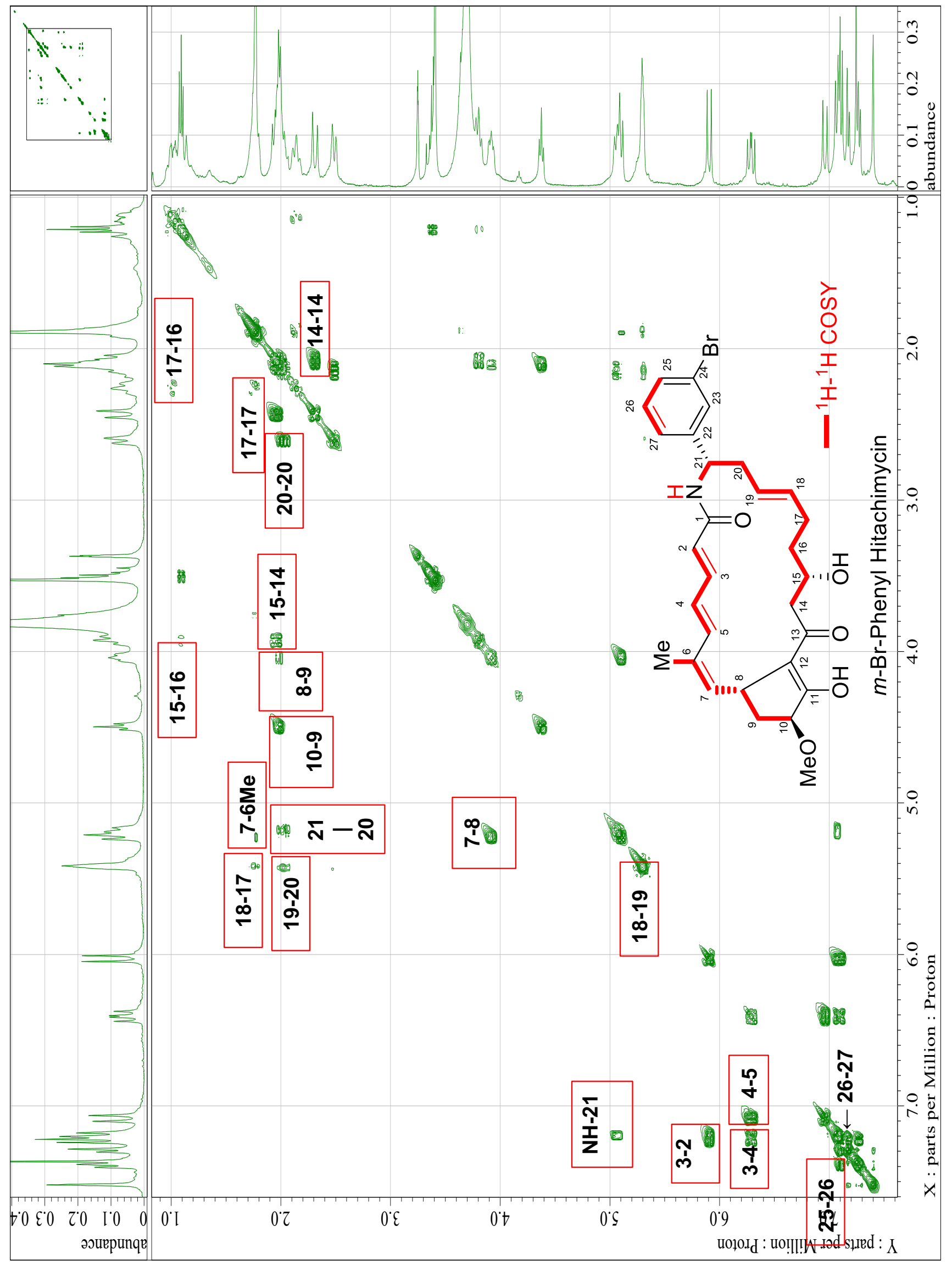


Figure S6-3. ${ }^{13} \mathrm{C}$ NMR spectra of $m$-Br-phenyl hitachimycin (H-6) (125 MHz, in $\left.\mathrm{CDCl}_{3}+\mathrm{CD}_{3} \mathrm{OD}\right)$.

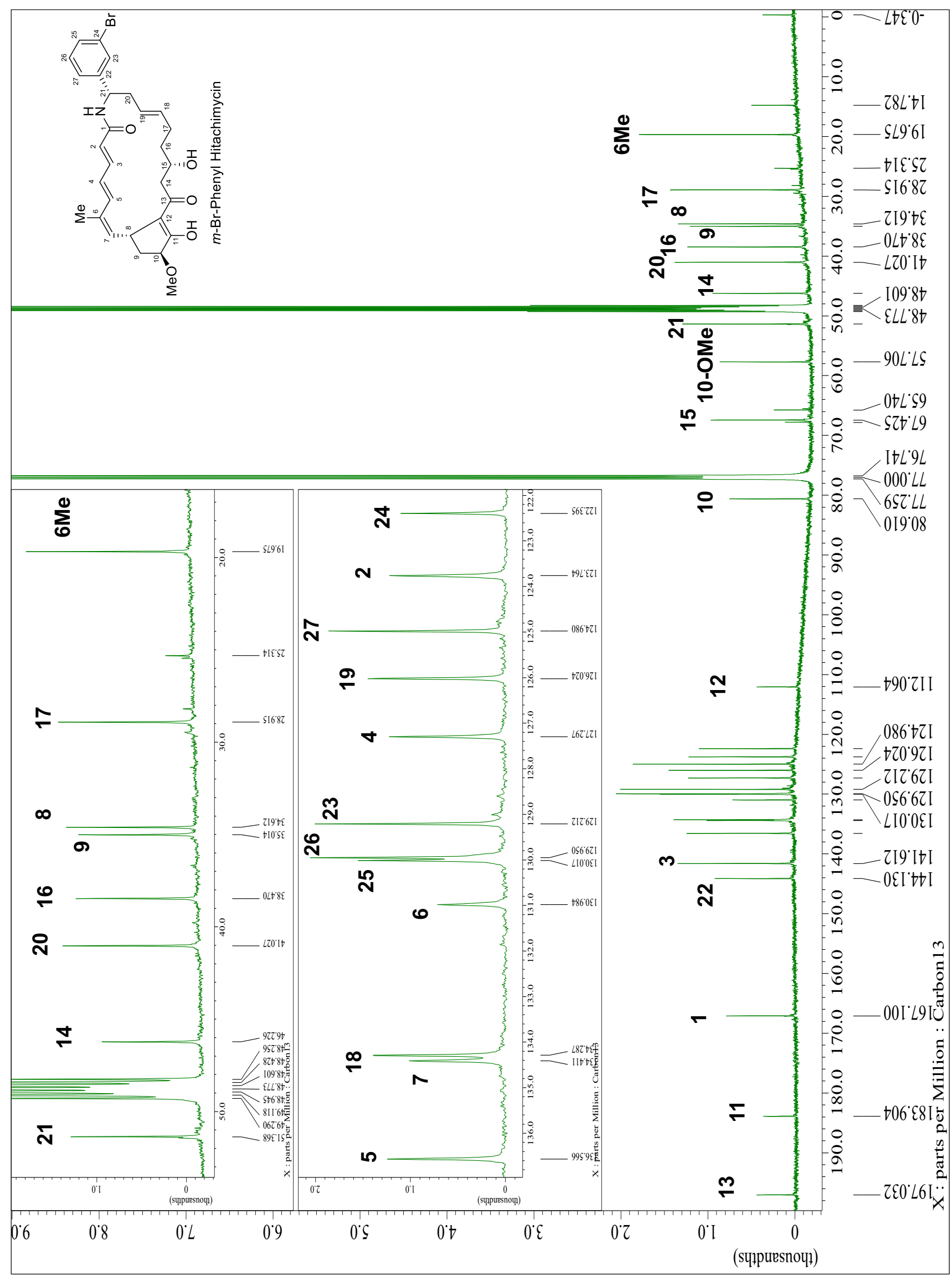


Figure S6-4. HMQC of $m$-Br-phenyl hitachimycin (H-6) (in $\left.\mathrm{CDCl}_{3}+\mathrm{CD}_{3} \mathrm{OD}\right)$.

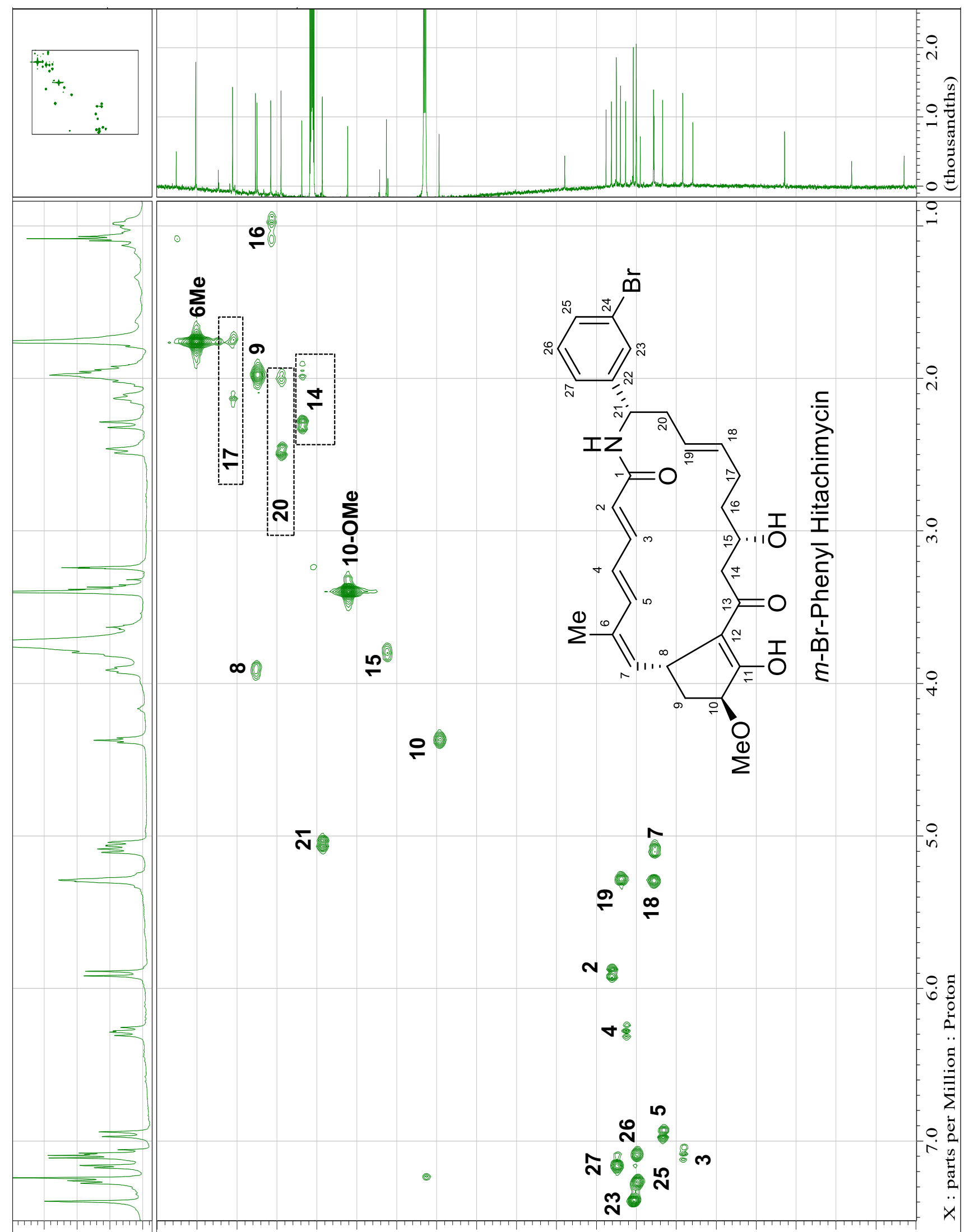

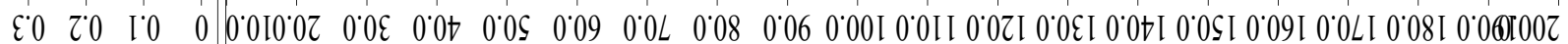
әงuepunqe

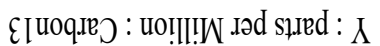


Figure S7-1. ${ }^{1} \mathrm{H}$ NMR spectra of $m$-Me-phenyl hitachimycin $(\mathbf{H}-7)\left(400 \mathrm{MHz}\right.$, in $\left.\mathrm{CDCl}_{3}+\mathrm{CD}_{3} \mathrm{OD}\right)$.

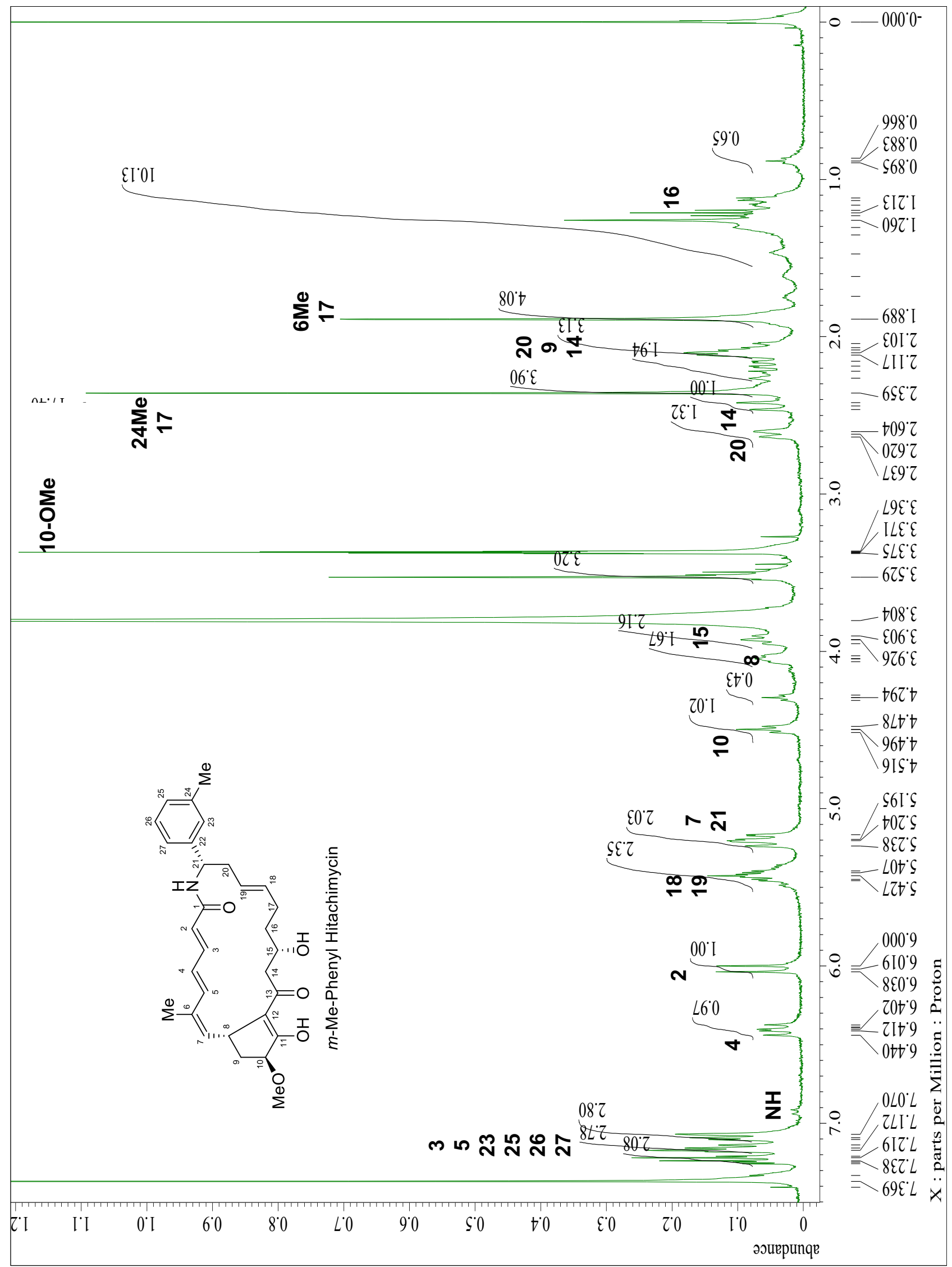


Figure S7-2. ${ }^{1} \mathrm{H}-{ }^{1} \mathrm{H}$ COSY of $m$-Me-phenyl hitachimycin (H-7) (in $\mathrm{CDCl}_{3}+\mathrm{CD}_{3} \mathrm{OD}$ ).

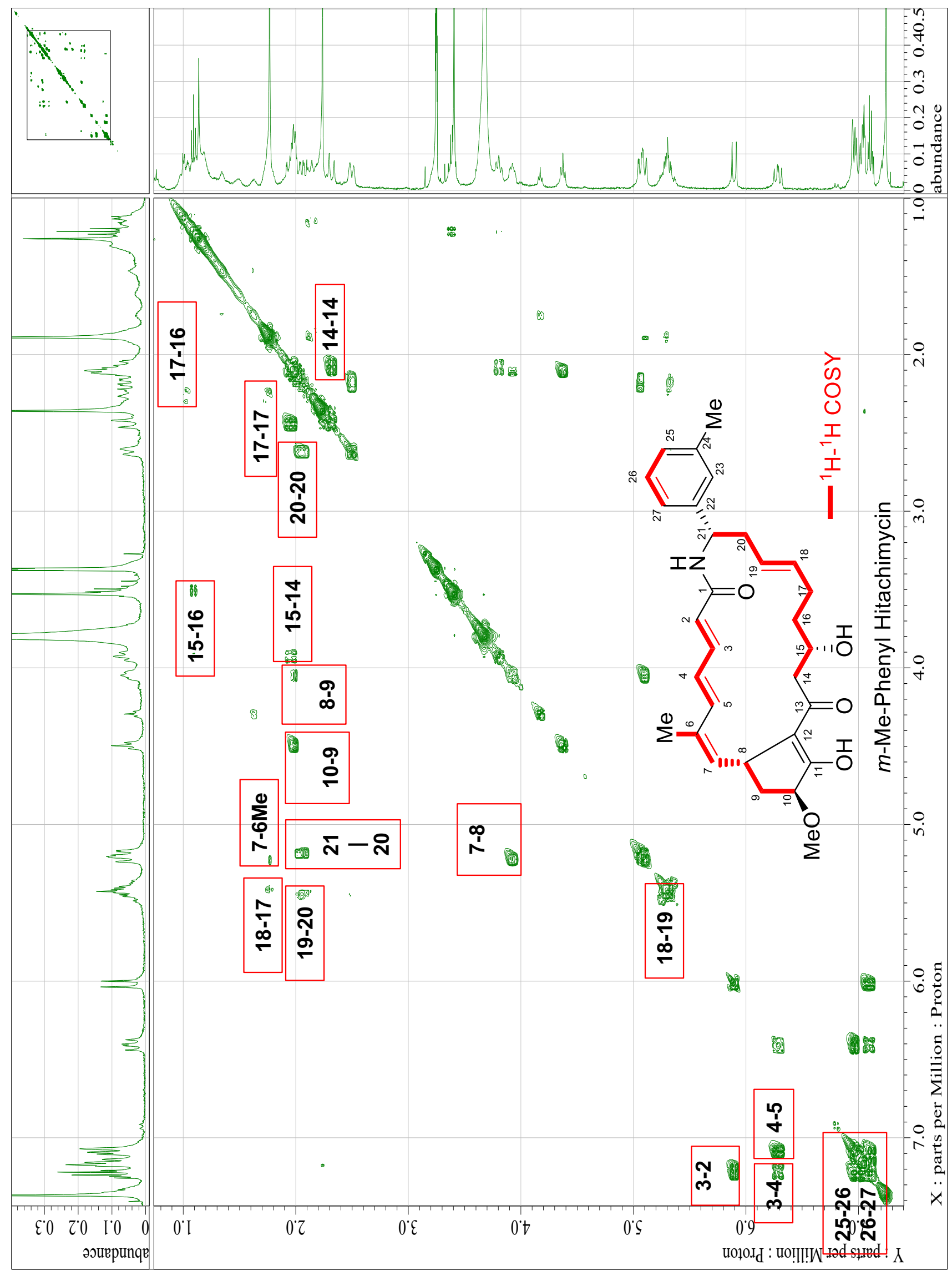


Figure S7-3. ${ }^{13} \mathrm{C}$ NMR spectra of $m$-Me-phenyl hitachimycin (H-7) $\left(125 \mathrm{MHz}\right.$, in $\left.\mathrm{CDCl}_{3}+\mathrm{CD}_{3} \mathrm{OD}\right)$.

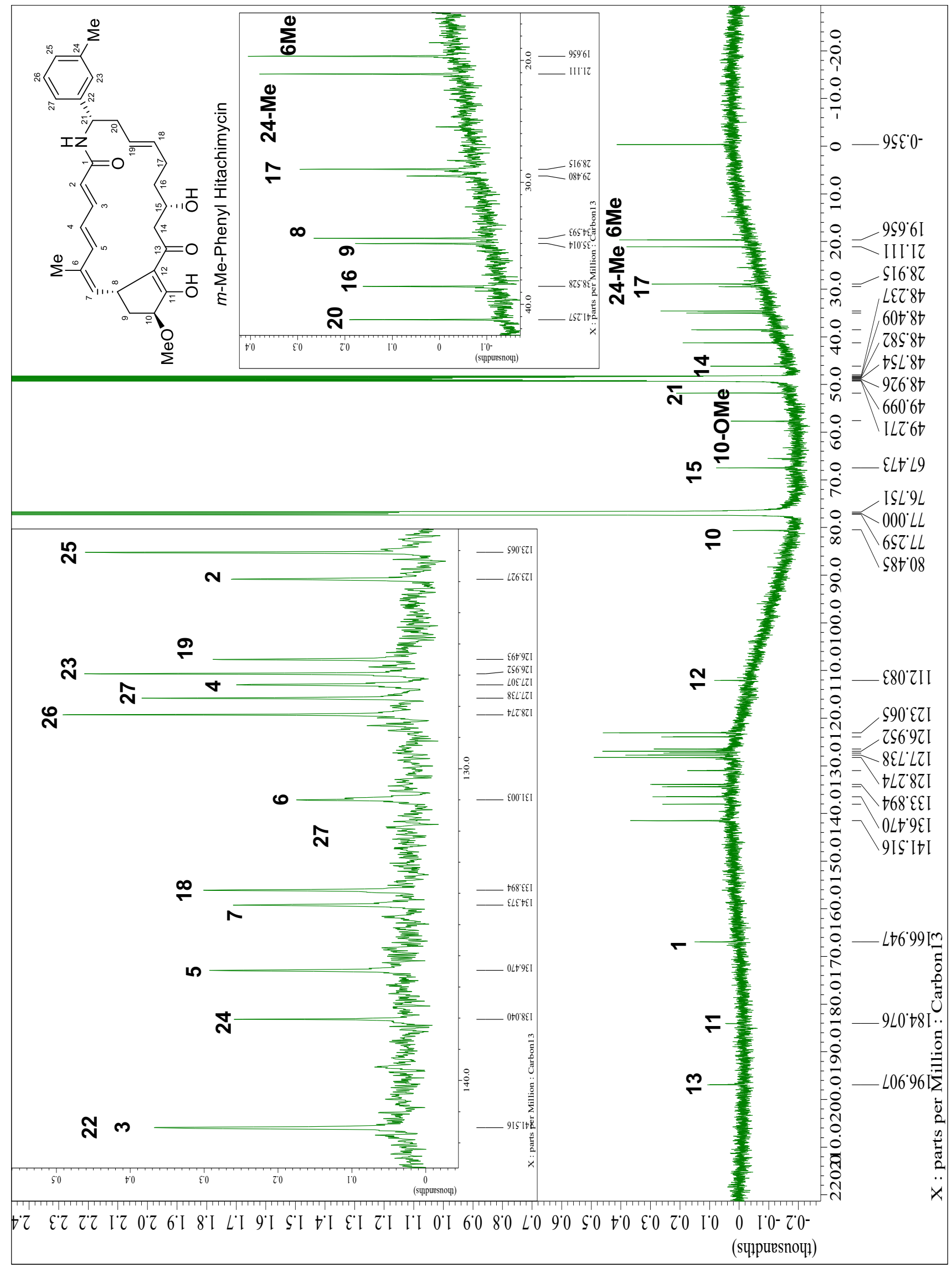


Figure S8-1. ${ }^{1} \mathrm{H}$ NMR spectra of 3-thienyl hitachimycin (H-8) $\left(400 \mathrm{MHz}\right.$, in $\left.\mathrm{CDCl}_{3}+\mathrm{CD}_{3} \mathrm{OD}\right)$.

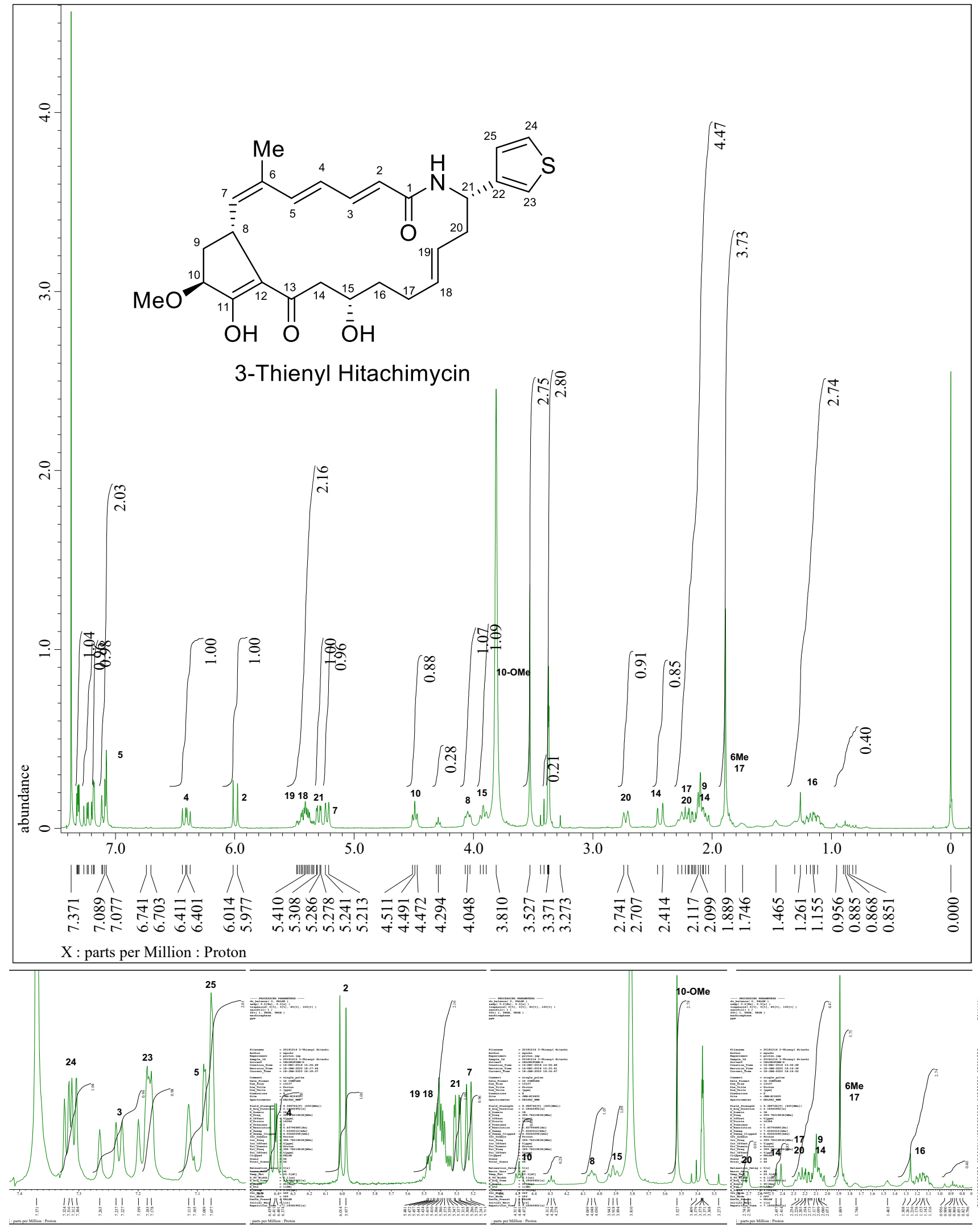


Figure S8-2. ${ }^{1} \mathrm{H}-{ }^{1} \mathrm{H}$ COSY of 3-thienyl hitachimycin (H-8) (in $\left.\mathrm{CDCl}_{3}+\mathrm{CD}_{3} \mathrm{OD}\right)$.

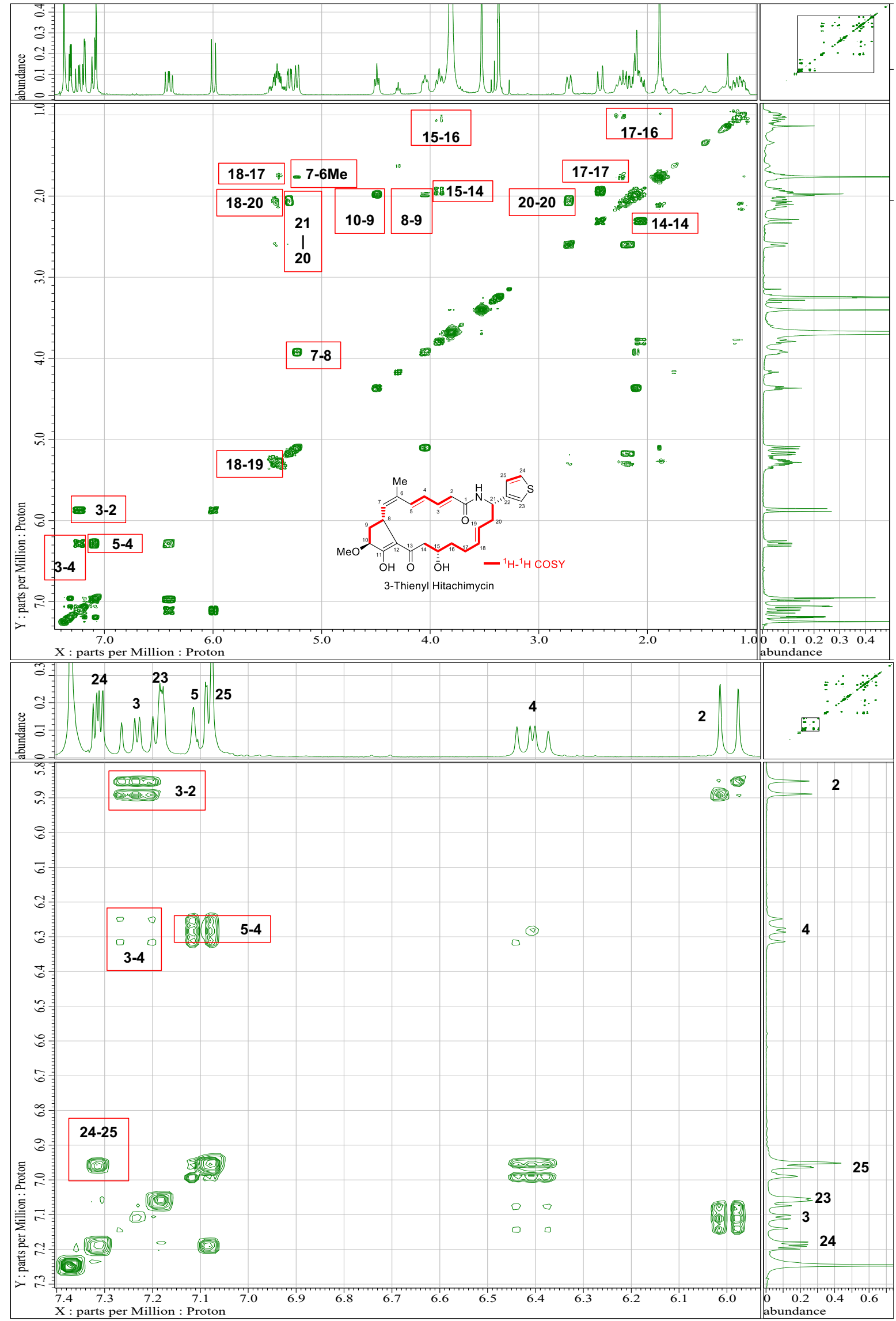


Figure S8-3. ${ }^{13} \mathrm{C}$ NMR spectra of 3-thienyl hitachimycin $(\mathbf{H - 8})\left(125 \mathrm{MHz}\right.$, in $\left.\mathrm{CDCl}_{3}+\mathrm{CD}_{3} \mathrm{OD}\right)$.

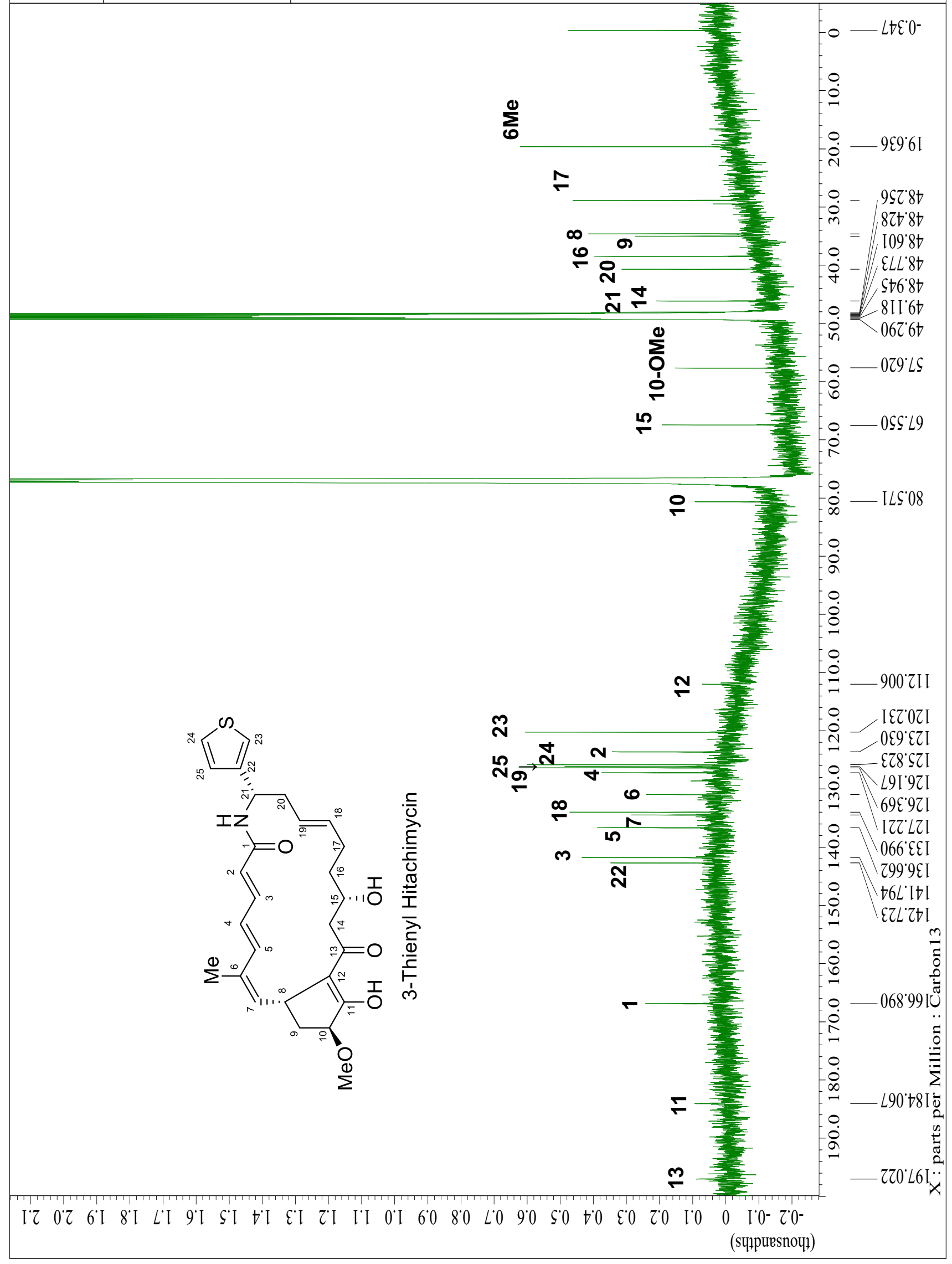


Figure S8-4. HMQC of 3-thienyl hitachimycin (H-8) (in $\left.\mathrm{CDCl}_{3}+\mathrm{CD}_{3} \mathrm{OD}\right)$.

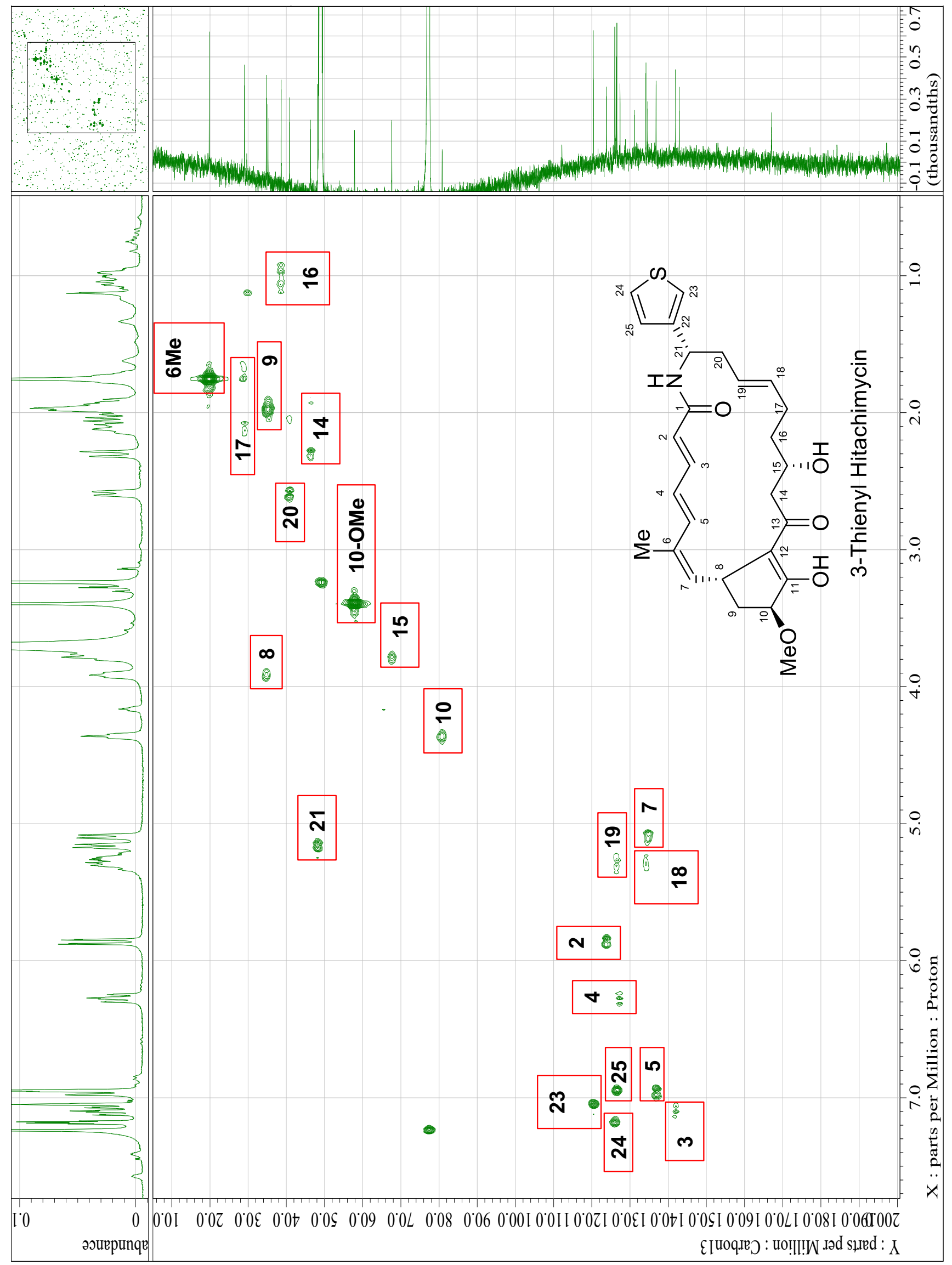


Figure S9-1. ${ }^{1} \mathrm{H}$ NMR spectra of 2-thienyl hitachimycin $(\mathbf{H - 9})\left(400 \mathrm{MHz}\right.$, in $\left.\mathrm{CDCl}_{3}+\mathrm{CD}_{3} \mathrm{OD}\right)$.
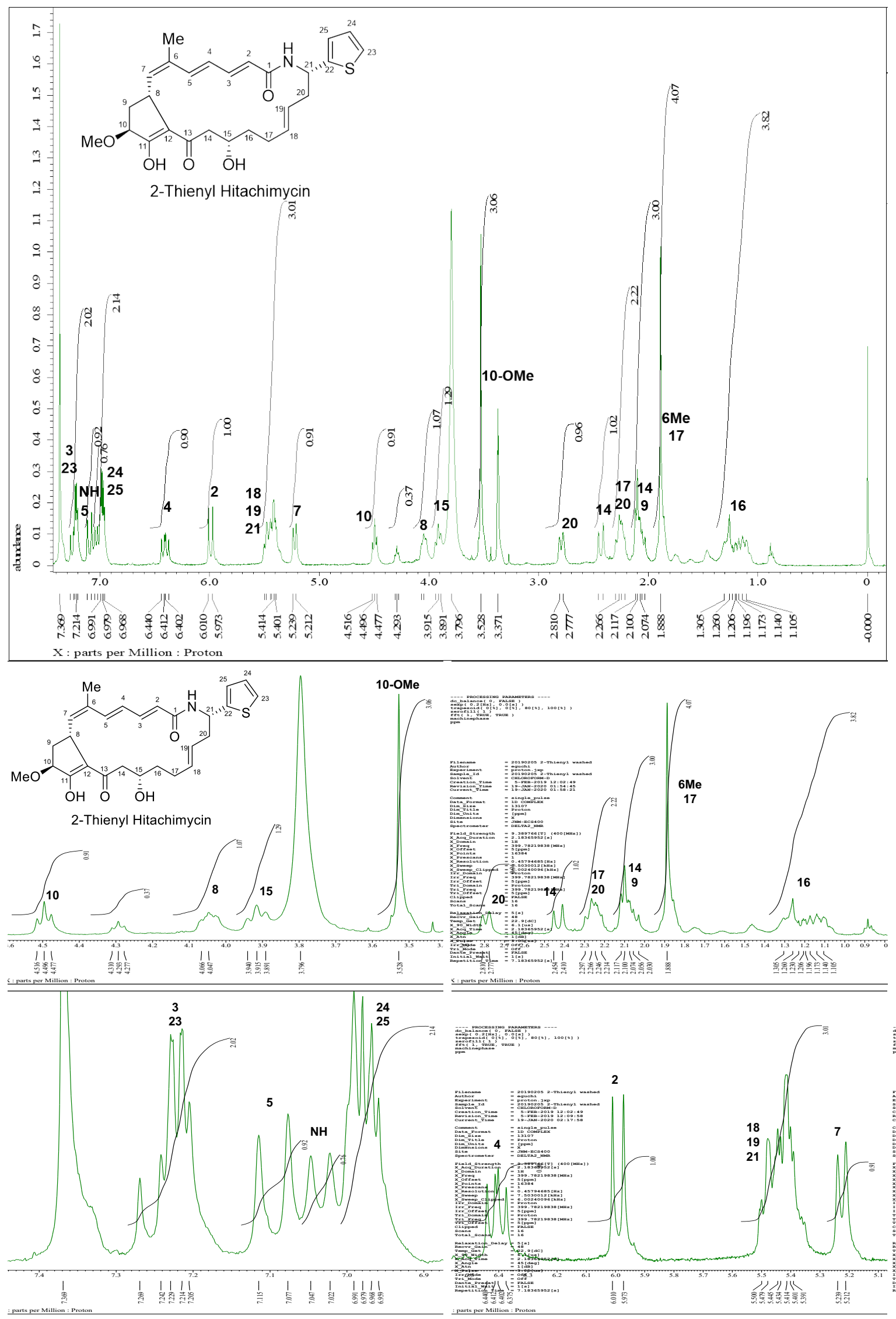
Figure S9-2. ${ }^{1} \mathrm{H}-{ }^{1} \mathrm{H}$ COSY of 2-thienyl hitachimycin (H-9) (in $\mathrm{CDCl}_{3}+\mathrm{CD}_{3} \mathrm{OD}$ ).

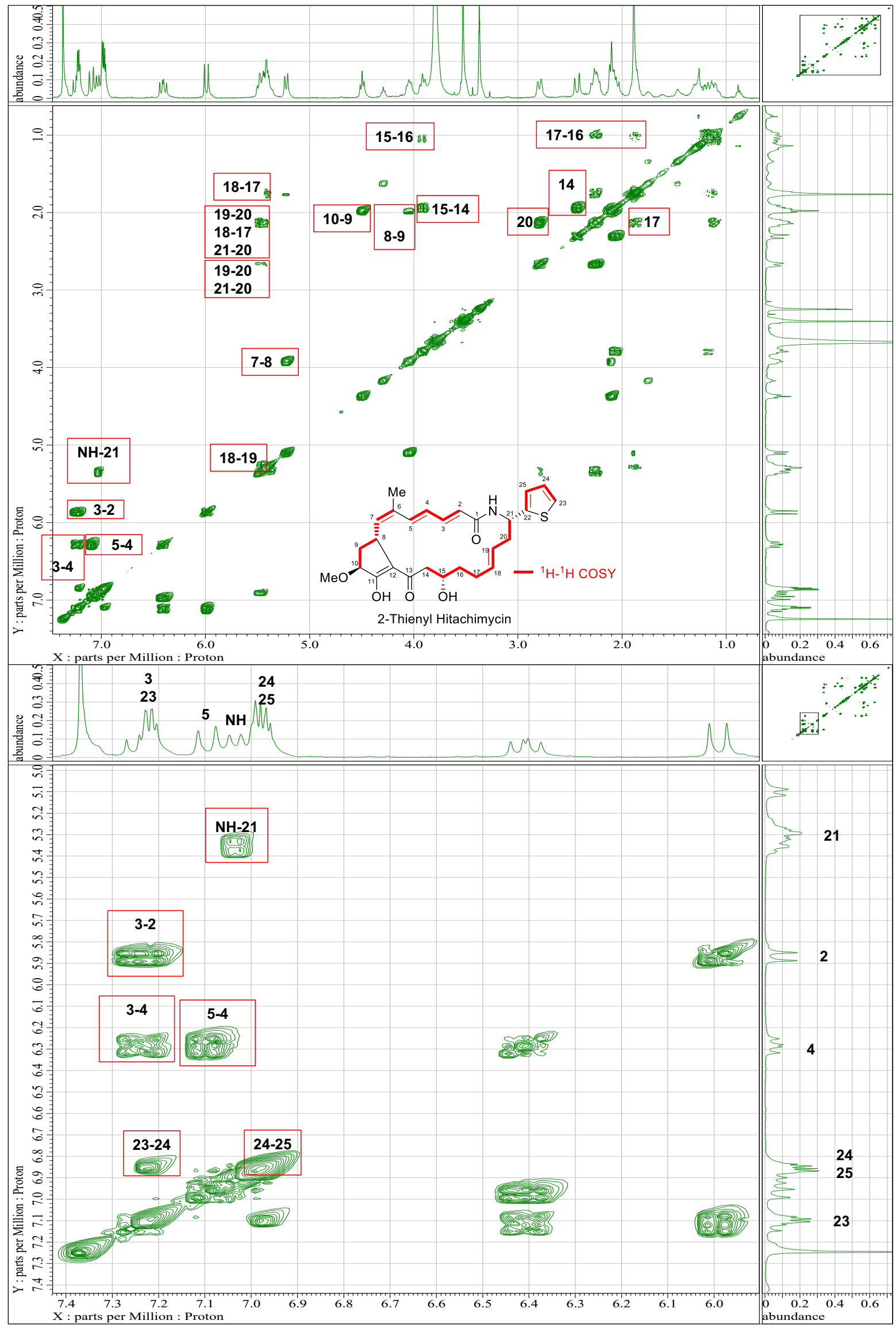


Figure S9-3. ${ }^{13} \mathrm{C}$ NMR spectra of 2-thienyl hitachimycin (H-9) $\left(125 \mathrm{MHz}\right.$ in $\left.\mathrm{CDCl}_{3}+\mathrm{CD}_{3} \mathrm{OD}\right)$.

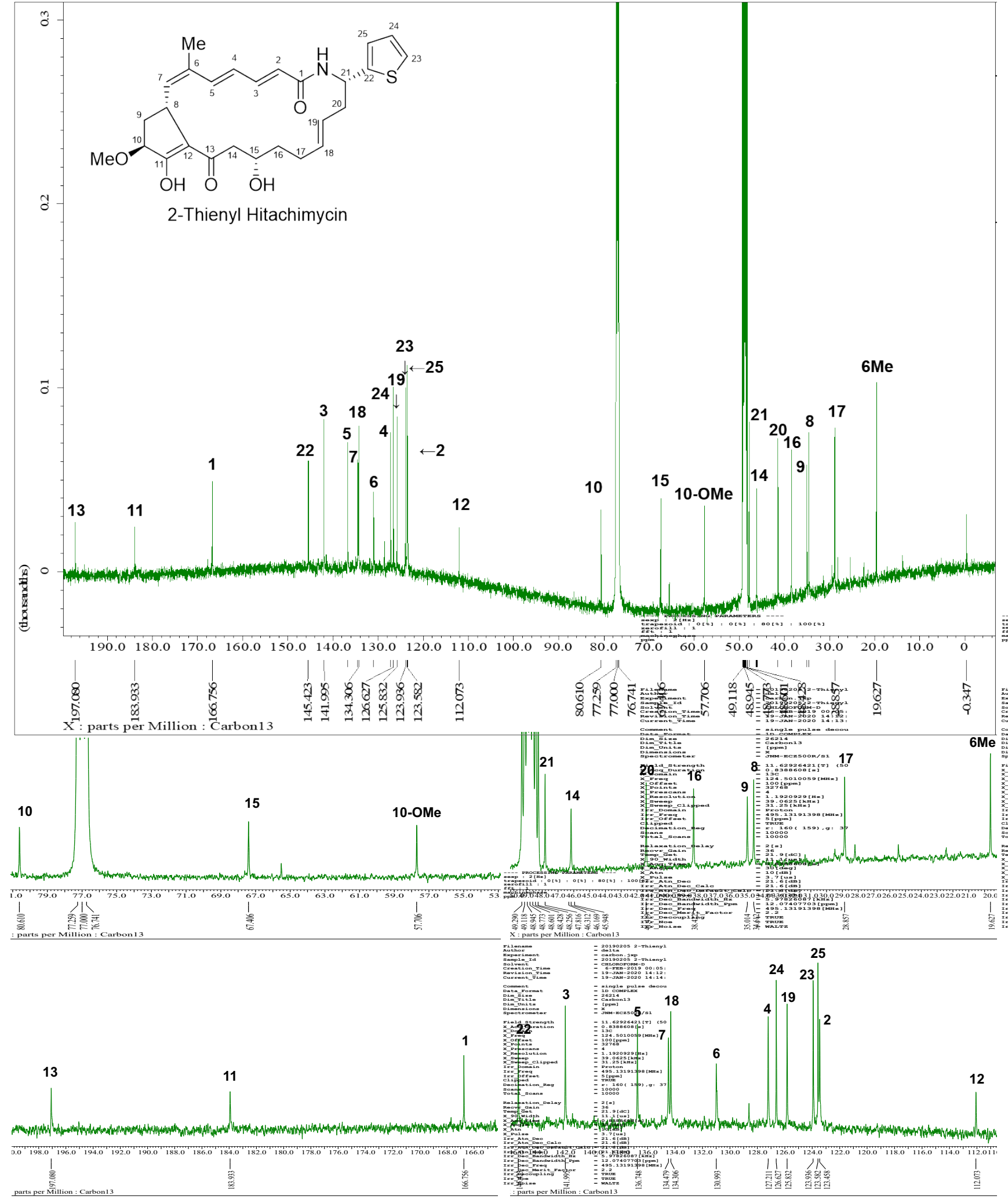


Figure S9-4. HMQC of 2-thienyl hitachimycin (H-9) (in $\mathrm{CDCl}_{3}+\mathrm{CD}_{3} \mathrm{OD}$ ).
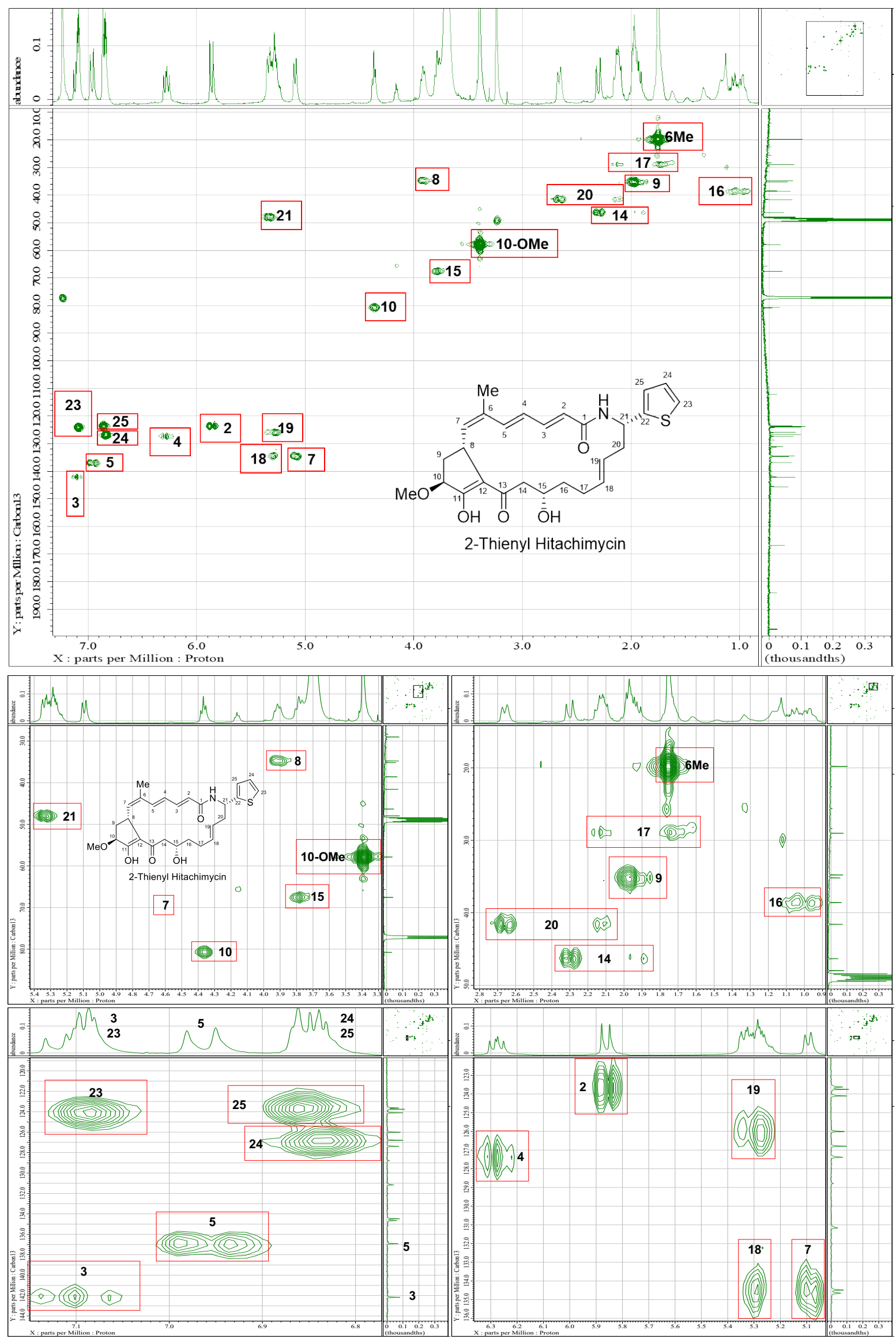
Figure S10. Dimeric structure of HitB.

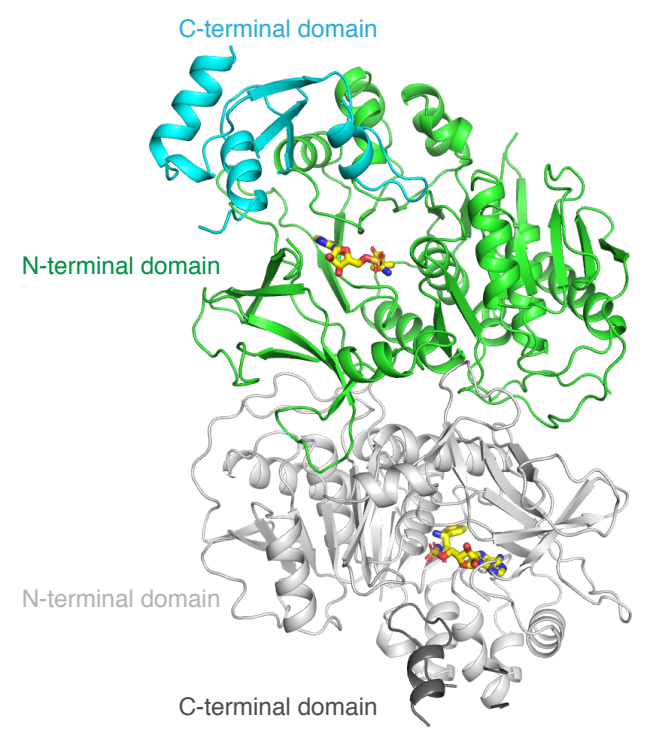

One HitB molecule is shown in green (N-terminal domain) and cyan (C-terminal domain). Another HitB molecule is shown in light gray ( $\mathrm{N}$-terminal domain) and dark gray (C-terminal domain). ( $S$ )- $\beta$-phenylalanine sulfamoyladenosine ( $\beta$-Phe-SA) molecule is shown as yellow sticks. 
Figure S11. Structures of HitB monomer.

A

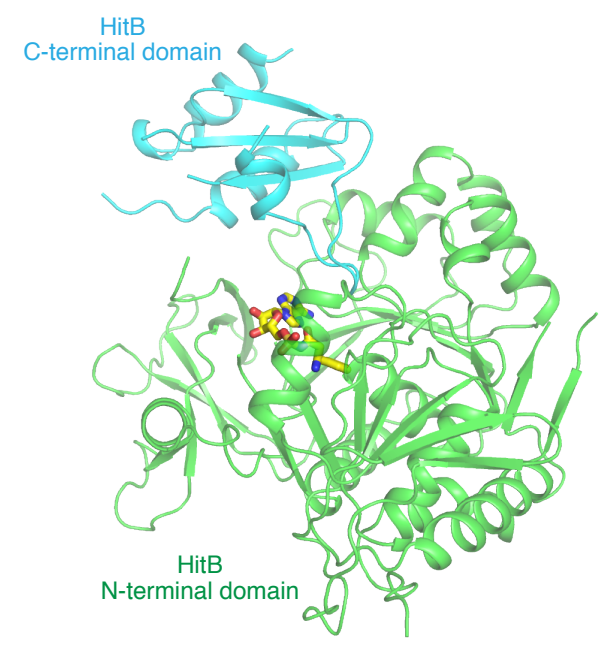

adenylate-forming conformation
B

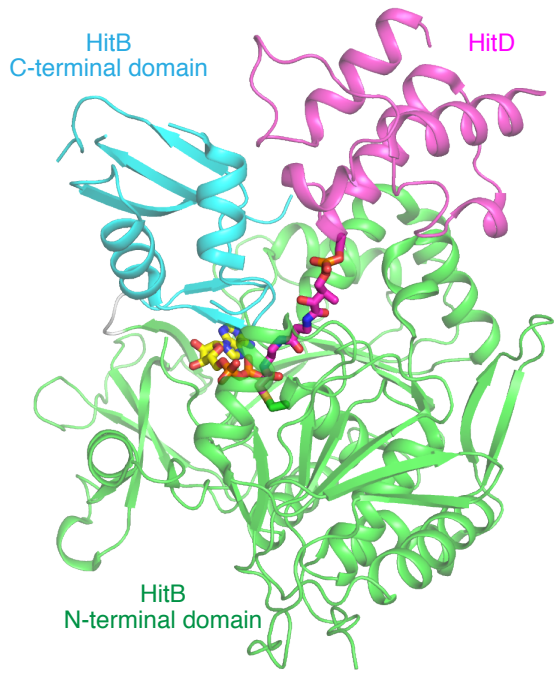

thioester-forming conformation

C

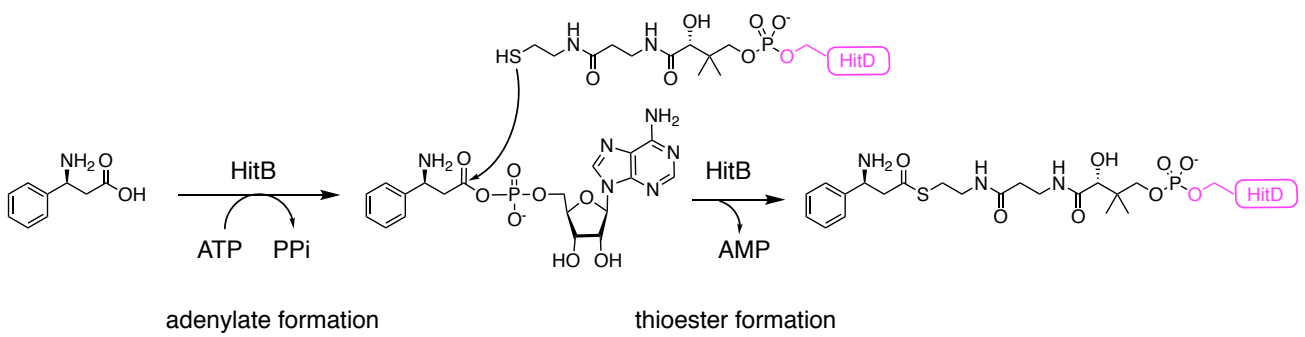

The N-terminal domain and C-terminal domain are shown in green and cyan, respectively. (A) The structure of HitB in complex with $(S)$ - $\beta$-Phe-SA. $\beta$-Phe-SA molecule is shown as yellow sticks. (B) The structure of HitB-HitD cross-linked complex. HitD D221C mutant molecule is shown in magenta. ADP molecule is shown as yellow sticks. Ser36 of HitD, the phosphopantetheine analog moiety, and Cys221 of the HitB D221C mutant are shown as sticks. (C) Reaction of HitB with HitD. 
Figure S12. Adenosine binding site of HitB.

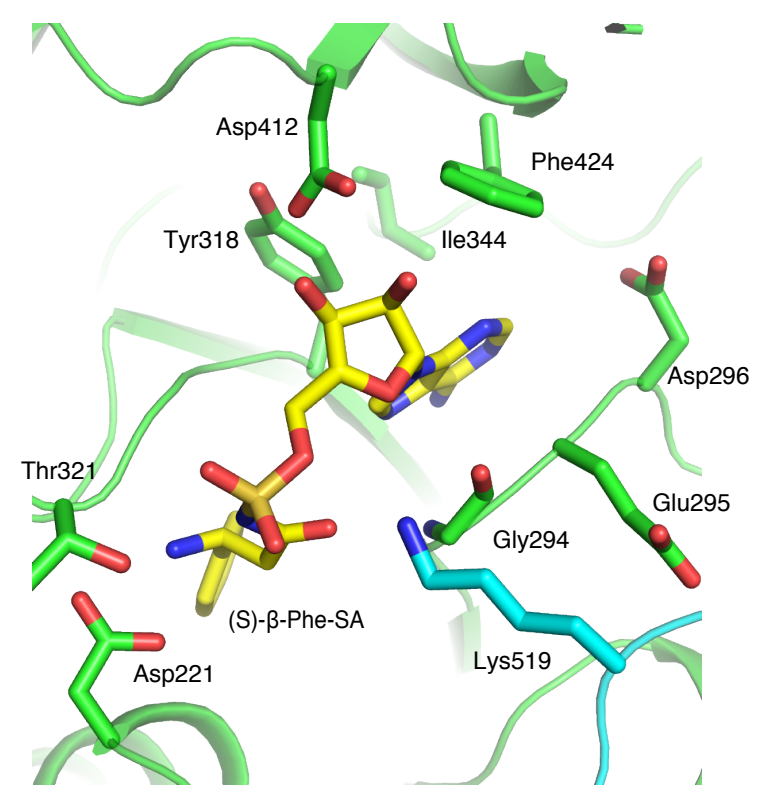

The N-terminal domain and C-terminal domain are shown in green and cyan, respectively. $\beta$-Phe-SA molecule is shown as yellow sticks. 
Figure S13. Structural comparison of the active site of HitB with those of other adenylation enzymes.
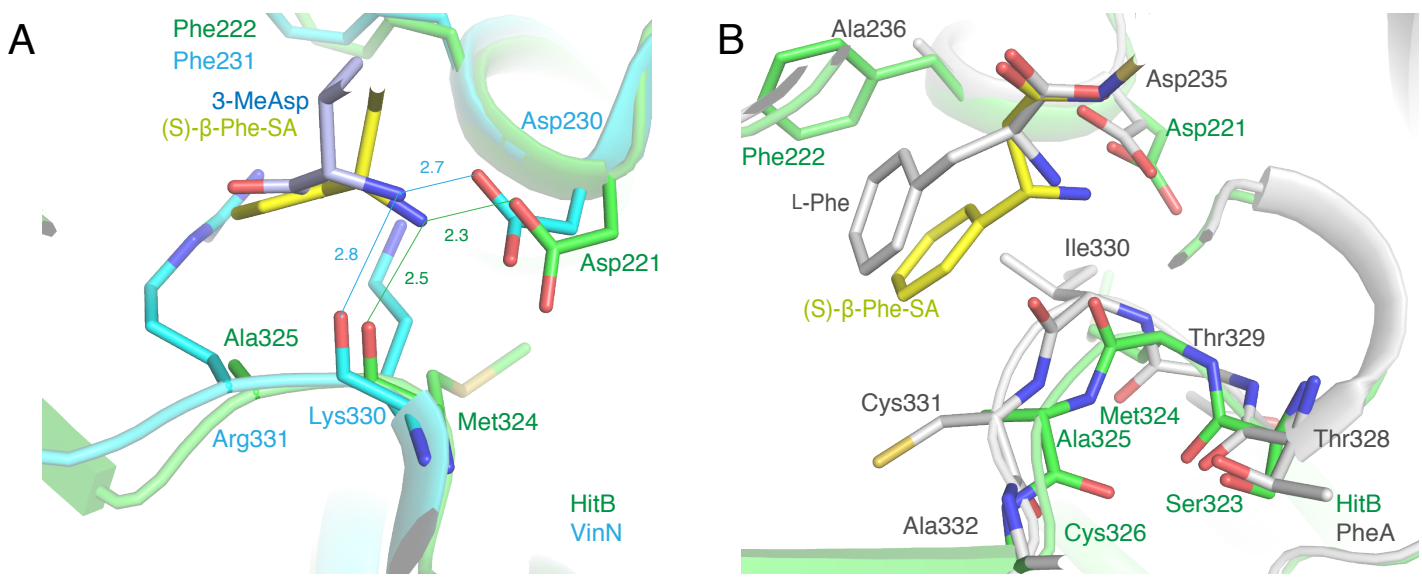

(A) Superimposition of the HitB- $\beta$-Phe-SA complex structure with the VinN-(2S,3S)-3-methylaspartate (3MeAsp) complex structure (PDB ID: 3WV5). The HitB and VinN molecule are shown in green and cyan, respectively. The $\beta$-Phe-SA and 3-MeAsp molecules are shown as yellow and light blue sticks, respectively. The interaction of the $\beta$-amino group of $\beta$-Phe-SA with HitB is shown as green lines. The interaction of the $\beta$ amino group of 3-MeAsp with VinN is shown as cyan lines. HitB has a similar $\beta$-amino acid selective cavity. (B) Superimposition of the HitB- $\beta$-Phe-SA complex structure with the PheA-L-Phe complex structure (PDB ID: 1AMU). The HitB and PheA molecule are shown in green and gray, respectively. The $\beta$-Phe-SA and LPhe molecules are shown as yellow and gray sticks, respectively. The length of substrate binding loop is one residue shorter in HitB (Ser323-Cys326) than L-amino acid adenylation enzymes such as PheA (Thr328Ala332). Additionally, Ala236, adjacent to Asp235, of PheA is replaced by a bulky residue, Phe222, in HitB. 
Figure S14. Comparison of the HitB active site structures.

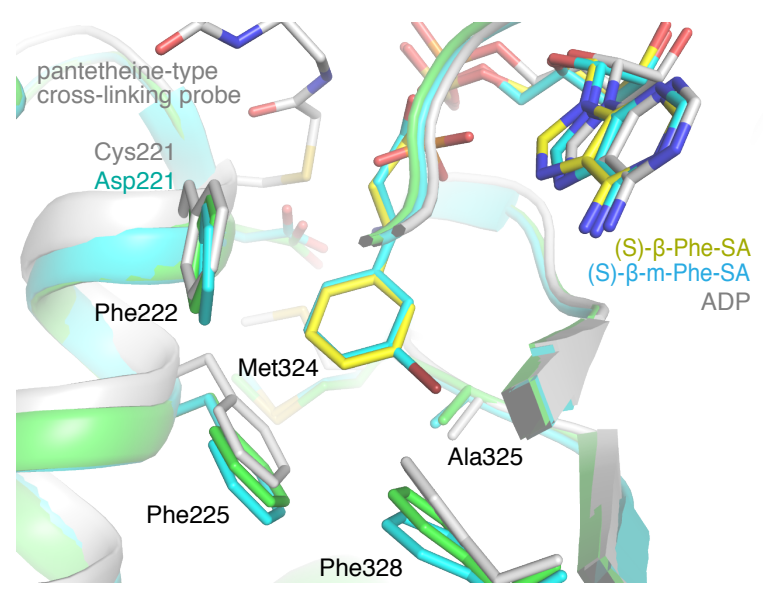

HitB molecule of HitB- $\beta$-Phe-SA complex is shown in green. HitB molecule of HitB- $\beta-m$-Br-Phe-SA complex is shown in cyan. $\beta$-Phe-SA and $\beta-m$-Br-Phe-SA molecules are shown as yellow and cyan sticks, respectively. HitB molecule of HitB-HitD complex is shown in gray. To trap HitB-HitD complex, a bromoacetamide pantetheine cross-linking probe was used in combination with D221C mutation. The position of Phe328 side chain is slightly different among these three structures, suggesting the flexibility of Phe 328 side chain. 
Figure S15. NMR spectra of $(S)-m$-Br- $\beta$-Phe-SA (in $\mathrm{CD}_{3} \mathrm{OD}$ ). A) ${ }^{1} \mathrm{H}-\mathrm{NMR}$. B) ${ }^{13} \mathrm{C}-\mathrm{NMR}$.

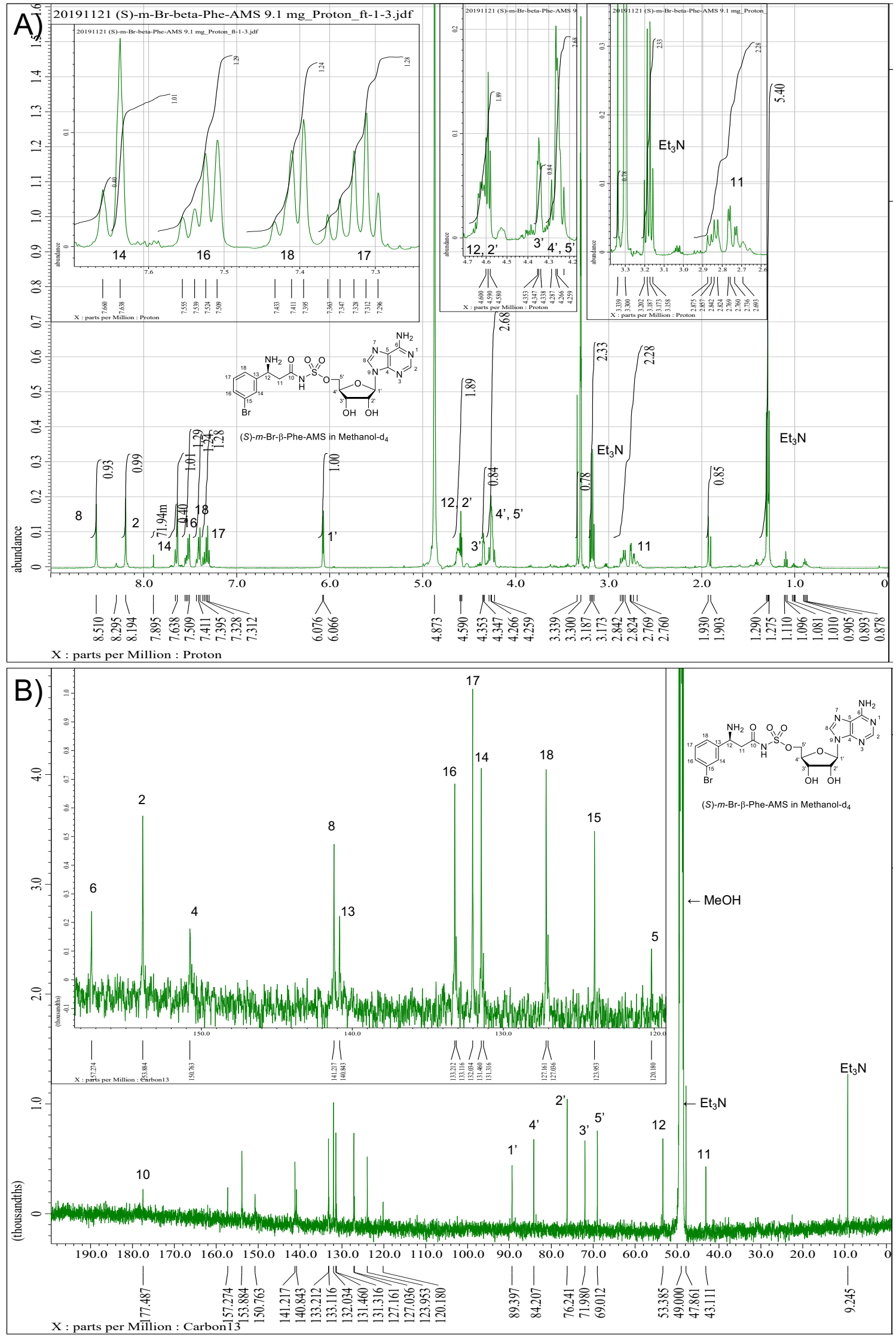


Table S1. NMR data of hitachimycin (H-1) (natural type).

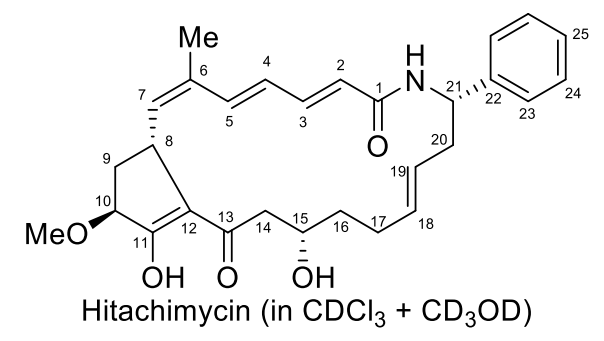

\begin{tabular}{|c|c|c|}
\hline No & $\delta_{\mathrm{H}}(500 \mathrm{MHz}$, Proton; multiplicity; $J / \mathrm{Hz})$ & $\delta \mathrm{c}(125 \mathrm{MHz})$ \\
\hline 1 & - & 167.24 \\
\hline 2 & $6.02(1 \mathrm{H} ; \mathrm{d} ; 15.1)$ & 124.04 \\
\hline 3 & $7.22(1 \mathrm{H} ; \mathrm{dd} ; 11.0,15.1)$ & 141.72 \\
\hline 4 & $6.41(1 \mathrm{H} ; \mathrm{d} ; 11.0,15.1)$ & 127.01 \\
\hline 5 & $7.09(1 \mathrm{H} ; \mathrm{d} ; 15.1)$ & 136.70 \\
\hline 6 & - & 131.08 \\
\hline $6-\mathrm{CH}_{3}$ & $1.89(3 \mathrm{H} ; \mathrm{s})$ & 19.82 \\
\hline $7^{\dagger}$ & $5.22(1 \mathrm{H} ; \mathrm{d} ; 11.5)$ & 134.66 \\
\hline 8 & $4.04(1 \mathrm{H} ; \mathrm{t} ; 16.5)$ & 34.77 \\
\hline 9 & $2.09(2 \mathrm{H} ; \mathrm{m})$ & 35.16 \\
\hline 10 & $4.48(1 \mathrm{H} ; \mathrm{t} ; 15.6)$ & 80.88 \\
\hline $10-\mathrm{OCH}_{3}$ & $3.52(3 \mathrm{H} ; \mathrm{s})$ & 57.83 \\
\hline 11 & - & 184.07 \\
\hline 12 & - & 112.08 \\
\hline 13 & - & 196.95 \\
\hline 14 & $2.44(1 \mathrm{H} ; \mathrm{d} ; 17.4), 2.09(1 \mathrm{H} ; \mathrm{m})$ & 46.19 \\
\hline 15 & $3.93(1 \mathrm{H} ; \mathrm{t} ; 20.2)$ & 67.71 \\
\hline 16 & $1.18(2 \mathrm{H} ; \mathrm{m})$ & 36.71 \\
\hline 17 & $1.89(1 \mathrm{H} ; \mathrm{m}), 2.77(1 \mathrm{H} ; \mathrm{m})$ & 28.92 \\
\hline $18 *$ & $5.43(1 \mathrm{H} ; \mathrm{m})$ & 134.15 \\
\hline $19 *$ & $5.43(1 \mathrm{H} ; \mathrm{m})$ & 126.13 \\
\hline 20 & $2.64(1 \mathrm{H} ; \mathrm{d} ; 13.3), 2.77(1 \mathrm{H} ; \mathrm{m})$ & 41.34 \\
\hline $21^{\dagger}$ & $5.22(1 \mathrm{H} ; \mathrm{d} ; 11.5)$ & 51.80 \\
\hline $\mathrm{NH}$ & $6.99(0.3 \mathrm{H} ; \mathrm{d} ; 10.1)$ & - \\
\hline $22(\mathrm{Ar})$ & - & 141.60 \\
\hline $23(\mathrm{Ar})$ & $7.31(1 \mathrm{H} ; \mathrm{m})$ & 126.44 \\
\hline $24(\mathrm{Ar})$ & $7.31(1 \mathrm{H} ; \mathrm{m})$ & 128.36 \\
\hline 25 (Ar) & $7.31(1 \mathrm{H} ; \mathrm{m})$ & 127.31 \\
\hline
\end{tabular}

$\dagger, ※$ : Signals were overlapped. 
Table S2. NMR data of $o$-F-phenyl hitachimycin (H-2).

\begin{tabular}{|c|c|c|}
\hline No & $\delta_{\mathrm{H}}(400 \mathrm{MHz} ;$ multiplicity; $J / \mathrm{Hz})$ & $\delta_{\mathrm{C}}(125 \mathrm{MHz} ;$ multiplicity; $\mathrm{J} / \mathrm{Hz})$ \\
\hline 1 & - & 166.89 \\
\hline 2 & $6.03(1 \mathrm{H} ; \mathrm{d} ; 15.1)$ & 123.68 \\
\hline 3 & $7.22(1 \mathrm{H} ; \mathrm{dd} ; 11.0,14.7)$ & 141.81 \\
\hline 4 & $6.41(1 \mathrm{H} ; \mathrm{dd} ; 11.5,15.6)$ & 127.21 \\
\hline 5 & $7.09(1 \mathrm{H} ; \mathrm{m})$ & 136.62 \\
\hline 6 & - & 130.97 \\
\hline $6-\mathrm{CH}_{3}$ & $1.89(3 \mathrm{H} ; \mathrm{s})$ & 19.64 \\
\hline 7 & $5.23(1 \mathrm{H} ; \mathrm{d} ; 11.0)$ & 134.48 \\
\hline 8 & $4.05(1 \mathrm{H} ; \mathrm{t} ; 15.1)$ & 34.56 \\
\hline 9 & $2.10(2 \mathrm{H} ; \mathrm{m})$ & 35.00 \\
\hline 10 & $4.50(1 \mathrm{H} ; \mathrm{t} ; 15.6)$ & 80.60 \\
\hline $10-\mathrm{OCH}_{3}$ & $3.53(3 \mathrm{H} ; \mathrm{s})$ & 57.70 \\
\hline 11 & - & 184.20 \\
\hline 12 & - & 112.05 \\
\hline 13 & - & 196.79 \\
\hline 14 & $2.44(1 \mathrm{H} ; \mathrm{d} ; 17.4), 2.10(1 \mathrm{H} ; \mathrm{m})$ & 46.13 \\
\hline 15 & $3.93(1 \mathrm{H} ; \mathrm{t} ; 20.2)$ & 67.45 \\
\hline 16 & $1.19(2 \mathrm{H} ; \mathrm{m})$ & 38.50 \\
\hline 17 & $1.89(1 \mathrm{H} ; \mathrm{m}), 2.25(1 \mathrm{H} ; \mathrm{m})$ & 28.92 \\
\hline 18 & $5.44(1 \mathrm{H} ; \mathrm{m})$ & 134.26 \\
\hline 19 & $5.44(1 \mathrm{H} ; \mathrm{m})$ & 126.10 \\
\hline 20 & $2.25(1 \mathrm{H} ; \mathrm{m}), 2.55(1 \mathrm{H} ; \mathrm{d} ; 12.8)$ & 40.59 \\
\hline 21 & $5.44(1 \mathrm{H} ; \mathrm{m})$ & 48.11 \\
\hline $\mathrm{NH}$ & $6.90(0.6 \mathrm{H} ; \mathrm{d} ; 10.5)$ & - \\
\hline 22 & - & $128.53(\mathrm{~d} ; 14.3)$ \\
\hline 23 & - & $160.33(\mathrm{~d} ; 245.6)$ \\
\hline 24 & $7.07(1 \mathrm{H} ; \mathrm{m})$ & $115.52(\mathrm{~d} ; 22.7)$ \\
\hline 25 & $7.28(1 \mathrm{H} ; \mathrm{m})$ & $128.76(\mathrm{~d} ; 8.34)$ \\
\hline 26 & $7.13(1 \mathrm{H} ; \mathrm{m})$ & $124.11(\mathrm{~d} ; 3.60)$ \\
\hline 27 & $7.35(1 \mathrm{H} ; \mathrm{m})$ & $127.85(\mathrm{~d} ; 4.77)$ \\
\hline
\end{tabular}


Table S3. NMR data of $m$-F-phenyl hitachimycin (H-3).

\begin{tabular}{|c|c|c|}
\hline No & $\delta_{\mathrm{H}}(400 \mathrm{MHz} ;$ multiplicity; $J / \mathrm{Hz})$ & $\delta_{\mathrm{C}}(125 \mathrm{MHz}$; multiplicity; $\mathrm{J} / \mathrm{Hz})$ \\
\hline 1 & - & 167.15 \\
\hline 2 & $6.03(1 \mathrm{H} ; \mathrm{d} ; 15.1)$ & 123.80 \\
\hline 3 & $7.22(1 \mathrm{H} ; \mathrm{dd} ; 11.0,15.1)$ & 136.55 \\
\hline 4 & $6.41(1 \mathrm{H} ; \mathrm{dd} ; 11.5,15.1)$ & 127.31 \\
\hline 5 & $7.11(1 \mathrm{H} ; \mathrm{m})$ & 136.55 \\
\hline 6 & - & 131.00 \\
\hline $6-\mathrm{CH}_{3}$ & $1.89(3 \mathrm{H} ; \mathrm{s})$ & 19.66 \\
\hline 7 & $5.23(1 \mathrm{H} ; \mathrm{m})$ & 134.43 \\
\hline 8 & $4.04(1 \mathrm{H} ; \mathrm{dt} ; 20.6,2.8)$ & 34.60 \\
\hline 9 & $2.12(2 \mathrm{H} ; \mathrm{m})$ & 35.01 \\
\hline 10 & $4.49(1 \mathrm{H} ; \mathrm{t} ; 15.6)$ & 80.64 \\
\hline $10-\mathrm{OCH}_{3}$ & $3.53(3 \mathrm{H} ; \mathrm{s})$ & 57.69 \\
\hline 11 & - & 184.21 \\
\hline 12 & - & 112.05 \\
\hline 13 & - & 196.82 \\
\hline 14 & $2.44(1 \mathrm{H} ; \mathrm{dd} ; 17.4,18.8), 2.12(1 \mathrm{H} ; \mathrm{m})$ & 46.19 \\
\hline 15 & $3.93(1 \mathrm{H} ; \mathrm{t} ; 20.2)$ & 67.47 \\
\hline 16 & $1.18(2 \mathrm{H} ; \mathrm{m})$ & 38.49 \\
\hline 17 & $1.89(1 \mathrm{H} ; \mathrm{m}), 2.27(1 \mathrm{H} ; \mathrm{t} ; 25.7)$ & 28.92 \\
\hline 18 & $5.43(1 \mathrm{H} ; \mathrm{m})$ & 134.25 \\
\hline 19 & $5.43(1 \mathrm{H} ; \mathrm{m})$ & 126.08 \\
\hline 20 & $2.12(1 \mathrm{H} ; \mathrm{m}), 2.62(1 \mathrm{H} ; \mathrm{d} ; 12.4)$ & 41.01 \\
\hline 21 & $5.23(1 \mathrm{H} ; \mathrm{m})$ & 51.44 \\
\hline $\mathrm{NH}$ & $7.11(1 \mathrm{H} ; \mathrm{m})$ & - \\
\hline 22 & - & $128.53(\mathrm{~d} ; 14.3)$ \\
\hline 23 & $7.07(1 \mathrm{H} ; \mathrm{s})$ & $160.33(\mathrm{~d} ; 245.6)$ \\
\hline 24 & - & $115.52(\mathrm{~d} ; 22.7)$ \\
\hline 25 & $6.96(1 \mathrm{H} ; \mathrm{dt} ; 16.9,2.8)$ & $128.76(\mathrm{~d} ; 8.34)$ \\
\hline 26 & $7.32(1 \mathrm{H} ; \mathrm{m})$ & $124.11(\mathrm{~d} ; 3.60)$ \\
\hline 27 & $7.11(1 \mathrm{H} ; \mathrm{mSo})$ & $127.85(\mathrm{~d} ; 4.77)$ \\
\hline
\end{tabular}


Table S4. NMR data of $p$-F-phenyl hitachimycin (H-4).

\begin{tabular}{|c|c|c|}
\hline No & $\delta$ н (400 MHz; multiplicity; $J / \mathrm{Hz})$ & $\delta_{\mathrm{C}}(125 \mathrm{MHz} ;$ multiplicity; $\mathrm{J} / \mathrm{Hz})$ \\
\hline 1 & - & 167.01 \\
\hline 2 & $6.01(1 \mathrm{H} ; \mathrm{d} ; 15.1)$ & 123.83 \\
\hline 3 & $7.21(1 \mathrm{H} ; \mathrm{dd} ; 11.0,15.1)$ & 141.55 \\
\hline 4 & $6.40(1 \mathrm{H} ; \mathrm{dd} ; 11.0,15.1)$ & 127.29 \\
\hline 5 & $7.07(1 \mathrm{H} ; \mathrm{m})$ & 136.52 \\
\hline 6 & - & 130.98 \\
\hline $6-\mathrm{CH}_{3}$ & $1.89(3 \mathrm{H} ; \mathrm{s})$ & 19.66 \\
\hline 7 & $5.21(1 \mathrm{H} ; \mathrm{m})$ & 134.43 \\
\hline 8 & $4.03(1 \mathrm{H} ; \mathrm{t} ; 18.8)$ & 34.60 \\
\hline 9 & $2.16(2 \mathrm{H} ; \mathrm{m})$ & 35.01 \\
\hline 10 & $4.48(1 \mathrm{H} ; \mathrm{t} ; 15.6)$ & 80.62 \\
\hline $10-\mathrm{OCH}_{3}$ & $3.52(3 \mathrm{H} ; \mathrm{s})$ & 57.70 \\
\hline 11 & - & 184.14 \\
\hline 12 & - & 112.06 \\
\hline 13 & - & 196.88 \\
\hline 14 & $2.43(1 \mathrm{H} ; \mathrm{d} ; 12.4), 2.16(1 \mathrm{H} ; \mathrm{m})$ & 46.19 \\
\hline 15 & $3.92(1 \mathrm{H} ; \mathrm{t} ; 19.7)$ & 67.46 \\
\hline 16 & $1.19(2 \mathrm{H} ; \mathrm{m})$ & 38.51 \\
\hline 17 & $1.89(1 \mathrm{H} ; \mathrm{m}), 2.16(1 \mathrm{H} ; \mathrm{m})$ & 28.92 \\
\hline 18 & $5.42(1 \mathrm{H} ; \mathrm{m})$ & 134.11 \\
\hline 19 & $5.42(1 \mathrm{H} ; \mathrm{m})$ & 126.23 \\
\hline 20 & $2.16(1 \mathrm{H} ; \mathrm{m}), 2.61(1 \mathrm{H} ; \mathrm{d} ; 12.4)$ & 41.08 \\
\hline 21 & $5.21(1 \mathrm{H} ; \mathrm{m})$ & 48.15 \\
\hline NH & $7.07(1 \mathrm{H} ; \mathrm{m})$ & - \\
\hline 22 & - & $137.51(\mathrm{~d} ; 2.4)$ \\
\hline 23 & $7.33(2 \mathrm{H} ; \mathrm{dd} ; 5.5,8.7)$ & $127.80(\mathrm{~d} ; 8.3)$ \\
\hline 24 & $7.07(2 \mathrm{H} ; \mathrm{m})$ & $115.07(\mathrm{~d} ; 22.5)$ \\
\hline 25 & - & $161.70(\mathrm{~d} ; 245.6)$ \\
\hline
\end{tabular}


Table S5. NMR data of $m$-Cl-phenyl hitachimycin (H-5).

\begin{tabular}{|c|c|c|}
\hline No & $\delta_{\mathrm{H}}(400 \mathrm{MHz}$, Proton; multiplicity; $\mathrm{J} / \mathrm{Hz})$ & $\delta_{\mathrm{C}}(125 \mathrm{MHz})$ \\
\hline 1 & - & 167.15 \\
\hline 2 & $6.04(1 \mathrm{H} ; \mathrm{d} ; 15.1)$ & 123.72 \\
\hline 3 & $7.27(1 \mathrm{H} ; \mathrm{m})$ & 141.70 \\
\hline 4 & $6.41(1 \mathrm{H} ; \mathrm{dd} ; 11.0,15.1)$ & 127.08 \\
\hline 5 & $7.09(1 \mathrm{H} ; \mathrm{d} ; 15.6)$ & 136.64 \\
\hline 6 & - & Not detected \\
\hline $6-\mathrm{CH}_{3}$ & $1.89(3 \mathrm{H} ; \mathrm{s})$ & 19.67 \\
\hline 7 & $5.23(1 \mathrm{H} ; \mathrm{d} ; 11.5)$ & 134.68 \\
\hline 8 & $4.03(1 \mathrm{H} ; \mathrm{t} ; 17.9)$ & 34.64 \\
\hline 9 & $2.10(2 \mathrm{H} ; \mathrm{m})$ & 34.99 \\
\hline 10 & $4.47(1 \mathrm{H} ; \mathrm{t} ; 15.61)$ & 80.78 \\
\hline $10-\mathrm{OCH} 3$ & $3.52(3 \mathrm{H} ; \mathrm{s})$ & 57.60 \\
\hline 11 & - & Not detected \\
\hline 12 & - & 115.50 \\
\hline 13 & - & 196.69 \\
\hline 14 & $2.42(1 \mathrm{H} ; \mathrm{d} ; 17.9), 2.10(2 \mathrm{H} ; \mathrm{m})$ & 46.15 \\
\hline 15 & $3.92(1 \mathrm{H} ; \mathrm{t} ; 21.5)$ & 67.56 \\
\hline 16 & $1.24(2 \mathrm{H} ; \mathrm{m})$ & 38.51 \\
\hline 17 & $1.89(1 \mathrm{H} ; \mathrm{m}), 2.26(1 \mathrm{H} ; \mathrm{t} ; 24.3)$ & 28.92 \\
\hline 18 & $5.42(1 \mathrm{H} ; \mathrm{m})$ & 134.33 \\
\hline 19 & $5.42(1 \mathrm{H} ; \mathrm{m})$ & 126.02 \\
\hline 20 & $2.61(1 \mathrm{H} ; \mathrm{d} ; 11.9), 2.10(2 \mathrm{H} ; \mathrm{m})$ & 41.01 \\
\hline 21 & $5.18(1 \mathrm{H} ; \mathrm{dd} ; 2.8,11.9)$ & 51.42 \\
\hline $\mathrm{NH}$ & $7.27(1 \mathrm{H} ; \mathrm{m})$ & - \\
\hline 22 & - & 143.88 \\
\hline 23 & $7.27(1 \mathrm{H} ; \mathrm{m})$ & 126.30 \\
\hline 24 & - & 134.17 \\
\hline 25 & $7.27(1 \mathrm{H} ; \mathrm{m})$ & 124.51 \\
\hline 26 & $7.27(1 \mathrm{H} ; \mathrm{m})$ & 129.66 \\
\hline 27 & $7.27(1 \mathrm{H} ; \mathrm{m})$ & 127.23 \\
\hline
\end{tabular}


Table S6. NMR data of $m$-Br-phenyl hitachimycin (H-6).

\begin{tabular}{|c|c|c|}
\hline No & $\delta_{\mathrm{H}}(400 \mathrm{MHz}$ Proton; multiplicity; $\mathrm{J} / \mathrm{Hz})$ & $\delta_{\mathrm{C}}(125 \mathrm{MHz})$ \\
\hline 1 & - & 167.10 \\
\hline 2 & $6.03(1 \mathrm{H} ; \mathrm{d} ; 15.1)$ & 123.76 \\
\hline 3 & $7.21(1 \mathrm{H} ; \mathrm{m})$ & 141.61 \\
\hline 4 & $6.41(1 \mathrm{H} ; \mathrm{dd} ; 11.5,15.1)$ & 127.30 \\
\hline 5 & $7.08(1 \mathrm{H} ; \mathrm{d} ; 15.1)$ & 136.57 \\
\hline 6 & - & 130.98 \\
\hline $6-\mathrm{CH}_{3}$ & $1.89(3 \mathrm{H} ; \mathrm{s})$ & 19.68 \\
\hline 7 & $5.20(1 \mathrm{H} ; \mathrm{m})$ & 134.41 \\
\hline 8 & $4.04(1 \mathrm{H} ; \mathrm{t} ; 18.3)$ & 34.61 \\
\hline 9 & $2.16(2 \mathrm{H} ; \mathrm{m})$ & 35.01 \\
\hline 10 & $4.50(1 \mathrm{H} ; \mathrm{t} ; 15.1)$ & 80.61 \\
\hline $10-\mathrm{OCH}_{3}$ & $3.53(3 \mathrm{H} ; \mathrm{s})$ & 57.71 \\
\hline 11 & - & 183.90 \\
\hline 12 & - & 112.06 \\
\hline 13 & - & 197.03 \\
\hline 14 & $2.43(1 \mathrm{H} ; \mathrm{d} ; 17.4), 2.16(1 \mathrm{H} ; \mathrm{m})$ & 46.23 \\
\hline 15 & $3.93(1 \mathrm{H} ; \mathrm{t} ; 20.2)$ & 67.43 \\
\hline 16 & $1.19(2 \mathrm{H} ; \mathrm{m})$ & 38.47 \\
\hline 17 & $1.89(1 \mathrm{H} ; \mathrm{m}), 2.26(1 \mathrm{H} ; \mathrm{t} ; 25.2)$ & 28.92 \\
\hline 18 & $5.42(1 \mathrm{H} ; \mathrm{m})$ & 134.29 \\
\hline 19 & $5.42(1 \mathrm{H} ; \mathrm{m})$ & 126.02 \\
\hline 20 & $2.61(1 \mathrm{H} ; \mathrm{d} ; 13.3), 2.16(1 \mathrm{H} ; \mathrm{m})$ & 41.03 \\
\hline 21 & $5.20(1 \mathrm{H} ; \mathrm{m})$ & 51.37 \\
\hline $\mathrm{NH}$ & $7.21(1 \mathrm{H} ; \mathrm{m})$ & - \\
\hline 22 & - & 144.13 \\
\hline 23 & $7.52(1 \mathrm{H} ; \mathrm{s})$ & 129.21 \\
\hline 24 & - & 122.40 \\
\hline 25 & $7.30(1 \mathrm{H} ; \mathrm{d} ; 7.8)$ & 130.02 \\
\hline 26 & $7.21(1 \mathrm{H} ; \mathrm{m})$ & 129.95 \\
\hline 27 & $7.40(1 \mathrm{H} ; \mathrm{d} ; 7.8)$ & 124.98 \\
\hline
\end{tabular}


Table S7. NMR data of $m$-Me-phenyl hitachimycin (H-7).

\begin{tabular}{|c|c|c|}
\hline No & $\delta_{\mathrm{H}}(400 \mathrm{MHz}$ Proton; multiplicity; $J / \mathrm{Hz})$ & $\delta_{\mathrm{C}}(125 \mathrm{MHz})$ \\
\hline 1 & - & 168.95 \\
\hline 2 & $6.02(1 \mathrm{H} ; \mathrm{d} ; 15.1)$ & 123.93 \\
\hline 3 & $7.23(1 \mathrm{H} ; \mathrm{m})$ & 141.52 \\
\hline 4 & $6.41(1 \mathrm{H} ; \mathrm{dd} ; 11.0,15.1)$ & 127.31 \\
\hline 5 & $7.09(1 \mathrm{H} ; \mathrm{m})$ & 136.47 \\
\hline 6 & - & 131.00 \\
\hline $6-\mathrm{CH}_{3}$ & $1.89(3 \mathrm{H} ; \mathrm{s})$ & 19.66 \\
\hline 7 & $5.20(1 \mathrm{H} ; \mathrm{m})$ & 134.37 \\
\hline 8 & $4.05(1 \mathrm{H} ; \mathrm{t} ; 15.1)$ & 34.59 \\
\hline 9 & $2.16(1 \mathrm{H} ; \mathrm{m})$ & 35.01 \\
\hline 10 & $4.50(1 \mathrm{H} ; \mathrm{t} ; 15.1)$ & 80.49 \\
\hline $10-\mathrm{OCH}_{3}$ & $3.53(3 \mathrm{H} ; \mathrm{s})$ & 57.55 \\
\hline 11 & - & 184.08 \\
\hline 12 & - & 112.08 \\
\hline 13 & - & 196.91 \\
\hline 14 & $2.44(1 \mathrm{H} ; \mathrm{d} ; 17.4), 2.16(1 \mathrm{H} ; \mathrm{m})$ & 46.18 \\
\hline 15 & $3.93(1 \mathrm{H} ; \mathrm{t} ; 19.2)$ & 67.47 \\
\hline 16 & $1.24(2 \mathrm{H} ; \mathrm{m})$ & 38.53 \\
\hline 17 & $1.89(1 \mathrm{H} ; \mathrm{m}), 2.16(1 \mathrm{H} ; \mathrm{m})$ & 28.92 \\
\hline 18 & $5.43(1 \mathrm{H} ; \mathrm{m})$ & 133.89 \\
\hline 19 & $5.43(1 \mathrm{H} ; \mathrm{m})$ & 126.49 \\
\hline 20 & $2.62(1 \mathrm{H} ; \mathrm{d} ; 13.3), 2.16(1 \mathrm{H} ; \mathrm{m})$ & 41.26 \\
\hline 21 & $5.20(1 \mathrm{H} ; \mathrm{m})$ & 51.81 \\
\hline $\mathrm{NH}$ & $6.93(1 \mathrm{H} ; \mathrm{d} ; 10.53)$ & - \\
\hline 22 & - & 141.52 \\
\hline 23 & $7.15(1 \mathrm{H} ; \mathrm{m})$ & 126.95 \\
\hline 24 & - & 138.04 \\
\hline $24-\mathrm{CH}_{3}$ & $2.36(3 \mathrm{H} ; \mathrm{s})$ & 21.11 \\
\hline 25 & $7.15(1 \mathrm{H} ; \mathrm{m})$ & 123.07 \\
\hline 26 & $7.15(1 \mathrm{H} ; \mathrm{m})$ & 128.27 \\
\hline 27 & $7.15(1 \mathrm{H} ; \mathrm{m})$ & 127.74 \\
\hline
\end{tabular}


Table S8. NMR data of 3-thienyl hitachimycin (H-8).

\begin{tabular}{|c|c|c|}
\hline No & $\delta_{\mathrm{H}}(400 \mathrm{MHz} ;$ multiplicity; $J / \mathrm{Hz})$ & $\delta_{\mathrm{C}}(125 \mathrm{MHz} ;$ multiplicity; $J / \mathrm{Hz})$ \\
\hline 1 & - & 166.89 \\
\hline 2 & $6.00(1 \mathrm{H} ; \mathrm{d} ; 14.7)$ & 123.63 \\
\hline 3 & $7.25(1 \mathrm{H} ; \mathrm{dd} ; 11.0,15.1)$ & 141.79 \\
\hline 4 & $6.41(1 \mathrm{H} ; \mathrm{dd} ; 11.0,15.1)$ & 127.22 \\
\hline 5 & $7.10(1 \mathrm{H} ; \mathrm{m})$ & 136.66 \\
\hline 6 & - & 131.00 \\
\hline $6-\mathrm{CH}_{3}$ & $1.89(3 \mathrm{H} ; \mathrm{s})$ & 19.64 \\
\hline 7 & $5.23(1 \mathrm{H} ; \mathrm{d} ; 11.0)$ & 134.48 \\
\hline 8 & $4.05(1 \mathrm{H} ; \mathrm{t} ; 15.6)$ & 34.61 \\
\hline 9 & $2.09(2 \mathrm{H} ; \mathrm{m})$ & 35.01 \\
\hline 10 & $4.49(1 \mathrm{H} ; \mathrm{t} ; 15.6)$ & 80.57 \\
\hline $10-\mathrm{OCH} 3$ & $3.53(3 \mathrm{H} ; \mathrm{s})$ & 57.62 \\
\hline 11 & - & 184.07 \\
\hline 12 & - & 112.01 \\
\hline 13 & - & 197.02 \\
\hline 14 & $2.44(1 \mathrm{H} ; \mathrm{d} ; 17.4), 2.09(1 \mathrm{H} ; \mathrm{m})$ & 46.16 \\
\hline 15 & $3.92(1 \mathrm{H} ; \mathrm{t} ; 19.7)$ & 67.55 \\
\hline 16 & $1.21(2 \mathrm{H} ; \mathrm{m})$ & 38.46 \\
\hline 17 & $1.89(1 \mathrm{H} ; \mathrm{m}), 2.22(1 \mathrm{H} ; \mathrm{m})$ & 28.87 \\
\hline 18 & $5.41(1 \mathrm{H} ; \mathrm{m})$ & 133.99 \\
\hline 19 & $5.41(1 \mathrm{H} ; \mathrm{m})$ & 126.37 \\
\hline 20 & $2.23(1 \mathrm{H} ; \mathrm{m}), 2.75(1 \mathrm{H} ; \mathrm{d} ; 13.7)$ & 40.69 \\
\hline 21 & $5.30(1 \mathrm{H} ; \mathrm{dd} ; 14.7,11.5)$ & 48.06 \\
\hline $\mathrm{NH}$ & - & - \\
\hline 22 & - & 147.72 \\
\hline 23 & $7.18(1 \mathrm{H} ; \mathrm{s})$ & 120.23 \\
\hline 24 & $7.31(1 \mathrm{H} ; \mathrm{dd} ; 5.04,3.21)$ & 125.82 \\
\hline 25 & $7.10(1 \mathrm{H} ; \mathrm{m})$ & 126.17 \\
\hline
\end{tabular}


Table S9. NMR data of 2-thienyl hitachimycin (H-9).

\begin{tabular}{|c|c|c|}
\hline No & $\delta_{\mathrm{H}}(400 \mathrm{MHz} ;$ multiplicity; $J / \mathrm{Hz})$ & $\delta_{\mathrm{C}}(125 \mathrm{MHz} ;$ multiplicity; $\mathrm{J} / \mathrm{Hz})$ \\
\hline 1 & - & 166.77 \\
\hline 2 & $5.99(1 \mathrm{H} ; \mathrm{d} ; 15.1)$ & 123.46 \\
\hline 3 & $7.24(1 \mathrm{H} ; \mathrm{m})$ & 142.00 \\
\hline 4 & $6.41(1 \mathrm{H} ; \mathrm{dd} ; 11.0,15.1)$ & 127.21 \\
\hline 5 & $7.10(1 \mathrm{H} ; \mathrm{d} ; 15.1)$ & 136.75 \\
\hline 6 & - & 130.99 \\
\hline $6-\mathrm{CH}_{3}$ & $1.89(3 \mathrm{H} ; \mathrm{s})$ & 19.63 \\
\hline 7 & $5.23(1 \mathrm{H} ; \mathrm{d} ; 11.0)$ & 134.48 \\
\hline 8 & $4.07(1 \mathrm{H} ; \mathrm{t} ; 15.6)$ & 34.61 \\
\hline 9 & $2.07(2 \mathrm{H} ; \mathrm{m})$ & 35.01 \\
\hline 10 & $4.50(1 \mathrm{H} ; \mathrm{t} ; 15.6)$ & 80.61 \\
\hline $10-\mathrm{OCH}_{3}$ & $3.53(3 \mathrm{H} ; \mathrm{s})$ & 57.71 \\
\hline 11 & - & 184.93 \\
\hline 12 & - & 112.07 \\
\hline 13 & - & 197.08 \\
\hline 14 & $2.43(1 \mathrm{H} ; \mathrm{d} ; 17.4), 2.07(1 \mathrm{H} ; \mathrm{m})$ & 46.17 \\
\hline 15 & $3.92(1 \mathrm{H} ; \mathrm{t} ; 19.7)$ & 67.41 \\
\hline 16 & $1.16(2 \mathrm{H} ; \mathrm{m})$ & 38.42 \\
\hline 17 & $1.89(1 \mathrm{H} ; \mathrm{m}), 2.26(1 \mathrm{H} ; \mathrm{m})$ & 28.86 \\
\hline 18 & $5.45(1 \mathrm{H} ; \mathrm{m})$ & 134.31 \\
\hline 19 & $5.45(1 \mathrm{H} ; \mathrm{m})$ & 125.83 \\
\hline 20 & $2.26(1 \mathrm{H} ; \mathrm{m}), 2.79(1 \mathrm{H} ; \mathrm{d} ; 13.3)$ & 41.42 \\
\hline 21 & $5.45(1 \mathrm{H} ; \mathrm{m})$ & 47.82 \\
\hline $\mathrm{NH}$ & $7.034(1 \mathrm{H} ; \mathrm{d} ; 10.1)$ & - \\
\hline 22 & - & 145.42 \\
\hline 23 & $7.22(1 \mathrm{H} ; \mathrm{dd} ; 3.66,9.62)$ & 123.94 \\
\hline 24 & $6.98(1 \mathrm{H} ; \mathrm{dd} ; 3.66,8.24)$ & 126.63 \\
\hline 25 & $6.98(1 \mathrm{H} ; \mathrm{dd} ; 3.66,8.24)$ & 123.58 \\
\hline
\end{tabular}


Table S10. NMR data of $(S)-m$-Br- $\beta$-Phe-SA.

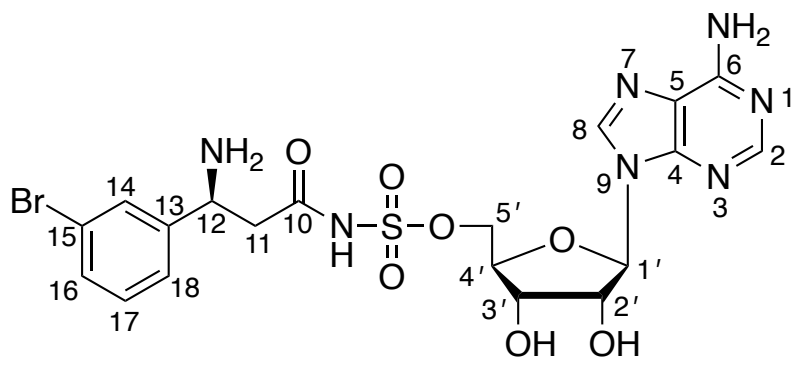

(S)- $m$-Br- $\beta$-Phe-SA in methanol- $\mathrm{d}_{4}$

\begin{tabular}{|c|c|c|}
\hline \multirow{2}{*}{ Entry } & \multicolumn{2}{|l|}{$\delta \mathrm{ppm}$} \\
\hline & ${ }^{1} \mathrm{H}(500 \mathrm{MHz})$ & ${ }^{13} \mathrm{C}(125 \mathrm{MHz})$ \\
\hline 1 & - & - \\
\hline 2 & $8.194(\mathrm{~s}, 1 \mathrm{H})$ & 153.884 \\
\hline 3 & - & - \\
\hline 4 & - & 150.763 \\
\hline 5 & - & 120.180 \\
\hline 6 & - & 157.274 \\
\hline 7 & - & - \\
\hline 8 & $8.510(\mathrm{~s}, 1 \mathrm{H})$ & 141.217 \\
\hline 9 & - & - \\
\hline 10 & - & 177.487 \\
\hline 11 & $2.784(\mathrm{~m}, 2 \mathrm{H})$ & 43.111 \\
\hline 12 & $4.623(\mathrm{~m}, 1 \mathrm{H})$ & 53.385 \\
\hline 13 & - & 14.843 \\
\hline $14 *$ & Major: $7.638(\mathrm{~s}, 1 \mathrm{H})$, Minor: $7.660(\mathrm{~s})$ & 131.460 \\
\hline 15 & - & 123.953 \\
\hline $16^{*}$ & Major: $7.532(\mathrm{~d}, J=7.5,1 \mathrm{H})$, Minor: $7.547(\mathrm{~d}, J=8.0)$ & 133.212 \\
\hline $17 *$ & Major: $7.312(\mathrm{t}, J=8.0,1 \mathrm{H})$, Minor: $7.347(\mathrm{t}, J=8.0)$ & 132.034 \\
\hline $18 *$ & Major: $7.414(\mathrm{~d}, J=8.0,1 \mathrm{H})$, Minor: $7.414(\mathrm{~d}, J=11)$ & 127.161 \\
\hline 1. & $6.071(\mathrm{~d}, J=5.10,1 \mathrm{H})$ & 89.397 \\
\hline $2 !$ & $4.590(\mathrm{t}, J=5.00,1 \mathrm{H})$ & 76.241 \\
\hline $3 !$ & $4.346(\mathrm{dd}, J=4.5,3.0,1 \mathrm{H})$ & 71.980 \\
\hline $4_{-}^{\prime}$ & $4.247(\mathrm{~m}, 1 \mathrm{H})$ & 84.207 \\
\hline $5 !$ & $4.247(\mathrm{~m}, 1 \mathrm{H})$ & 69.012 \\
\hline
\end{tabular}

※ Two signals for probable rotational isomers due to the amide bond was observed. 
Table S11. Structural data collection and refinement statistics.

\begin{tabular}{|c|c|c|}
\hline Dataset & $\mathrm{HitB} / \beta-\mathrm{Phe}-\mathrm{SA}$ & $\mathrm{HitB} / m$-Br- $\beta$-Phe-SA \\
\hline \multicolumn{3}{|l|}{ Data collection statistics } \\
\hline Beamline & PF BL-5A & PF BL-5A \\
\hline Wavelength $(\AA)$ & 1.00000 & 1.00000 \\
\hline Space group & $P 2_{1} 2_{1} 2_{1}$ & $P 2_{1} 2_{1} 2_{1}$ \\
\hline \multicolumn{3}{|l|}{ Unit-cell parameters } \\
\hline$a(\AA)$ & 67.28 & 67.96 \\
\hline$b(\AA)$ & 93.64 & 96.69 \\
\hline$c(\AA)$ & 165.05 & 166.41 \\
\hline Resolution $(\AA)$ & $50.00-2.45$ & $50.00-2.60$ \\
\hline (outer shell) & $(2.55-2.45)$ & $(2.72-2.60)$ \\
\hline Unique reflections & $39,398(4,375)$ & $34,560(4,167)$ \\
\hline Redundancy & $6.1(6.0)$ & $6.6(6.4)$ \\
\hline Completeness (\%) & $100.0(100.0)$ & $99.9(100.0)$ \\
\hline$R_{\text {merge }}$ & $0.107(0.709)$ & $0.089(0.804)$ \\
\hline Mean $<I / \sigma(I)>$ & $13.1(2.5)$ & $17.5(2.5)$ \\
\hline $\mathrm{CC}_{1 / 2}$ & $0.998(0.858)$ & $0.999(0.861)$ \\
\hline \multicolumn{3}{|l|}{ Refinement statistics } \\
\hline$R_{\text {work }}(\%)$ & 21.0 & 21.2 \\
\hline$R_{\text {free }}(\%)$ & 26.0 & 27.0 \\
\hline No. of molecules in the asymmetric unit & 2 & 2 \\
\hline \multicolumn{3}{|l|}{ No. of non-hydrogen atoms } \\
\hline Protein & 7,135 & 7,026 \\
\hline$\beta$-Phe-SA $/ m$-Br- $\beta$-Phe-SA & 68 & 70 \\
\hline solvent & 113 & 64 \\
\hline \multicolumn{3}{|l|}{ Average B-factors $\left(\AA^{2}\right)$} \\
\hline Protein & 53.3 & 63.9 \\
\hline$\beta$-Phe-SA $/ m$-Br- $\beta$-Phe-SA & 39.8 & 51.2 \\
\hline solvent & 42.8 & 49.6 \\
\hline \multicolumn{3}{|l|}{ r.m.s.d. from ideality } \\
\hline Bond length $(\AA)$ & 0.010 & 0.007 \\
\hline Bond angles $\left({ }^{\circ}\right)$ & 1.707 & 1.517 \\
\hline \multicolumn{3}{|l|}{ Ramachandran plot } \\
\hline Favored (\%) & 95.6 & 95.4 \\
\hline Allowed (\%) & 4.2 & 4.4 \\
\hline Outlier (\%) & 0.2 & 0.2 \\
\hline Molprobity clashscore & 4.45 & 4.10 \\
\hline
\end{tabular}

